PONTÍFICIA UNIVERSIDADE CATÓLICA DO RIO DE JANEIRO COORDENAÇÃO DE CURSOS EVENTOS E PROJETOS ESPECIAIS PÓS-GRADUAÇÃO EM LÍNGUA INGLESA

THAIS REGINA SANTOS BORGES

GENDER, IDEOLOGY AND HUMOR IN THE ESL/EFL CLASSROOM 
THAIS REGINA SANTOS BORGES

\section{GENDER, IDEOLOGY AND HUMOR IN THE ESL/EFL CLASSROOM}

Monografia apresentada ao Programa de PósGraduação em Letras da PUC-Rio como requisito parcial para a obtenção do título de Especialista em Língua Inglesa.

Orientadoras:

Professora Juliana Jandre

Professora Doutora Sonia Zyngier

Rio de Janeiro, RJ

Julho 2014 


\section{ACKNOWLEDGEMENTS}

I would like to thank my advisor Juliana Jandre for her immeasurable generosity and kindness when sharing her knowledge and providing me with guidance and support.

I would also like to thank Dr Sonia Zyngier for her wise advice and essential input which helped me start understand what being a researcher entails.

Also, my special thanks to João, my best friend and partner in life, for his crucial help, support and companionship throughout this process and for making me a better person each and every day.

Finally, I thank my father, Hugo Borges, for always being there for me. 


\begin{abstract}
This research focuses on understanding how the use of humor in the ESL/EFL classroom furthers content apprehension in the approach of gender issues. It aims at investigating how teenage ESL/EFL students perceive the underlying gender ideology behind the scenes of sitcoms they are exposed to, analyzing if there are any gendered differences in perception and observing how memorable they can be so as to work as a vehicle to develop language as well as foster critical thinking and feeling in the ESL/EFL class. In order to do so, two scenes of sitcoms widely seen by Brazilian teenagers were chosen, the first being rather more stereotypical of gender than the second. Students of mixed sex groups were exposed to the scenes and marked their opinion on a Differentials Scale devised based on critical discourse analysis and theories of gender and discourse. After 48 hours, students were asked to answer two questions in order to learn how memorable the scenes had been and how effective they can be for raising awareness to gender bias in humor. The findings in this paper will shed a light on the importance of critically choosing exerts of authentic media material to do language work in the ESL/EFL classroom, especially regarding gender ideology.
\end{abstract}

KEY WORDS: humor - gender - critical thinking - feelings - ESL/EFL class 
TABLE OF CONTENTS

1) INTRODUCTION 1

2) THEORETICAL FRAMEWORK 4

1. Humor 4

2. Critical Discourse Analysis 6

3. Gender and Discourse $\quad 8$

3) METHODOLOGY 13

1. Reasoning and execution 13

$\begin{array}{ll}\text { 2. The students } & 14\end{array}$

$\begin{array}{lr}\text { 3. The choice of scenes } & 15\end{array}$

1. First Attempt: How I Met Your Mother 15

$\begin{array}{ll}\text { 2. Final choice: F.R.I.E.N.D.S. } & 18\end{array}$

$\begin{array}{ll}\text { 4. The scenes } & 20\end{array}$

5. The Semantics Differentials Scale (SDS) 23

6. The experiment 26

4) RESULTS AND DISCUSSION 28

5) CONCLUSION

6) BIBILOGRAPHY 


\section{INTRODUCTION}

Technology and globalization walk hand in hand as society develops and grows. In terms of communication and media, we have gained more contact with productions from different cultures and much more access to media products that we would not otherwise have. In this context, media has gained a greater importance in our lives as vehicles that carry information about different possible worlds. As ESL/EFL teachers, we started to find in these productions a great source of samples of sociolinguistic parameters to refer to while teaching language itself.

Since all discourse is ideological (LEMKE, 1995), the discourse we work with in the classroom, through the verbal or visual texts we bring from authentic media, also carry an underlying ideology beneath it. Despite focusing on the language work we may be able to do when choosing this or that media production, it is paramount to investigate what is below the surface of what we have brought to class so we can foster critical thinking as well as language practice.

Gee (1999, p.47) describes this relationship between language and context as "twoway and dynamic" since "we do recognize or assemble situated meanings based on context, but we also construe the context to be a certain way and not another based on the situated meanings we assemble" (GEE, 1999, p.47). Still according to him, we must denaturalize every concept, idea or behavior and take a close look into Discourse (with a capital D) (GEE, 1999), which means:

\footnotetext{
different ways in which we humans integrate language with non-language 'stuff', such as different ways of thinking, acting, interacting, valuing, feeling, believing, and using symbols, tools, and objects in the right places and at the right times so as to enact and recognize different identities and activities, give the material world certain meanings, distribute social goods in a certain way, make certain sorts of meaningful connections in our experience, and privilege certain symbol systems and ways of knowing over others i.e. carry out all the building tasks above (GEE, 1999, p.13).
}

Therefore, understanding these Discourses (GEE, 1999) will go a long way toward understanding roles and expectations when dealing with sociocultural aspects of language. 
Having said that, ESL/EFL teachers do tend to focus very much on language development insomuch as the context and the Discourse (with a capital D) (GEE, 1999) is secondary, if not completely ignored. As a result, the ESL/EFL classroom, which could work as a place for students' and teachers' personal and intellectual growth as well as improving language competence, becomes void of meaning and thought-provoking debates. It is essential that ESL/EFL teachers understand that language is a sociocultural expression and must be addressed as such in order to be truly faithful to what students' will need and face beyond the limits of the classroom. Similarly, the ideologies that surpass discourse, or the many Discourses (GEE, 1999) are to be dealt with in the ESL/EFL classroom in order to deepen the understanding of hidden agendas in media pieces used by ESL/EFL teachers in class.

In this light, this work is an investigative analysis of what is behind the ESL/EFL students' laugh as to how they may perceive the underlying ideology regarding gender issues when exposed to scenes from a sitcom they usually watch for fun in their daily routines and for furthering their language knowledge in the ESL/EFL classroom. Along these lines, the research analysis aims at answering the question "What is behind the laughter in the ESL/EFL class?" in an attempt to further the understanding of how media used in the ESL/EFL class works as a way to bring about a broader issue such as gender bias.

More specifically, this research provides an account of how a sample of teenage ESL/EFL students, male and female, felt regarding the problematic or naturalized representation of gender in two scenes from the sitcom series F.R.I.E.N.D.S.

In order to collect data, an experiment was devised by creating a semantics differentials scale which was marked on by the participants while watching the two different scenes. After forty-eight hours, students were asked to report on their favorite scene in order to verify whether they retained anything they had watched, with the intent of verifying the hypothesis that students probably do assimilate what they see and that humor can indeed work as a means to ease critical thinking into the classroom, besides the language development aimed by the ESL/EFL teacher when presenting such media samples. Thus, the experiment proposed was meant to work as a tool to see whether it is possible to draw opportunities to raise students' awareness towards more complex issues regarding gender representativeness and roles by showing these humorous acts in class. 
The choice for working with a sitcom came from the desire to investigate material that ESL/EFL teachers are increasingly using in class when exploring language, mainly when they intend to show 'real-life-like' spoken English material, as these samples tend to mimic the way people talk and act in a rather natural way and represent a little of the pop culture of an English speaking country. Moreover, sitcoms invariably work as vessels for ideological agendas, specifically those concerning the naturalization of gender roles and representations. Besides that, using something which is already present in the ESL/EFL learner's life as a means of entertainment, such as comedy series, makes it easier to reach them and raise the questions needed to investigate their perceptions on any issue, including those regarding gender ideology.

In summary, the interest and relevance of this paper lie in the contribution this analysis makes as a qualitative sample of how ESL/EFL students may perceive the hidden agenda of gender ideology in sitcoms they are presented with in the ESL/EFL class. Furthermore, this work will add to the debate surrounding the importance of including critical thinking in the ESL/EFL class and how ESL/EFL teachers can ease it into the classroom though means of humor and entertainment.

The theory that worked as the backbone of this analysis was that which corroborates the importance of using humor in the ESL/EFL class not only for building rapport but also for better language apprehension (WANZER, 2002) and gender ideology studies, especially those concerning feminist linguistics. The latter worked as parameter for content analysis, as opposed to discourse analysis, and was crucial when choosing how to develop the experiment, particularly when choosing the scenes to work with in order to unveil the gender ideology hidden behind the funny plots lived by the characters. Very briefly, Gee's disposition about sociocultural linguistics and critical discourse analysis was also taken into consideration, more specifically in justifying the reasons behind choosing the research line.

As follows, the theoretical framework that guided this analysis shall be exposed first. Then, the methodology used in the experiment will be detailed so that a meaningful analysis of the subject approached in this paper may be conducted. Finally, there are some final considerations regarding the results found and the conclusions reached by means of this research. 


\section{THEORETICAL FRAMEWORK}

The aim of this research is to analyze how gender roles and representativeness are depicted in humorous media samples watched by teenage ESL/EFL students in Brazil on their day-to-day, in an attempt to help ELS teachers use humor in the classroom to foster critical thinking regarding gender issues. Bearing this in mind, it is necessary to understand how humor and learning relate to each other and which benefits the learner can have from this relation. The fact that teenage students are now in touch with authentic comedy material from native English speaking countries on a regular basis, thanks to the internet and technological advances, has brought a new dimension to the necessity of understanding how much benefit students can have from dealing with such materials. It is paramount to raise teachers awareness to the impact they may have in the classroom, by helping teenage students not only develop their language skills but also grow up as critical human beings. The first section of this chapter aims at discussing how humor has played an important role in ESL/EFL teaching/learning. The second section refers to critical discourse analysis as a means to analyze content and the last part discusses gender and discourse in order to shed a light on the reasoning that guided this research.

\subsection{HUMOR}

The use of humor in the classroom has been widely discussed and a series of investigative studies have been done in order to pinpoint benefits and its relation with affect, effectiveness and effect on the learner. As a general rule, it is correct to assume humor does help improve learning, although when questioning if humor "always promote learning in the classroom" the answer "is NOT an unequivocal yes", mainly because many different aspects will influence the "humor-learning relationship" and it's impossible to draw an isolated conclusion, according to Wanzer (2002, p.118). It is clear however, that humor benefits the learner because it helps improve rapport, to say the least (WANZER, 200, p.117). 
Using humor in the classroom may be quite challenging though, because it may be difficult for teachers to find humorous situations in the classroom activities themselves, as Gilliland and Mauritsen (1971) observe. That is an interesting aspect this research responds to, as by making use of students' own habits of watching humorous acts in the media, the teacher can understand a bit better what they have at hand and try to incorporate it conscientiously into their class, helping students develop their skills as well as their critical thinking. Still according to Gilliland and Mauritsen, by making use of humor, teachers can provide students with a light atmosphere, more suitable to foster confidence and trust among the parts involved, "narrowing the gap" (GILLILAND \& MAURITSEN, 1971, p.755) between them and having students see humor is actually welcome in the classroom. Moreover, not only is humor seen as a tool to help students learn, but learning how to fit humor into everyday situations can also become an asset for life, preparing them for moments that would be otherwise "devastating", as Gilliland and Mauritsen state (1971, p.754),. This is a crucial point as it connects directly with the notion of using the ESL/EFL class as a means to promote learning in a more thorough sense, fostering critical thinking which is something students can take with them as they cross the classroom door.

This realization that humor can be beneficial in the classroom environment brings us to another important point which is the appropriateness and the effectiveness of the choices we make in the classroom regarding material and behavior. Something we all should concentrate on before we start exploring the many possibilities laid out in front of us is to understand how the humor-learning dynamics happen between teachers and students, according to Wanzer (2002) and understand how humor itself operates as vehicle for discourse and a means for language work in the ESL/EFL classroom. In order to ensure learning takes place effectively, we must observe the effect humorous acts have on students and analyze how teachers and students, who most likely come from different backgrounds, perceive such acts. For instance, some teachers may be more oriented to humor than their peers, or students, and present high or low "humor orientation", as mentioned by Wanzer (2002, p.119). This should influence directly the choices teachers make and the effectiveness of certain strategies and materials used with certain students. Still regarding how appropriate materials are, studies reported by Wanzer (2002) suggest that some topics are definitely inappropriate in the classroom such as "humor that singles out or belittles a particular student" (Wanzer, 2002, p.122) or "sexual and stereotypical humor", especially regarding women as it 
may "lead to sexual harassment complaints" (2002, p.123). The latter observation is quite peculiar and interesting for this research as it reinforces the need to raise students' and teachers' awareness toward thinking critically about the importance of denaturalizing some gender biased behaviors in our pop culture humor.

As many studies about humor tend to confirm, the use of humor does benefit students learning process and it is important to note that, in terms of content, "both related and unrelated humor can be effective in the classroom" for different reasons (WANZER 2002, p.122). The former is beneficial due to its effectiveness in terms of learning itself and the latter because it works as "ice-breaking or affinity-seeking strategy" (WANZER 2002, p.122). Either way, students and teachers can benefit from using humor in the classroom as long as some parameters are observed concerning how appropriate and effective it will be in order to foster learning. Since the understanding of ESL/EFL learning goes beyond the limits of the classroom and encompasses what students take with them besides language itself, this research aims at expanding the scope of investigation of the use of humor in the classroom. Its focus on authentic material and the analysis of gender roles and representativeness in comedy series (or film), adds to the pool of studies of humor in the classroom and it goes further by adding critical thinking to the equation.

\subsection{CRITICAL DISCOURSE ANALYSIS}

Discourse is used in reference to a "broad system of meaning" and to "knowledge and practices generally associated with a particular institution or group of institutions", according to Talbot (1995, p.43, apud SUNDERLAND, 2006, p.48). In dealing with discourse and critical discourse analysis it is important to understand the concept of "Discourses with a capital D" (GEE, 1999, p.13), which covers:

[the] different ways in which we humans integrate language with non-language 'stuff', such as different ways of thinking, acting, interacting, valuing, feeling, believing, and using symbols, tools, and objects in the right places and at the right times so as to enact and recognize different identities and activities, give the material world certain meanings, distribute social goods in a certain way, make certain sorts of meaningful connections in our experience, and privilege certain symbol systems and ways of knowing over others" (GEE, 1999, p.13) 
It also covers semiotics as "what and how different symbol systems and different forms of knowledge “count” (GEE, 1999, p.13).

Along these lines, Gee (1999) calls the different identities that operate in order to communication to take place "Discourses with capital D". It includes all forms of meaningmaking. By that, Gee (1999) means that it is not only language in use itself, but language plus values, beliefs, attitudes, cultures, behaviors and many other variables that should be taken into account. Discourses can be defined as "connected sets of statements, concepts, terms and expressions, which constitute a way of talking about or writing about a particular issue, thus framing the way people understand and act with respect to that issue" (WATSON, 1994, p.113). As follows,

\footnotetext{
'the key to Discourses is recognition.' If you put language, action, interaction, values, beliefs, symbols, objects, tools, and places together in such a way that others recognize you as a particular type of 'who' (identity) engaged in a particular type of "what" (activity) here and now, then you have pulled off a Discourse (...)" (GEE, 1999, p.18).
}

In this research, it is essential to understand the "constitutive nature of discourse" (SUNDERLAND, 2006, p.49) which renders discourses as "potentially constitutive systems of meaning" and "different ways of structuring areas of knowledge and social practice" (FAIRCLOUGH, 1992, apud SUNDERLAND, 2006, p.49). This "constitution can be symbolic, semiotic and/or discoursal, but is also potentially material and social, i.e. constituting effects beyond discourse" (SUNDERLAND, 2006, p.50). Though its effects may be limited, it is still worth acknowledging its significant potential especially in regard to the stereotypical gender representation in the media in order to understand how gender ideology makes out for a hidden agenda underlying humorous acts ESL/EFL teachers bring to class either reinforcing it or allowing questioning.

The concept of intertextuality also plays an important role as "a given discourse is always related to others, both synchronically and diachronically" (SUNDERLAND, 2006, p.52). The concept of "interdiscursivity" or the "mixing together of different discourses and genres" (FAIRCLOUGH, 1992, apud SUNDERLAND, 2006, p.52) also adds to that because in using different media when approaching matters of gender, Discourses will intertwine and "continually take on characteristics of each other, endlessly combining and recombining" (SUNDERLAND, 2006, p.52) demanding more critical thinking and an increase in awareness in order to allow the audience to fully grasp what is below the surface of what they have at 
hands. In this research, when analyzing students' perception of the sitcom scenes, the plot was meant to work as the basis for an analysis with focus on the ideological agenda and its many discourses concerning gender relations.

\subsection{GENDER AND DISCOURSE}

Critical Discourse Analysis (CDA) deals with gender representation in written text and talk by means of "subject positioning" (SUNDERLAND, 2006, p.53), literally in terms of where subject and object stand in the sentence and more subjectively in terms of who is subjected to whom, as Sunderland explains (2006, p.53). According to her, "the representation and construction of gender in text and talk" is gendered in itself, "idiosyncratic or normative, conservative or progressive" and even though reality may differ from what is represented, it is not rare to see people "taking up [or not] to particular 'gendered subject position"” (WETHERELL, 1998; WEATHERELL, 2002, apud SUNDERLAND, 2006, p.53). This is specifically interesting in this research since the scene portraying a more stereotypical view of gendered behavior highlights this aspect of the female agenda being subject to that of "her man's", illustrated by Rachel deciding to quit pursuing her career in order to stay with Ross and her family, as he had wished all along.

The determinist view that "gendered discourse always constructs [as opposed to construes] gender [or that a particular stretch of discourse does so]" is usually overestimated and not sustained by evidence (Sunderland, 2006, p.54). Along these lines, the idea that "something that is gendered can also be gendering" (Sunderland, 2006, p.54) must be investigated further in CDA as "individual agency and the possibility of resistance" play a big role in determining if people accept, recognize or reject sexist discourse. This concept is central to this research as the whole investigation is focused on the perception of teenage ESL/EFL students regarding sexist stereotype and questioning of gender roles.

Having said that, it is important to note the most recent approach to gender as a "sexcorrelate" (SUNDERLAND, 2006, p.28) as it taps into what this analysis aims at investigating. The idea that biologically, males and females have certain "culturally imbued characteristics which fall neatly into the same two biologically determined categories" 
(SUNDERLAND, 2006, p.28) echoing the notion of "(appropriate) sex-roles" (SUNDERLAND, 2006, p.28) is specifically interesting here as it comprises the notion that sex-roles/gender-roles are "learned" by boys and girls, still according to Sunderland (2006, p.28). If that really is the case, then expectation towards exceptional behavior would be that people would probably recognize it and accept or reject it based on their own agency as mentioned previously. This analysis aims at determining if this actually happens, and how it does among male and female teenage students, within and between the groups, so as to optimize the chances of building on it to foster critical thinking.

As a side note, in fact there are three major ways to approach this sex-gender relationship, according to Sunderland (2006, p.28). "First, that gendered behavior is 'built on' to pre-existing sex differences" as mentioned before. "Second, that the sex-gender relationship may be arbitrary, but that there will always be gender differences in behavior, which then come to "symbolize sex"”, still according to Sunderland (2006, p.28), which questionably implies an imposition of a certain behavior over men and women due to their biological attributions, as explained by Nicole-Claude Mathieu (1989, 1996, in: Sunderland, 2006, p.28)

However, as Sunderland points out, there are more complex ways to discuss gender nowadays and a third view would be that of gender as "conceptually dissociated from actual 'sexed individuals' completely" (SUNDERLAND, 2006, p.28) and seen "entirely as a set of articulated ideas about girls and boys, women and men, individually or collectively" (SUNDERLAND, 2006, p.28).

In summary, the purpose of this research is to shed a light on how teenage boys and girls perceive gendered behavior and gender representation, with special focus on the first two concepts of gender perception. By measuring how accepting they are of stereotypes and how naturally they see sex-role inversion, it will be possible to analyze their expectations towards "male behavior" and "female behavior", especially regarding what is perceived as feminine or masculine.

As the scenes used in the experiment were meant to express feminist concerns of the semiotics of gender role representation and gender bias, it was important to understand the feminist critique of discourse analysis, namely feminist linguistics. Even though there was no linguistic analysis performed in this research, the guidelines to understand issues in gender 
representation and stereotype were developed on the basis of feminist critique parameters. As the plot in the two scenes were expressions of gender roles and representativeness both under a stereotypical perspective and that of challenging expectations, it was decisive to understand what had laid the ground for understanding gender ideology in feminist linguistics, so a parallel with the semiotic choices in media could be traced.

At the level of language, "the words available to us to describe women and men are not the same words" and "gender distinctions are built into language", as Tannen (1991, p.121) points out and adds that "simply by understanding and using the words of our language we all absorb and pass on different, asymmetrical assumptions about men and women”. What is interesting though is that when it comes to using another modality of text, that of media, the possibilities of portraying men and women in various ways are infinite and yet stereotypical representation seem to still be the rule, as many studies in many different fields show. In a broader sense, the "asymmetrical assumptions" mentioned by Tannen (199, p.121) could also be translated into the relation between the audience and the writers/producers of series and movies when taking into consideration the greater circle of influence that encompasses language through its sociocultural aspects, as mentioned by Gee (1999, p.13).

In this research it became clear that the audience interacts and reacts differently to certain aspects of gender representation, subverting assumptions concerning gendered opinions and interpretation. Male students and female students seemed to respond quite differently to certain points of gender bias in the sitcom they watched, yet very similarly to others. In this sense, it is paramount to understand what the premises of stereotypical representation are, how far they can reach and how the same audience reacts to this attempt to win them over through humor, in regard to their gender ideology awareness.

Still at the language level, a gender study on language variation among social groups aiming at answering "why stigmatized varieties persist" in regard to gender, Finnegan (2011, p.379) concluded that "differences between male and female in language have little to do with biological sex and a lot to do with socially constructed gender roles". That was designated "sociocultural phenomenons of gender". Even though Finnegan focused more on aspects of prosody and language itself, the study is relevant here because it foregrounds the importance of analyzing gendered responses and actions in a wider context of sociocultural aspects, which is exactly what this research aimed at. 
Under the feminist critique umbrella, many different approaches and attempts to understand how men and women use language have been put forward. From Robin Lakoff's (1973) "deficit approach", pioneer in questioning women's position and place in society with focus on power and an idea of subordination from women towards men, then on to Dale Spender's "dominance approach", which argued that "theories and categories are not genderneutral" (SUNDERLAND, 2006, p.14) and through sexist language and culture sexism is perpetrated and reinforced as "observation of reality is also likely to be sexist" (SPENDER, 1980, apud SUNDERLAND, 2006, p.14), and later on to the "(cultural) difference approach" with Daniel Maltz and Ruth Borker's claims that since men and women are brought up in different cultures, divergences between them in conversation could be compared to "problems between people of different ethnic groups" as they "are the result of differences in systems of conversational inference and the cues for signaling speech acts and speaker's intent" (MALTZ \& BORKER, 1982, apud SUNDERLAND, 2006, p.19).

In general terms, though the difference approach can be seen as a moment of "feminist celebration, reclaiming and revaluing women's distinctive cultural traditions" (CAMERON, 1995, apud SUNDERLAND, 2006, p.20), it can also be criticized by showing women's talk as being "deficient language users" or "victims" as Jennifer Coates observes in her positive evaluation of all-women talk in her 1989 "Gossip revisited" (COATES, 1989, apud SUNDERLAND, 2006, p.20). Nonetheless, the difference approach bears close resemblance to the dominance approach and both "can be seen in one sense as anti-feminist with their socially essentialist focus on the binary nature of gender" (SUNDERLAND, 2006, p.22) and it failing feminism in a way as "every word we say on the subject of difference just underlines the salience and the importance of a division we are ultimately striving to end", according to Cameron (1992, apud SUNDERLAND, 2006, p.22). Along these lines, the current concept of gender and the feminist agenda focus on the "notion of gender as a construct, or idea, dissociated from dimorphically sexed human beings" and relations of power and differences should be taken into consideration in a much broader sense.

Another point is that "portrayals are broadly synonymous with representation", as Sunderland (2006, p.25) suggests and "gender representation is often achieved through stereotyping", which is the focus of the experiment devised to understand how students perceive gender bias. As "many representations seem to put women at a disadvantage", she continues, "there is always the need for interpretation of a given representation, as "what is 
happening' (...) may be seen differently by one person and by her or his friend" (Sunderland, 2006: 25). In this sense, the experiment devised in this research comes to help investigate a bit further how differently teenage boys and girls perceive these stereotypes.

As meaning is "co-constructed, that is, not only by the text (and its producer), but also by the 'consumer' (the reader or listener) (...) to talk about an 'effect' of any given representation (whether in fiction, on television or in a political speech) is always problematic" (Sunderland, 2006: 25).

No matter how challenging it may be, it is still rather important to go further in these studies in order to develop understanding, awareness and critical thinking.

Bearing this in mind, the understanding of gender representation and the feminist critique was paramount to put together the scenes that allowed the observation and identification of a stereotypical gender representation and a problematized version, creating a contrast to check students' perception of gender bias in the media. Even though there was no linguistic analysis taking place, the very understanding of gendered discourse and ideology was essential to form the tangle of problems that were put to test in the experiment. These problems will be further explained in the Methodology chapter. 


\section{METHODOLOGY}

This chapter will detail how the analysis was carried out. It provides a general overview of the implementation of the experiment including an overview of the participants, a detailed description of the instruments used such as the semantic differentials scale and the selection of scenes. The objective of this chapter is to provide a clear explanation so that other teachers and researchers may further investigate the area of the use of humor in the ESL/EFL class.

\subsection{REASONING AND EXECUTION}

As indicated in the research questions proposed in this paper, this analysis aims at understanding if students actually find the snippets we show them in class funny; how much sexism they notice in such scenes, if any at all, and if they remember the scenes long enough in order for it to have an impact in their perception of sexism or in their forwarding a gendered biased commentary. The aim of this research is to try and unravel the impact ESL/EFL teachers' choices have on students not only in the classroom but also outside its walls.

In order to do so, students were asked to identify which sitcoms they themselves liked watching daily Even though many times teachers present students with the scenes they pick themselves, for the purpose of this investigation it would be much more meaningful if, instead of bringing some random comedy act for them to see, they were exposed to something they were already keen on watching. Also, due to the nature of this research, it was also very important to choose a sitcom that both male and female students liked watching, to avoid bias towards this or that group. Finally, the age group was important to be defined as a more mature audience would be more proficient to deal with the subject in English.

Bearing this in mind, the experiment was devised by dividing students into two groups who would watch two different scenes from the same sitcom. First, a semantic differentials scale was created with adjectives which could translate student's perception (or 
lack thereof) of sexism together with their feeling of amusement and entertainment, when that was the case. This scale was used by students in order to limit their range of choice when qualifying the scenes as well as facilitate the checking of certain variables and maintain focus on the topic under investigation. All the adjectives in the scale bore a connection with the idea of how funny or sexist the scenes might have been.

Both scenes came from the same sitcom, chosen after researching students' preferences so that they depicted two different angles concerning gender roles and representation. One scene had a more stereotypical take which agrees with the naturalization of sexism and the other problematized this very naturalization of gender biased representation by playing and ridiculing preconceived ideas of stereotype. They were presented to the two distinct groups of students, one scene at a time, on the same day, and they were asked to express their opinions on the differentials scale. In order to neutralize possible bias in the results, the first group of students watched the problematic scene first and then the stereotypical one and the second group had this order inverted: they watched first the stereotypical scene and then the problematic one. After they had marked their preferences on the scale, the differential scales containing their opinion were collected and the results sorted out.

Forty-eight hours later, students were asked to answer a questionnaire about what they had watched in order to see how much they actually remembered from the scenes and which scene they found funnier and why. This time they answered in a rather freer way, in their own words. The objective of this second round of questions was to see how much of the scenes they in fact retained and thus if it is worth using the scenes as a hook to foster critical thinking in the ESL/EFL class especially in matters of gender.

\subsection{THE STUDENTS}

They were all upper-intermediate/advanced level students, English level of B2/C1, according to the Common European Framework of Reference for Languages and therefore proficient for the purpose of the research. Although there were 41 students in total, 21 Upperintermediate students and 20 advanced level students in total, only 36 participated the second 
part of the experiment by answering the open-ended questions 48 hours after marking their opinion in the Semantic Differentials Scale. They were 20 boys and 21 girls varying in age from 15 to 18, with five exceptions: two 13 year-old boys and three 14 year-old boys. As their answers did not differ much from their peers their answers were taken into consideration.

All the students belonged to different classes from different teachers, mine included. None of them knew beforehand what the experiment was about or what the aim of the survey was.

\subsection{THE CHOICE OF SCENES}

\subsubsection{First attempt: How I Met Your Mother}

To start with, a survey (see Table 2) was run among an upper-intermediate/advanced level group with boys and girls aged between 15 and 18 years old in order to find out their taste for sitcoms and/or comedy movies/acts. At this early stage in the research there was still some doubt between working with sitcoms or films, so the questionnaire was a bit too long, and was improved in the next attempt to investigate sitcoms specifically.

Table 2

\begin{tabular}{|c|c|}
\hline & NAME: ___ LEVEL:___ AGE: __ \\
\hline & What makes you laugh? \\
\hline & $\begin{array}{l}\text { Do you watch any comedy series in English? ( ) yes ( ) no, because } \\
\text { If so, which ones? 1) } \\
\begin{array}{ll}\text { 3) } \\
\end{array}\end{array}$ \\
\hline & $\begin{array}{l}\text { Have you watched any comedy movies recently that you really enjoyed? ( ) yes ( ) no } \\
\text { If so, which one(s)? }\end{array}$ \\
\hline & Why did you like it (them)? \\
\hline & $\begin{array}{l}\text { Name the top } 3 \text { comedy movies of all time in your opinion (tittle in English or in Portuguese) } \\
\text { 1) } \\
\text { 2) } \\
\text { 3) }\end{array}$ \\
\hline
\end{tabular}


The problem with this questionnaire was that it was not straightforward enough and some students felt confused when justifying why they liked the movies/series they chose. Another point was that the focus was much more on movies than series and analyzing movies could develop into a much more counter-productive activity since it is a much broader universe than that of sitcoms. By collecting their answers it was clear that the options of films varied enormously and rarely repeated themselves, allowing for too many possibilities. On the other hand, from the 24 students who answered the first questionnaire, many of them mentioned the same series, as seen in Table 3, indicating this would be a much more reasonable choice to work with, allowing for a more enjoyable experience for students' and higher chance of success for the experiment itself, as more students' would connect to the scenes simultaneously.

Table 3

\begin{tabular}{|c|c|c|c|c|c|c|}
\hline Gender & Age: 15 (11 students) & sts & Age: 16 (8 students) & sts & Age: $17-18$ (5 students) & sts \\
\hline \multirow[t]{6}{*}{ MALE } & Friends & 1 & Friends & 4 & Friends & 2 \\
\hline & How I met your mother & 2 & How I met your mother & 3 & How I Met Your Mother & 2 \\
\hline & Seinfeld & 1 & The Big Bang Theory & 2 & Monty Python's Flying Circus & 1 \\
\hline & The Big Bang Theory & 3 & Two and a half men & 2 & & \\
\hline & Two and a half men & 3 & & & & \\
\hline & No series at all & 0 & No series at all & 0 & No series at all & 0 \\
\hline \multirow[t]{6}{*}{ FEMALE } & Friends & 2 & 2 Broke Girls & 1 & Friends & \\
\hline & Glee & 4 & Friends & 4 & Glee & \\
\hline & How I met your mother & 1 & Glee 4 & 4 & How I met your mother & \\
\hline & & & How I met your mother & 1 & & \\
\hline & & & New Girl & & & \\
\hline & No series at all & 0 & No series at all & 1 & No series at all & 0 \\
\hline
\end{tabular}

Something intriguing this time was the fact that only one student said she didn't watch any series whatsoever. As the table shows, Glee seemed to be very popular among girls and The Big Bang Theory and Two and a Half Men, among boys. However, only two series depicted in both male and female choices: Friends and How I Met Your Mother (HIMYM).

Although Friends is considered to be a pioneer in its segment and a classic among all-time sitcom lovers according to specialized magazines and websites, it has been off-air since 2004. Therefore, HIMYM initially seemed to be the most appropriate choice for the experiment as it would probably be more interesting to work with a series which was more 
up-to-date. However, as the process of trying to find an appropriate scene unfolded, it became clear that choosing a scene from a series from such a sitcom would have its downsides, such as unfamiliarity with characters and their nuances.

HIMYM tells the story of a man who is telling his children about how he met their mother when he was in his 20's. The series focuses on this person, Ted Mosby, and his four friends, females Lily and Robin and males Barney and Marshal. In the group, Lily and Marshal are married and have been so since college, where they met Ted. Barney and Robin are single and, in theory, they do not ever want to get married - which is dismissed as they marry each other in the season finale.

Never having watched any HIMYM episodes and aware of the fact there have been 9 seasons in total, adding up to a total of 208 episodes from which only two scenes would have to be chosen, the best option was to start reading about the series online to understand the characters so as to decide which characters would be more suitable to focus on before focusing on specific scenes.

On the internet, many feminist blog writers had shared their opinions on the series, suggesting it was rather sexist at times, despite some female friendly aspects. According to them, although the women main characters on the show, Lily and Robin, were mostly portrayed as upfront, independent and freer, "in a more positive feminist light than on other popular sitcoms" (see the f word - http://goo.gl/gzsMW4), in many cases they were perceived as caricatures of men, as cool "not because they are actually cool but because they act like their male friends" (see feminist media - http://goo.gl/Wyk3Pv), especially in reference to Robin, who is portrayed as a woman who struggles to get along with other women (see feminist fiction - $\underline{\mathrm{http}}$ //goo.gl/WZd01w). Another point the bloggers made was in regard to one specific character, Barney, who is openly sexist but tends to get the empathy of the audience, which some of them dared call "cuddly sexism" (see maybe genius http://goo.gl/6kSGBL) going as far as concluding that "the fact that this character is so popular is a wonderful example of rape culture" (see feministing.com - $\underline{\mathrm{http}} / / / \mathrm{goo} . \mathrm{gl} / \mathrm{R} 4 \mathrm{qlYh}$ ). That was so intriguing that it became only natural to take the next step and watch some episodes with special focus on this specific character, Barney, and the women, Lily and Robin. 
While searching for scenes, some positions of the characters seemed rather questionable indeed and finding a scene that was relevant, funny and yet non-sexist or whose entertainment came from something either than a sexist take on a given situation or joke became a real challenge. This may have happened because of the bias from the blogs or maybe because the show really does lack creativity, originality and therefore humor. Either way, working with HIMYM had become unreasonable at this stage. As a result, according to the questionnaire that had been run among the students, Friends became an option again.

Reading online about sexism on Friends there were far fewer comments mentioning sexism in the series and in fact there were a few blogs actually complimenting the feminist side of one character specifically, Rachel Green (see T.SHE Unpacking Television from a Feminist Perspective http://goo.gl/2ryKKZ and $d r$ she bloggo - http://goo.gl/A0LmpF). However, another website which specializes in matters of masculinity pinpoints examples of "hyper-masculinity" (see theorizing masculinity http://goo.gl/RZm7DR).

\subsubsection{Final choice: F.R.I.E.N.D.S}

F.r.i.e.n.d.s is about a group of 20 -and-so year-olds struggling with relationships and work but instead of 5 people, like in HIMYM, there are six, three male characters - Ross, Chandler and Joey - and three female ones - Rachel, Monica and Phoebe. Although some aspects of the series are still quite bluntly biased, like the characters' jobs which are typically male/female related (e.g. Ross is a University professor, Chandler is an executive and Joey is an actor, whereas Rachel, Monica and Phoebe are a waitress/a Fashion Industry employee; a chef and a masseuse, respectively) and how obsessed with getting married all the girls become as opposed to the guys, in general terms there is a bit more balance in terms of the jokes and idiosyncrasy of each character.

In order to make sure F.ri.e.n.d.s was really so widely accepted among students at the target age and level, another quick, straightforward survey was run. With the help of other teachers, students answered to a brief questionnaire (see Table 4) from 73 UpperIntermediate/Advanced level students between 15 and 18 years old, with a few exceptions, at Cultura Inglesa. 
Table 4

\begin{tabular}{|l|l|}
\hline ( ) MALE $\quad$ AGE: $\quad$ FEMALE & AG_LEVEL: \\
\hline Name three COMEDY series you like watching: & $1)$ \\
& $2)$ \\
& $3)$ \\
\hline
\end{tabular}

The result (Table 5) came to confirm their preference for F.r.i.e.n.d.s.

Table 5

\begin{tabular}{|c|c|c|c|c|c|c|}
\hline Gender & AGE: 15 (29 students) & \#sts & AGE: 16 (33 students) & \#sts & AGE:17-18 (11students) & \#sts \\
\hline \multirow[t]{13}{*}{ MALE } & Adventure Time & & Breaking Bad & & American Dad & \\
\hline & Breaking Bad & & Friends & 8 & Family Guy & 34 \\
\hline & Drake and John & & How I Met Your Mother & 5 & Friends & 3 \\
\hline & Friends & 9 & Seinfeld & & How I Met Your Mother & 2 \\
\hline & How I Met Your Mother & 4 & South Park & & Modern Family & \\
\hline & Monty Python & & The Big Bang Theory & 4 & Suborgatory & \\
\hline & Seinfeld & & Two and a Half Men & 3 & The Simpsons & 2 \\
\hline & South Park & & The Office & & Two And a Half Men & 4 \\
\hline & That 70's Show & & The Simpsons & 2 & The Big Bang Theory & 3 \\
\hline & The Big Bang Theory & 3 & Workaholics & & & \\
\hline & Two Broke Girls & & & & & \\
\hline & Two and a Half Men & 5 & & & & \\
\hline & The Simpsons & 2 & & & No series at all & 1 \\
\hline \multirow[t]{16}{*}{ FEMALE } & Awkward & & Family Guy & & Friends & 2 \\
\hline & Friends & 11 & Friends & 17 & Grey's anatomy & \\
\hline & Get Smart & & How I Met Your Mother & 8 & How I Met Your Mother & \\
\hline & Glee & 2 & Glee & & Two and a Half Men & \\
\hline & Gossip Girl & & Modern Family & 5 & The Big Bang Theory & \\
\hline & How I Met Your Mother & 5 & Two Broke Girls & 2 & & \\
\hline & I Dream Of Jeannie & & The Big Bang Theory & 10 & & \\
\hline & Mom & 2 & Two And a Half Men & 5 & & \\
\hline & Modern Family & & New Girl & & & \\
\hline & New Girl & & Miranda & & & \\
\hline & The Big Bang Theory & 16 & Mom & 2 & & \\
\hline & The Middle & 2 & The Middle & 2 & & \\
\hline & Two Broke Girls & 2 & The Simpsons & 1 & & \\
\hline & Two and a Half Men & 4 & Carrie's Diary & & & \\
\hline & The Simpsons & 2 & Vicious & & & \\
\hline & The White Queen & & No series at all & 1 & & \\
\hline
\end{tabular}


As expected, both F.r.i.e.n.d.s and HIMYM were mentioned by all groups of students. Interestingly enough, this time there were two series which also widely appeared in the answers which had had minor significance in the previous survey: Two And a Half Men and The Big Bang Theory. As the idea behind this second round of questions was to help decide between F.ri.e.n.d.s and HIMYM, the significance of the former two series was deliberately ignored. By looking at Table 5, we can conclude that even though F.r.i.e.n.d.s seems to be more popular among teenage girls, it is still considerably popular among teenage boys.

Due to the struggle in finding the most appropriate episode of HIMYM and the overwhelming results of the survey pointing to the still great popularity of the sitcom F.r.i.e.n.d.s, the latter was chosen. In order to maintain the idea of working with something more recent, the seasons used were the latest two: Season 9 and Season 10. As there are 42 episodes all in all, it was not unreal to watch them in search for a relevant topic that would suit the purpose of this research.

\subsection{THE SCENES}

When watching the episodes, the initial thought was to choose two scenes of around 2 or 3 minutes each. However, for the sake of the experiment it was changed for two "plots", which involved a combination of scenes regarding the same characters and the same motivation throughout an episode. The more the episodes revealed themselves, the more it made sense to show students the whole situation involving the characters in the scenes so they could really grasp where it all came from and be able to make an informed decision as to how they felt about the character's behavior in that specific situation. As the survey showed, students are very familiar with the characters and may have some expectations toward each one of them. That is why it would be interesting to provide them with as much circumstantial information as possible so they could judge the scenes based on that specific behavior, as opposed to the character's history. In other words, there was no point in them judging Joey, or Ross, or Chandler, for instance. They were meant to judge their attitude, their ways, in that specific sexist/funny context.

The episodes chosen reflect two different perspectives towards gender roles and representation. The first one is a snippet of Episode 06 in Season 09, "The one with the Male 
Nanny". As the tittle of the episode very well summarizes, this episode has actor Freddie Prinze Jr as a guest playing Sandy, a male nanny. After interviewing a series of candidates and struggling to find the perfect nanny for their daughter, Ross and Rachel interview Sandy, who is flawless in each and every way, except for Ross who cannot get passed the fact he is a man. Ross and Rachel's plot in the episode is about their search for the ideal nanny, which is clearly not an easy task to do and Ross making it even more difficult by not accepting Sandy as their perfect choice simply because being a nanny is "not what guys do". Rachel is in love with their new hire and even Joey, who is a typical "men's man" in the show, seems to be enjoying his time around such a smart, sensitive person as Sandy. The whole story unfolds in a way that Sandy ends up losing his job, about which he is completely fine because of the many other job offers he has always had for being such a good, well-prepared professional. Ironically, it is Ross who ends up crying like a baby about past issues which come to explain why he struggles to deal with male sensitivity.

What is interesting about this episode is that it problematizes the matter of gender stereotype by explicitly showing a man doing a stereotypical "woman's job" and at no time it condoles with Ross's agony and discomfort in hiring the male nanny. On the contrary, most laughs in this episode come from how nonsensical Ross's behavior is and how absurd the thought of having gender biased jobs can be. An interesting way they make this point is by having Ross try and complete his thought about what he perceives to be an absurd gender role inversion, expressed more than once in his difficulty finishing his utterance: "It's weird [having a male nanny]. It's like a woman wanting to be a... a... a..." All the time he raises this question, the women give him a hard time and the only time someone actually finishes the sentence for him it is Joey who goes: "It's like a woman wanting to be a...a penis model." which comes to show the absurdity of his sexist proposition.

The second plot comes from the last episodes in the series, episodes 15, 17/18, in season 10, which deal with Rachel's life dilemma: living abroad, in Paris, "fashion capital of the world" and moving forward in her career or giving it all up to stay with Ross, the man with whom she has a daughter and so much history and who she finds out she is still in love with. In the story, Rachel has just lost her job but she gets offered a job in Paris, which she promptly accepts. Ross, feeling he will miss the love of his life, starts trying to win Rachel her job back, without telling her he is doing so. She ends up deciding to go anyways and as a last 
attempt to make her stay Ross goes to the airport to declare his love for her. She then decides to leave her job and stay in the U.S.A. with him.

There are three key points in this storyline which make it relevant as reinforcing the naturalization of stereotypical gender biased behavior. The first one is the fact that Ross goes beyond the limits of reasonable to make Rachel stay, ignoring what she wants for herself. Under the guise of "love", he manipulates her former boss in order to offer her a better salary and make extraordinary offers for her to get back to working in a job which she herself was not happy about. Later in the episode when they talk, he finally realizes she never wanted to stay and gives her the support she had been wishing for. That is where the second issue arises, as only after Ross voices his approval and understanding does Rachel manage to fully own up her dream and follow through with her decision to go to Paris.

The third key moment happens when Ross cannot contain himself and respect Rachel's decision. With the support of the group, who insists and incentivizes his visit to the airport to try and stop Rachel from fulfilling her dream, he declares his love for her when she is about to board the plane. What strikes me as sexist here is that not only did Rachel's friends and Ross himself ignore her feelings and wishes, being clearly gender biased towards Ross, but there was also never a shred of possibility that Ross would drop everything behind and go with her to Paris. We know from previous episodes that he had just got tenure at his university job but that should not have kept him from supporting Rachel or compromising so she could also feel accomplished. As stereotypically expected, the woman drops her career to stay with her man and her family.

The details of the scenes have been described in Table 6 so as to work as guidance when putting together the video clip with the plots described before.

Table 6

\begin{tabular}{|l|l|l|l|}
\hline \multicolumn{2}{|l|}{ Scenes - Script } \\
\hline SCENE \#1 - Ross's nonsensical prejudice against the male nanny. TOTAL: +/- 12min. \\
\hline s09e06 & Start at: & Cut at: & PLOT \\
\hline & $3^{\prime} 55^{\prime \prime}$ & $5^{\prime} 18^{\prime \prime}$ & $\begin{array}{l}\text { Ross and Rachel interview a few prospect nannies but show no sign of } \\
\text { finding one. Sandy shows up with a great CV. }\end{array}$ \\
\hline & $10^{\prime} 11^{\prime \prime}$ & $12^{\prime} 58^{\prime \prime}$ & $\begin{array}{l}\text { Ross and Rachel interview Sandy and he seems to be the perfect nanny. } \\
\text { Rachel insists they give him a try despite Ross's discomfort with the fact } \\
\text { he is a guy. }\end{array}$ \\
\hline
\end{tabular}

(continue on the next page) 
(Table 6-continuation)

\begin{tabular}{|c|c|c|c|}
\hline & $166^{\prime} 03$ & $18^{\prime} 14^{\prime \prime}$ & $\begin{array}{l}\text { Ross arrives home and Rachel is crying on the couch with Sandy. Ross } \\
\text { argues the case Sandy is "too sensitive", which does not convince } \\
\text { Rachel. }\end{array}$ \\
\hline & $19^{\prime} 10^{\prime \prime}$ & $19 ' 58 "$ & $\begin{array}{l}\text { Ross talks to Monica and Joey about Sandy. Monica does not condole } \\
\text { with Ross. Joey ridiculously helps Ross finish the sentence: "It's weird } \\
\text { [a guy being a nanny]. It's like a woman wanting to be a...penis model." }\end{array}$ \\
\hline & $248^{\prime \prime}$ & $27^{\prime} 05^{\prime \prime}$ & $\begin{array}{l}\text { Ross talks to Rachel about how unconformable he feels and she grants } \\
\text { him permission to fire Sandy, despite her disagreement. }\end{array}$ \\
\hline & $27 ' 59 "$ & $31 ' 25 "$ & $\begin{array}{l}\text { Ross fires Sandy who takes it very well because he has many offers in } \\
\text { line, being the good professional he is. He decides to get feedback from } \\
\text { Ross as to why he is being fired and instead he gets Ross to crack down } \\
\text { and open up to him about his fatherly issues, proving his prejudice } \\
\text { makes no sense as it is a result of his own personal issues. }\end{array}$ \\
\hline \multicolumn{4}{|c|}{ SCENE \#2 - Ross and Rachel's stereotypical happy ending. TOTAL: +/- 13min. } \\
\hline \multirow[t]{6}{*}{ s10e15 } & Start at: & Cut at: & PLOT \\
\hline & 2'04" & 2'27" & Ross finds out Rachel is leaving for Paris to pursue her career. \\
\hline & 4'44" & 7'05" & $\begin{array}{l}\text { Ross takes matters into his own hands and goes to Ralph Lauren to get } \\
\text { Rachel her job back. }\end{array}$ \\
\hline & $87^{\prime \prime}$ & 9'53" & $\begin{array}{l}\text { Rachel tells Ross she got an offer from Ralph Lauren and an even bigger } \\
\text { offer from Louis Vuitton, which means she is still going to Paris. }\end{array}$ \\
\hline & $14 ' 21 "$ & $15^{\prime} 40^{\prime \prime}$ & Ross goes back to Ralph Lauren. \\
\hline & $19^{\prime} 38^{\prime \prime}$ & 22 '24" & $\begin{array}{l}\text { Rachel tells Ross she will accept the offer this time but he senses she is } \\
\text { sad. He convinces her to take the job in Paris and forget about Ralph } \\
\text { Lauren. }\end{array}$ \\
\hline \multirow[t]{4}{*}{ s10e17e18 } & 0'47" & 1 1'20" & Rachel wakes up next to Ross after having slept together. \\
\hline & 644 & 7'24" & $\begin{array}{l}\text { Ross and Rachel see each other the morning after. Rachel is still going } \\
\text { to Paris. She saw the night before as "the perfect way to say goodbye". }\end{array}$ \\
\hline & $37^{\prime} 05^{\prime \prime}$ & $38 ' 53^{\prime \prime}$ & At the airport, Ross asks Rachel to stay as he declares his love for her. \\
\hline & $400^{\prime} 04$ & $43^{\prime}$ & $\begin{array}{l}\text { Ross gets home disappointed Rachel has left. Rachel shows up at Ross's } \\
\text { house as she got off the plane after realizing she is in love with him. } \\
\text { They shall live happily ever after. }\end{array}$ \\
\hline
\end{tabular}

\subsection{THE SEMANTICS DIFFERENTIALS SCALE (SDS)}

A semantic differential scale is a scaling tool used to measure social attitudes, especially in the fields of linguistics and social psychology. When using this tool, the subject is forced to focus on specific aspects and "dimensions" since categories are actually provided by the researcher, as stated by Jayme Al-Hindawe (1996). This can prove rather appropriate in 
the search for specific effect once the researcher has full control of the kind of answers they will receive according to Al-Hindawe (1996).

Basically there are two essential components to building a semantic differentials scale, as AL-Hindawe (1996) states. The first one is in regard to the choice of adjectives. The second one is about the layout of the scale itself. For this research, the SDS had also to indicate the subjects' gender, age and level in order to provide the information needed when crossing data in the analysis, as seen in Table 7.

Table 7

\begin{tabular}{|c|c|c|c|c|c|c|}
\hline GROUP XX & MALE $\square$ & FEMALE $\square$ & AGE: & \multicolumn{3}{|c|}{ LEVEL: } \\
\hline \multicolumn{7}{|c|}{ SCENE XX - XXXXXXXXXXXXXXXXXX } \\
\hline$\leftarrow$ & & & + & & & $\rightarrow$ \\
\hline ADJECTIVE & really & kind of & NEUTRAL & kind of & really & ADJECTIVE \\
\hline funny & $\square$ & $\square$ & $\square$ & $\square$ & $\square$ & not funny \\
\hline usual & $\square$ & $\square$ & $\square$ & $\square$ & $\square$ & unusual \\
\hline boring & $\square$ & $\square$ & $\square$ & $\square$ & $\square$ & entertaining \\
\hline Uninteresting & $\square$ & $\square$ & $\square$ & $\square$ & $\square$ & interesting \\
\hline Appropriate & $\square$ & $\square$ & $\square$ & $\square$ & $\square$ & inappropriate \\
\hline Offensive & $\square$ & $\square$ & $\square$ & $\square$ & $\square$ & not offensive \\
\hline predictable & $\square$ & $\square$ & $\square$ & $\square$ & $\square$ & surprising \\
\hline annoying & $\square$ & $\square$ & $\square$ & $\square$ & $\square$ & pleasant \\
\hline uncomfortable & $\square$ & $\square$ & $\square$ & $\square$ & $\square$ & $\mathrm{OK}$ \\
\hline
\end{tabular}

The adjectives chosen to compose the SDS had to identify aspects of humor and gender bias awareness within students' opinions. Taking into consideration how important it would be to determine how antonyms work in such a scale. According to Al-Hindawe (1996) this is crucial in the success of the survey as many times one word may have different connotations and these will only be perceived accordingly depending on the play on antonyms, which can be complementary opposites or gradable (Al-HINDAWE, 1996). The researcher should carefully decide for which to use each time so as to extract the most from the subjects' opinion.

Another point of concern is to avoid ambiguity and focus on relevance so that the survey itself carries the significance the researcher wants it have. It is very interesting to devise the scale based on a pilot scale but it can also be defined "a priori", as Al-Hindawe (1996) indicates. In this case, it is important to make sure the adjectives truly represent the dimensions the researcher is looking forward to approach. In this experiment, the adjectives were defined "a priori" based on the purpose of the analysis that was to take place afterwards. 
The last consideration regarding adjectives concerns the total number of adjectives, which should never be so many that subjects get bored or tired of answering nor so few that they lack the content the researcher is investigating (Al-HINDAWE 1996).

As seen in Table 7, he choice was made so as to have negative and positive adjectives randomly distributed so as not to influence students' decision or them trying to guess what the teacher wanted form them by creating a bias "good" on one side vs. "bad" on the other side. Bearing this in mind, the choice of the adjectives themselves was based on the concept of how funny students might have found the scenes and how touched they were by the sexism imprinted in the plots.

There were nine pairs of adjectives in total. Starting with the dimension of "funny", they were directly asked how funny they found the scenes by giving them the antonyms "funny vs. "not funny". The use of "not" before the adjective is a good resource when looking for an antonym because it leaves no room for doubt or dubious interpretation, as Al-Hindawe points out (reference?). Still under this umbrella of humor, there are a couple of pairs worth highlighting due to the singularity and subtlety of their meanings. The first one is the opposites "boring" vs. "entertaining" and "uninteresting" vs. "interesting". Although "boring" can be the antonym to both "entertaining" and "interesting", the aim here was to understand how tedious or fun students found watching the scenes as well as how much interest they paid to the topic, the plot and the scenes themselves.

Regarding gender bias, there was extra caution in the choice of the adjectives since they could not be so obvious as to hint to students what the research was focused on but they had to infer feelings concerning their awareness to the subject matter. Therefore, they were asked how comfortable they felt watching the scenes and how annoyed and/or offended they were by them ("uncomfortable" vs. "OK", "annoying" vs. "pleasant"). There were two pairs which were a bit more straightforward and aggressive as they meant to focus on their awareness of the stereotypes presented in the scenes, such as "offensive vs. "not offensive", "appropriate vs. inappropriate") and other which covered the same awareness in a more positive, lighter way, such as "unusual vs. usual”, "predictable vs. surprising”.

As for the layout, the listing must be carefully thought in terms of keeping them either obviously all positive dimensions on one side and all negative on the other or all mixed, so as to not bias the experiment, as Al-Hindawe points out (1996). Another point in terms of 
layout is how to choose the number of points between the adjectives. Al-Hindawe suggests something between five and nine points, preferably an odd number to ensure a neutral point. For the sake of this study, a five-point scale was devised so as to keep it more straightforward. As the objective was to keep it more obvious, the neutral point was clearly marked and the intensity of the dimensions were indicated with "kind of" and "really" (see Table 7), marked by the arrows pointing outwards from the center point of the scale. It was made in color to facilitate students' reading. Also, there were no numbers, just boxes where students ticked their preferences.

\subsection{THE EXPERIMENT}

The experiment was run with five groups, two on the same day and time and the three others separately. They all followed the same steps.

In the case of the two groups who worked together, they were first sat together in one big room where they received the instructions and sorted out doubts concerning vocabulary. The semantic differentials scale was explained in details as for the layout, the information it contained and what students were supposed to do. A copy of the scale was pasted on the eboard and every single detail was clarified. After modeling the activity students understood what they had to do and moved to separate rooms where they would watch the scenes.

In one room a group started by watching the stereotypical scene in which "Ross and Rachel stay together" and when they had finished filling out the scale the problematic scene in which "Ross and Rachel are looking for a nanny" was played to them. After they watched it, they filled out a second scale. The other group did the same, except that the order of the scenes was inverted to neutralize any possible influence. When they both had finished, the scales were collected.

It is important to highlight that no information about the experiment was given to them. They did the activity without being aware of the underlying reasons they were watching the two scenes so as to avoid bias while ticking their answers. 
After 48 hours, both groups were invited to complete the experiment by answering two more questions (Table 8), which aimed at having them say what their favorite scene was and justify why. The idea behind these questions, as mentioned previously, was to see if they could actually remember the things they were exposed to and to analyze their answers in terms of content, going deep into meaning and inference, based on feminist linguistics.

Table 8

\begin{tabular}{|r|l|}
\hline MALE ( ) FEMALE $($ ) & \multicolumn{1}{|c|}{ AGE_ LEVEL } \\
\hline You watched two scenes from FRIENDS. $\rightarrow$ & ( ) Ross and Rachel are looking for a nanny. \\
Which was your favorite? Please tick $\rightarrow$ & ( ) Ross and Rachel stay together \\
\hline Explain here why that was your favorite scene by using examples when possible \\
\hline
\end{tabular}

This was the model used with the first two groups. However, some modifications were made for the other three groups as to avoid the possibility of bias towards either one of the scenes. The instructions were somewhat confusing, especially because of the arrows used to indicate where they should tick.

Another table (see Table 9) was devised in order to resolve that.

Table 9

\begin{tabular}{|c|c|}
\hline GROUP A/B & MALE ( ) FEMALE ( ) \\
\hline You watched two scenes from F.R.I.E.N.D.S. Which was your favorite? Please tick below. \\
\hline ( ) Ross and Rachel are looking for a nanny. & ( ) Ross and Rachel stay together \\
\hline Explain here why that was your favorite scene by using examples when possible. \\
\hline \multicolumn{2}{|c|}{} \\
\hline
\end{tabular}

Depending on the group, the order of the scenes was inverted, again to avoid influencing the way students marked their answers. In fact, due to the vast majority (91\%) of students preferring the same scene this difference in layout probably did not interfere. 


\section{RESULTS AND DISCUSSION}

In this section the results will be described both in terms of quantity and quality, bearing in mind the initial objective of this research which was to understand how male and female students' perceive, if so, the underlying ideology concerning gender bias in sitcoms used in their ESL/EFL classes.

The results were pondered in regard to what male and female students found funny or funnier, especially concerning stereotypical representations of gender and/or gender roles and whether gender difference among students leads to different interpretation of this matter. The discussion revolves around how bothered or entertained students get by watching a stereotypical representation of gender as opposed to a more daring one and the direct correlation between how memorable the scenes were and how important it is for ESL/EFL teachers to carefully think about the choices they make when preparing ESL/EFL class material. As the results showed, it is paramount to raise teachers' awareness to including critical thinking in their agenda before, during and following a class and this may be the ultimate importance of this research to the field of ESL/EFL teaching, as it is a qualitative sample of how the use of media and humor in the ESL/EFL class may foster critical thinking on the matter of gender ideology and its various semiotic aspects.

As explained in the Methodology section, students were exposed to two different scenes of the sitcom F.R.I.E.N.D.S - one more stereotypical of gender and another that problematizes the stereotype - and asked to mark their opinions on a Semantic Differentials Scale (SDS) in order to understand how funny they found them and if they had noticed any gender bias. Forty-eight hours later they answered an open ended question explaining which scene they preferred so as to see how memorable the scenes had been and how much they had noticed and/or questioned/accepted the gender bias contained in them.

The results found after running the tests were particularly interesting but as exciting as this moment of the research may be, it is crucial to bear in mind certain parameters so as not to rush into conclusions without being able to support with data, as it is stated by Zyngier, Hakemulder and Van Peer (2007). 
The SDS analysis was done with the help of IBM SSPS tool, version 20, which is software that has been developed to cross data in order to create statistics. Although to a broad extent the analysis here was not quantitative and it should in no way be considered a mirror of society or even representative of all ESL/EFL students, the information drawn from it is interesting to be observed as a sample of how a group of teenage students felt when confronted with the gender issues raised by the scenes they watched.

The decision concerning how the analysis of results should take place was based on the kind of data that had been collected and taking into account the certainty that they would definitely show the relations between the independent variable in question (gender) and the other dependent variables presented in the SDS (students' opinions). In this case, the independent variable of "gender" carry a characteristic that puts it in a specific category of variables, that of "subject variable" (ZYNGIER, HAKELMULDER and VAN PEER, 2007, p.140), which means the researcher cannot manipulate and control it. This in itself may play a role in the findings and make it harder to generate causal inferences, as explained by Zyngier, Hakemulder and Van Peer (2007). That is why it is essential to take caution when drawing conclusions and in this result section the analysis will focus on stating the differences shown in the dependent variables without affirming it is so because of the subject variables, as recommended by Zyngier, Hakemulder and Van Peer (2007).

The test used in order to compare the means of answers were the Descriptive test, the ANOVA test, and the observation of Frequency graphs helped illustrate the difference between what male and female students marked on the SDS. In a nutshell, the Descriptive test was run to quantify the main features of the data collected in the survey. The ANOVA test allowed us to make an analysis of variance, which in statistical terms means to analyze how much the data varied between and within the groups of participants, raising the question as to how much influence a certain factor had on it. In the case of this survey, the factor in question was "gender", which stands for our "independent variable", or the one that remains constant and is tested for causal properties. Gender shall also be qualified as "subject variable", according to Zyngier, Hakemulder and Van Peer (2007, p.138-140), as it is not possible to manipulate or control. Against this variable, all the others, the "dependent variables" will be analyzed so as to see if gender has had any influence on them. 
The analysis of the data was done "between subjects" and "within subjects" (ZYNGIER, HAKELMULDER and VAN PEER, 2007, p.142, 145) as the information was crossed within the group of female students and within the group of male students and then between both groups. As in the second part of the research the subjects were set to do the task in a freer way, without strict parameters, it worked as a "control group" (ZYNGIER, HAKELMULDER and VAN PEER, 2007, p.148) to verify the findings of the SDS and see if any further conclusion could be drawn in terms of what students felt when they saw the scenes that had been presented to them. Again, this was not an attempt to register any causal relation between gender and what they chose, but to verify how the scenes affected them and what they understood by the adjectives presented in the SDS.

That brings the research to another point, that of "estimating validity" (ZYNGIER, HAKELMULDER and VAN PEER, 2007, p.155). The aim here is to determine the degree to which the study allows claims to be made about the relations between the variables in regard to the population itself, as highlighted by Zyngier, Hakemulder and Van Peer (2007, p.56). This validity can be "internal", meaning "the relations cannot be explained by any other variable" (ZYNGIER, HAKELMULDER and VAN PEER, 2007, p.156) besides that one previously determined and "external", when there are "reasons to believe the results can be generalized" (ZYNGIER, HAKELMULDER and VAN PEER, 2007, p.161). Under this umbrella of validity, what really mattered in this research was the concept of "construct validity" (ZYNGIER, HAKELMULDER and VAN PEER, 2007, p.164) as it is of the utmost importance to be able to "translate the concept central to our theory to measurable variables (ZYNGIER, HAKELMULDER and VAN PEER, 2007, p.164). Consequently, this is what guided the devising of the Semantics Differentials Scale (SDS).

As Table R.1 shows, students' opinions marked on the SDS were measured with focus on humor and gender bias. The idea was to see if they found the scenes funny and if they felt any kind of nuisance or discomfort with the gender role inversion and the stereotypical behavior represented in the different scenes they had watched. Two pairs of dimensions, "pleasant X annoying" and "interesting X uninteresting", were included in the SDS in an attempt to allow students to show how they perceived the whole activity of watching the scenes, regardless of what they were focusing on while watching them, as this would allow for an overall interpretation of how they liked watching them. 
Table R.1

\begin{tabular}{|c|c|c|}
\hline \multirow{2}{*}{\multicolumn{3}{|c|}{$\begin{array}{l}\text { GROUP X } \\
\text { SCENE X - XXXXXE } \square \text { XXXXXXXXXX }\end{array}$}} \\
\hline & & \\
\hline \multicolumn{3}{|c|}{$\leftarrow$} \\
\hline ADJECTIVE & NEUTRAL kind of & ADJECTIVE \\
\hline funny & Humor & not funny \\
\hline usual & Gender bias & unusual \\
\hline boring & Humor & entertaining \\
\hline uninteresting & Activity /watching the scene & interesting \\
\hline appropriate & Gender bias & inappropriate \\
\hline offensive & Gender bias & not offensive \\
\hline predictable & Gender bias & surprising \\
\hline annoying & Activity / watching the scene & pleasant \\
\hline uncomfortable & Gender bias & $\mathrm{OK}$ \\
\hline
\end{tabular}

In order to have ANOVA successfully read the results, a scale of values from 1 to 5 was associated to the degrees students were meant to mark while observing the dimensions proposed on the SDS, 1 being the most negative and 5 being the most positive combination between hedger and adjective. The decision was simply based on the meaning of the adjectives themselves, without taking into consideration the expectations and hypothesis that would have been raised by this research. In order to do so, the values associated to the scale for "funny X not funny" and "appropriate X inappropriate" had to be carefully observed because they had to be considered in a descending order as opposed to the ascending order of the scores for the other adjectives, as shown on Table R.2. It should be observed that mixing positive and negative adjectives in the columns was a mindful, deliberate decision based on the premises of how a SDS should be elaborated, as carefully explained in the Methodology section.

Table R.2

\begin{tabular}{|lllllll|}
\hline ADJECTIVE & really & kind of & NEUTRAL & kind of & really & ADJECTIVE \\
(+) funny & $\mathbf{5}$ & $\mathbf{4}$ & $\mathbf{3}$ & $\mathbf{2}$ & $\mathbf{1}$ & not funny \\
usual & 1 & 2 & 3 & 4 & 5 & Unusual $(+)$ \\
boring & 1 & 2 & 3 & 4 & 5 & Entertaining $(+)$ \\
uninteresting & 1 & 2 & 3 & 4 & 5 & Interesting $(+)$ \\
$\begin{array}{l}(+) \text { appropriate } \\
\text { offensive }\end{array}$ & $\mathbf{5}$ & $\mathbf{4}$ & $\mathbf{3}$ & $\mathbf{2}$ & $\mathbf{1}$ & Inappropriate \\
predictable & 1 & 2 & 3 & 4 & 5 & not offensive $(+)$ \\
annoying & 1 & 2 & 3 & 4 & 5 & Surprising $(+)$ \\
uncomfortable & 1 & 2 & 3 & 4 & 5 & Pleasant $(+)$ \\
\hline
\end{tabular}


As the interpretation of the results differ in terms of expectation, some assumptions were raised before running the ANOVA test (Table R.3) and then interpreted accordingly. Naturally, the hypothesis for humor was the same for both scenes and high scores, above 4, for "funny" and "entertaining" were expected to arise if they found the scenes funny and/or fun. Similarly, "pleasant" and "interesting" would receive high grades. However, regarding gender bias the expectations were obviously different because the storyline of each scene was diametrically opposite.

As explained previously, the scene that included the male nanny was meant to problematize the issue by showing how ridiculous Ross's discomfort was when confronted with the idea of having a nanny who was not typically a woman, whereas the romantic relationship between Ross and Rachel in the other scene was meant to bring forward a stereotypical view of romantic love, that according to which the woman drops her ambitions in life in order to stay with her lover/her family. Bearing this in mind, the interpretation concerning gender bias would differ in the sense that if they noticed the gender role inversion in the former scene and did not get disturbed by it, they would mark high scores for dimensions: "unusual", "appropriate", "not offensive", "surprising" and "OK". On the other hand, if they noticed the gender representation stereotype, these categories should receive low scores.

Table R.3

\begin{tabular}{|c|c|c|c|}
\hline CATEGORY & SCENE & \multicolumn{2}{|c|}{ ASSUMPTIONS / HYPOTHESIS (ideally) } \\
\hline FOCUS & MALE NANNY & HIGH / LOW & MEANING \\
\hline Humor & $\begin{array}{l}\text { funny } \\
\text { Entertaining }\end{array}$ & $\begin{array}{l}\text { high } \\
\text { high }\end{array}$ & Students found it funny / fun \\
\hline Plot as a whole & $\begin{array}{l}\text { Interesting } \\
\text { Pleasant }\end{array}$ & $\begin{array}{l}\text { high } \\
\text { high }\end{array}$ & Students enjoyed watching it \\
\hline Gender bias & $\begin{array}{l}\text { Unusual } \\
\text { Appropriate } \\
\text { Not offensive } \\
\text { Surprising } \\
\text { OK }\end{array}$ & $\begin{array}{l}\text { high } \\
\text { high } \\
\text { high } \\
\text { high } \\
\text { high }\end{array}$ & $\begin{array}{l}\text { Students noticed the gender inversion and did not } \\
\text { see any problems with it. Maybe they even noticed } \\
\text { the problem was with Ross, not Sandy. }\end{array}$ \\
\hline FOCUS & ROSS \& RACHEL & HIGH / LOW & \\
\hline Humor & $\begin{array}{l}\text { funny } \\
\text { Entertaining }\end{array}$ & $\begin{array}{l}\text { high } \\
\text { high }\end{array}$ & Students found it funny / fun \\
\hline Plot as a whole & $\begin{array}{l}\text { Interesting } \\
\text { Pleasant }\end{array}$ & $\begin{array}{l}\text { high } \\
\text { high }\end{array}$ & Students enjoyed watching it \\
\hline Gender bias & $\begin{array}{l}\text { Unusual } \\
\text { Appropriate } \\
\text { Not offensive } \\
\text { Surprising } \\
\text { OK }\end{array}$ & $\begin{array}{l}\text { low } \\
\text { low } \\
\text { low } \\
\text { low } \\
\text { low }\end{array}$ & $\begin{array}{l}\text { Students noticed the stereotype and rejected it, } \\
\text { showing some discomfort with how the story } \\
\text { unfolds. }\end{array}$ \\
\hline
\end{tabular}


The idea behind these assumptions was to guide the interpretation and clarify what was identified and analyzed in this research. In terms of humor, scoring high grades for "funny" and "entertaining" meant students probably laughed and definitely enjoyed themselves while watching the scene. By marking high scores for "pleasant" and "interesting", for example, they signaled that they did not dislike watching the scenes and maybe even liked doing so. As final consideration it is interesting to mention that the scenes were arranged with a provocative choice of plots in terms of gender bias making it essential to do the survey with "naive participants" (ZYNGIER, HAKELMULDER and VAN PEER, 2007) to avoid influencing what they marked. It goes without saying that all these assumptions would only make sense if compared and contrasted with the second part of the research in order to see if what students marked bore a correlation with what they openly said about the scene(s).

Besides that, it is of utmost importance to highlight that these are not assumptions based on expectations regarding stereotypical answers, but from the point of view of the researcher what would be considered ideal in terms of how much gender bias awareness students already have and how much fun they actually have doing such activities in the ESL/EFL classroom.

Along these lines, Table R.3 above indicates the scores hoped for while investigating the scene with the "Male Nanny" were high for: "unusual" because it would have meant they noticed the role inversion; "appropriate" and "not offensive" because then the hypothesis would be that they were not bothered by that inversion; "surprising" because of the gender role inversion but also as opposed to "predictable", maybe indicating they were surprised by the twist at the end of the episode when Sandy (the one who was discriminated against) is dismissed but in fact the one who feels awkward is Ross (the discriminator); and, finally, "OK" to show they did not feel uncomfortable with it at any moment.

Conversely, in the scene in which Ross and Rachel stay together, ideally students would have graded the same dimensions above low. Naturally, if students noticed the stereotype, they would see it as "usual", marking a low score to "unusual" and definitely "predictable" as opposed to "surprising". The same would go for the others, as it was believed they would find the plot "inappropriate", kind of "offensive", kind of "uncomfortable", if they rejected the stereotype, as table R.3 proposes. 
In the descriptive tables below produced together with the ANOVA test (table R.4) there were some interesting points that were worth highlighting. In the test results, the dependent variables were the dimensions chosen by students through the SDS and they were labeled according to each scene: "Nanny", for the one about the male nanny and "Rachel", for the one with Ross and Rachel staying together).

First, by looking at the total of students and the ratio female/male it became clear the group was divided in two equal halves thus allowing for not taking the Levine Statistics too strictly, as explained by Zyngier, Hakemulder and Van Peer (2007). In reality, the Levene's test is used to determine if the variances differ a lot or a little specially to see if the ANOVA test is recommended for the type o data that has been collected, since it is a parametric test (ZYNGIER, HAKELMULDER and VAN PEER, 2007), but statisticians claim that if groups are of an equal number the ANOVA test can still be taken as "it can take moderate violations of the assumption of homogeneity of variety" (ZYNGIER, HAKELMULDER and VAN PEER, 2007). When this is not the case, then a non-parametric test should be considered, as advised by Zyngier, Hakemulder and Van Peer (2007). In this analysis, despite the Levene statistics found for some of the variables, the ANOVA test was still used due to the observation previously mentioned.

The variation of scores (columns 5 and 6) were observed in order to check if any student or any form had been filled out incorrectly, as suggested by Zyngier, Hakemulder and Van Peer (2007). As the range marked kept the same limits and parameters as expected, the information was promptly dismissed as it plays a very small role in the analysis of the results.

Table R.4

\begin{tabular}{|c|c|c|c|c|c|c|c|}
\hline \multirow{2}{*}{\multicolumn{2}{|c|}{ DESCRIPTIVES }} & \multirow{2}{*}{$\begin{array}{l}\text { TOTAL } \\
\text { \#partic. }\end{array}$} & \multirow{2}{*}{\begin{tabular}{|l} 
Rating \\
Min. = 1 \\
Max. = \\
5
\end{tabular}} & \begin{tabular}{|l|l|}
$\begin{array}{l}\text { Level of } \\
\text { consensus }\end{array}$ \\
\end{tabular} & \multicolumn{2}{|c|}{ Scores } & Homogeneity of Variance \\
\hline & & & & $\begin{array}{l}\text { the lower, the } \\
\text { more consensus }\end{array}$ & $\begin{array}{l}\text { Rang } \\
\text { partic } \\
\text { marke }\end{array}$ & ipants & $\begin{array}{l}<0.05=\text { use non-parametric } \\
\text { tests UNLESS groups } \\
\text { have an equal \# of participants }\end{array}$ \\
\hline \multicolumn{2}{|l|}{1} & 2 & 3 & 4 & 5 & 6 & 7 \\
\hline \multicolumn{2}{|c|}{ (Dependent variables) } & $\mathrm{N}$ & Mean & Std. Deviation & Min. & Max. & Levene Statistic \\
\hline Funny Nanny & $\begin{array}{l}\text { Female } \\
\text { Male } \\
\text { Total } \\
\end{array}$ & $\begin{array}{l}20 \\
21 \\
41\end{array}$ & $\begin{array}{l}4.30 \\
4.14 \\
4.22 \\
\end{array}$ & $\begin{array}{l}.657 \\
.964 \\
.822 \\
\end{array}$ & $\begin{array}{l}3 \\
1 \\
1\end{array}$ & $\begin{array}{l}5 \\
5 \\
5 \\
\end{array}$ & .300 \\
\hline Unusual Nanny & $\begin{array}{l}\text { Female } \\
\text { Male } \\
\text { Total }\end{array}$ & $\begin{array}{l}20 \\
21 \\
41\end{array}$ & $\begin{array}{l}3.30 \\
3.05 \\
3.17\end{array}$ & $\begin{array}{l}1.455 \\
1.024 \\
1.243\end{array}$ & $\begin{array}{l}1 \\
1 \\
1\end{array}$ & $\mid \begin{array}{l}5 \\
5 \\
5\end{array}$ & 6.58 \\
\hline
\end{tabular}

(table R.4 - to be continued on the next page) 
Table R.4 (continuation)

\begin{tabular}{|c|c|c|c|c|c|c|c|}
\hline $\begin{array}{l}\text { Entertaining } \\
\text { Nanny }\end{array}$ & $\begin{array}{l}\text { Female } \\
\text { Male } \\
\text { Total } \\
\end{array}$ & $\begin{array}{l}20 \\
21 \\
41 \\
\end{array}$ & $\begin{array}{l}4.25 \\
3.19 \\
3.71 \\
\end{array}$ & \begin{tabular}{l|}
1.118 \\
1.470 \\
1.401 \\
\end{tabular} & $\begin{array}{l}2 \\
1 \\
1\end{array}$ & $\begin{array}{l}5 \\
5 \\
5\end{array}$ & 4.4 \\
\hline Interesting Nanny & $\begin{array}{l}\text { Female } \\
\text { Male } \\
\text { Total }\end{array}$ & $\begin{array}{l}20 \\
21 \\
41\end{array}$ & $\begin{array}{l}4.05 \\
3.14 \\
3.59\end{array}$ & $\begin{array}{l}.999 \\
1.195 \\
1.183\end{array}$ & $\begin{array}{l}1 \\
1 \\
1\end{array}$ & $\begin{array}{l}5 \\
5 \\
5\end{array}$ & 4.66 \\
\hline Appropriate Nanny & $\begin{array}{l}\text { Female } \\
\text { Male } \\
\text { Total } \\
\end{array}$ & $\begin{array}{l}20 \\
21 \\
41 \\
\end{array}$ & $\begin{array}{l}4.20 \\
3.90 \\
4.05 \\
\end{array}$ & $\begin{array}{l}.894 \\
.944 \\
.921 \\
\end{array}$ & $\begin{array}{l}3 \\
2 \\
2\end{array}$ & $\begin{array}{l}5 \\
5 \\
5\end{array}$ & 013 \\
\hline \begin{tabular}{|ll} 
Not & Offensive \\
Nanny & \\
\end{tabular} & $\begin{array}{l}\text { Female } \\
\text { Male } \\
\text { Total }\end{array}$ & $\begin{array}{l}20 \\
21 \\
41 \\
\end{array}$ & $\begin{array}{l}4.30 \\
4.00 \\
4.15 \\
\end{array}$ & $\begin{array}{l}1.081 \\
1.049 \\
1.062 \\
\end{array}$ & $\begin{array}{l}2 \\
2 \\
2\end{array}$ & $\begin{array}{l}5 \\
5 \\
5\end{array}$ & .091 \\
\hline Surprising Nanny & $\begin{array}{l}\text { Female } \\
\text { Male } \\
\text { Total }\end{array}$ & $\begin{array}{l}20 \\
21 \\
41\end{array}$ & $\begin{array}{l}3.25 \\
2.95 \\
3.10\end{array}$ & $\begin{array}{l}1.410 \\
1.117 \\
1.261\end{array}$ & $\begin{array}{l}1 \\
1 \\
1\end{array}$ & $\begin{array}{l}5 \\
4 \\
5\end{array}$ & 2.485 \\
\hline Pleasant Nanny & $\begin{array}{l}\text { Female } \\
\text { Male } \\
\text { Total } \\
\end{array}$ & $\begin{array}{l}20 \\
21 \\
41 \\
\end{array}$ & $\begin{array}{l}4.05 \\
3.38 \\
3.71 \\
\end{array}$ & \begin{tabular}{|l}
.826 \\
1.203 \\
1.078 \\
\end{tabular} & $\begin{array}{l}3 \\
1 \\
1\end{array}$ & $\begin{array}{l}5 \\
5 \\
5\end{array}$ & 3.965 \\
\hline OK Nanny & $\begin{array}{l}\text { Female } \\
\text { Male } \\
\text { Total }\end{array}$ & $\begin{array}{l}20 \\
21 \\
41\end{array}$ & $\begin{array}{l}4.00 \\
4.29 \\
4.15\end{array}$ & $\begin{array}{l}1.522 \\
.902 \\
1.236 \\
\end{array}$ & $\begin{array}{l}1 \\
2 \\
1\end{array}$ & $\begin{array}{l}5 \\
5 \\
5\end{array}$ & 4.132 \\
\hline Funny Rachel & $\begin{array}{l}\text { Female } \\
\text { Male } \\
\text { Total }\end{array}$ & $\begin{array}{l}20 \\
21 \\
41 \\
\end{array}$ & $\begin{array}{l}3.95 \\
3.95 \\
3.95 \\
\end{array}$ & $\begin{array}{l}1.099 \\
1.161 \\
1.117 \\
\end{array}$ & $\begin{array}{l}2 \\
1 \\
1\end{array}$ & $\begin{array}{l}5 \\
5 \\
5\end{array}$ & .060 \\
\hline Unusual Rachel & $\begin{array}{l}\text { Female } \\
\text { Male } \\
\text { Total }\end{array}$ & $\begin{array}{l}20 \\
21 \\
41\end{array}$ & $\begin{array}{l}3.55 \\
3.43 \\
3.49\end{array}$ & $\begin{array}{l}1.146 \\
1.121 \\
1.121\end{array}$ & $\begin{array}{l}1 \\
2 \\
1\end{array}$ & $\begin{array}{l}5 \\
5 \\
5\end{array}$ & .051 \\
\hline $\begin{array}{l}\text { Entertaining } \\
\text { Rachel }\end{array}$ & $\begin{array}{l}\text { Female } \\
\text { Male } \\
\text { Total }\end{array}$ & $\begin{array}{l}20 \\
21 \\
41\end{array}$ & $\begin{array}{l}4.00 \\
3.86 \\
3.93\end{array}$ & $\begin{array}{l}1.124 \\
1.236 \\
1.170\end{array}$ & $\begin{array}{l}2 \\
1 \\
1\end{array}$ & $\begin{array}{l}5 \\
5 \\
5\end{array}$ & .451 \\
\hline Interesting Rachel & $\begin{array}{l}\text { Female } \\
\text { Male } \\
\text { Total }\end{array}$ & $\begin{array}{l}20 \\
21 \\
41\end{array}$ & $\begin{array}{l}3.95 \\
3.43 \\
3.68\end{array}$ & $\begin{array}{l}1.050 \\
1.076 \\
1.083\end{array}$ & $\begin{array}{l}2 \\
2 \\
2\end{array}$ & $\begin{array}{l}5 \\
5 \\
5\end{array}$ & .130 \\
\hline $\begin{array}{l}\text { Appropriate } \\
\text { Rachel }\end{array}$ & $\begin{array}{l}\text { Female } \\
\text { Male } \\
\text { Total }\end{array}$ & $\begin{array}{l}20 \\
21 \\
41\end{array}$ & $\begin{array}{l}3.85 \\
3.43 \\
3.63 \\
\end{array}$ & $\begin{array}{l}1.137 \\
1.207 \\
1.178\end{array}$ & $\begin{array}{l}1 \\
1 \\
1\end{array}$ & $\begin{array}{l}5 \\
5 \\
5\end{array}$ & .000 \\
\hline 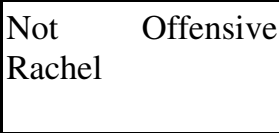 & $\begin{array}{l}\text { Female } \\
\text { Male } \\
\text { Total }\end{array}$ & $\begin{array}{l}20 \\
21 \\
41\end{array}$ & $\begin{array}{l}4.10 \\
3.95 \\
4.02\end{array}$ & $\begin{array}{l}1.334 \\
1.117 \\
1.214\end{array}$ & $\begin{array}{l}1 \\
2 \\
1\end{array}$ & $\begin{array}{l}5 \\
5 \\
5\end{array}$ & .151 \\
\hline Surprising Rachel & $\begin{array}{l}\text { Female } \\
\text { Male } \\
\text { Total }\end{array}$ & $\begin{array}{l}20 \\
21 \\
41\end{array}$ & \begin{tabular}{|l|}
3.35 \\
3.19 \\
3.27
\end{tabular} & $\begin{array}{l}1.268 \\
1.365 \\
1.304\end{array}$ & $\begin{array}{l}1 \\
1 \\
1\end{array}$ & $\begin{array}{l}5 \\
5 \\
5\end{array}$ & .232 \\
\hline Pleasant Rachel & $\begin{array}{l}\text { Female } \\
\text { Male } \\
\text { Total }\end{array}$ & $\begin{array}{l}20 \\
21 \\
41\end{array}$ & $\begin{array}{l}3.95 \\
3.43 \\
3.68\end{array}$ & $\begin{array}{l}1.234 \\
1.028 \\
1.150\end{array}$ & $\begin{array}{l}1 \\
1 \\
1\end{array}$ & $\begin{array}{l}5 \\
5 \\
5\end{array}$ & .546 \\
\hline OK Rachel & $\begin{array}{l}\text { Female } \\
\text { Male } \\
\text { Total }\end{array}$ & $\begin{array}{l}20 \\
21 \\
41\end{array}$ & $\begin{array}{l}4.60 \\
4.05 \\
4.32\end{array}$ & \begin{tabular}{|l|}
.995 \\
1.117 \\
1.083
\end{tabular} & $\begin{array}{l}1 \\
2 \\
1\end{array}$ & $\begin{array}{l}5 \\
5 \\
5\end{array}$ & 1.558 \\
\hline
\end{tabular}


By looking at the Mean in the Descriptives table R.4 above, it is easy to identify the dimensions which they ranked higher in the Semantic Differential Scale (SDS) and by carefully observing the Standard Deviation (SD), which measures the level of consensus among participants, as explained by Zyngier, Hakemulder and Van Peer (2007), it was easy to detect the points in which students had difficulty finding a consensus, either among the whole group (between groups) or among each group separately (within groups - boys amongst themselves and girls among themselves).

Still, according to the authors, the smaller the SD, the higher the consensus among the participants. Therefore, any time the SD is high it is interesting to further the investigation to try and identify how students disagree in relation to that item. Take for instance the item "Entertaining Nanny" highlighted in the table R.4 above. This is a measure of how much fun students as a whole (Total) and separately (Female / Male) had while watching the scene about Sandy, the male nanny. By running a frequency descriptive test it becomes more evident how students differ from one another, as demonstrated in Chart 1 below.

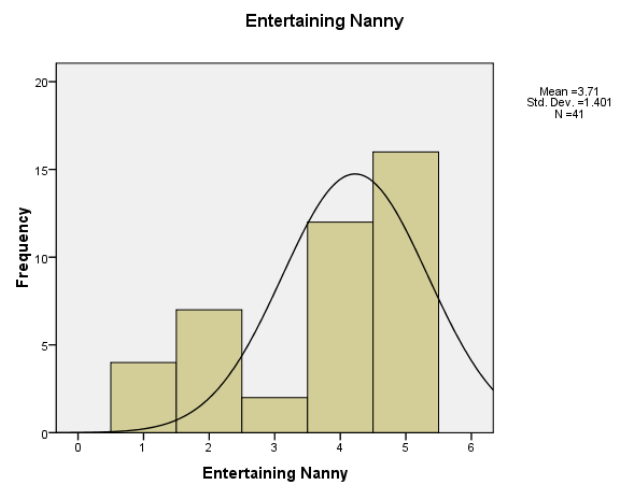

Chart 1 - Entertaining Nanny: the whole group (Total)

Even though the normal line tends to the right indicating the mean stays in the higher scores in the scale, it becomes evident that some students did not really fall in this reading of the data. For this research, It is important to understand if these students were male or female so later on when this information is crossed with the second part of the survey it adds up to a more precise data collection. Even though no conclusions will be drawn as to what caused this disagreement it is paramount to observe how this disagreement happened. In this light, another frequency descriptive test was run and Charts 2 and 3 below contain the results. 


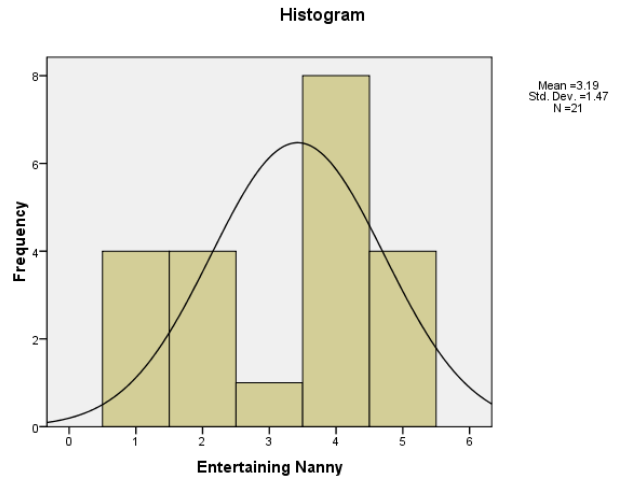

Chart 2 - Entertaining Nanny (BOYS)

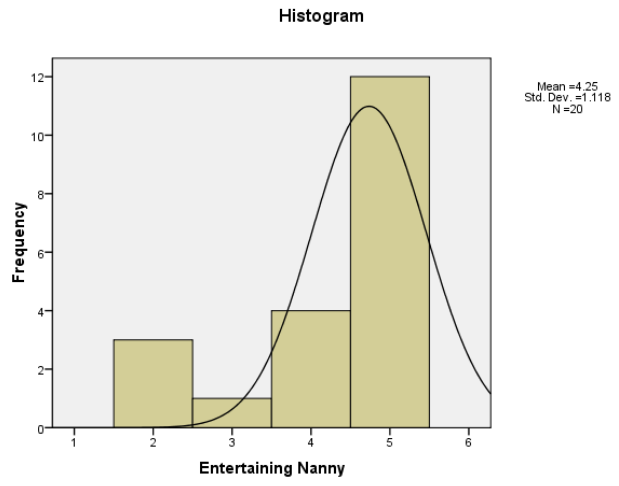

Chart 3 - Entertaining Nanny (GIRLS)

As it is illustrated here, although the mean was somewhat around the neutral point, namely 3.19 (Table R.4 above), male students disagreed a lot, much more than girls, who also differed in their responses but had most of them as a higher grade, which probably influenced the overall mean value upwards, as seen in Chart 1 before. As the dimension was evaluated from the minimum 1 (really boring) to the maximum 5 (really entertaining), according to Table R.5 below, which describes the data in Chart 2, four boys found the scene "really boring", four thought the scene was "kind of boring" and only one male student was indifferent to it, marking 1 for the neutral point in the SDS. Among the other twelve teen boys that had fun with it, 8 found it "entertaining" and 4 found it "really entertaining".

Table R.5

\begin{tabular}{|l|c|c|c|c|}
\hline \multirow{2}{*}{$\begin{array}{l}\text { Entertaining } \\
\text { Nanny) }\end{array}$} & \multicolumn{2}{|c|}{ MALE STUDENTS } & \multicolumn{2}{|c|}{ FEMALE STUDENTS } \\
\cline { 2 - 5 } & Frequency & Percent & Frequency & Percent \\
\hline REALLY boring & 4 & 19.0 & 0 & 0 \\
\cline { 1 - 1 } BORING & 4 & 19.0 & 3 & 15.0 \\
\cline { 1 - 1 } NEUTRAL & 1 & 4.8 & 1 & 5.0 \\
\cline { 1 - 1 } ENTERTAINING & 8 & 38.1 & 4 & 20.0 \\
\cline { 1 - 1 } REALLY entertaining & 4 & 19.0 & 12 & 60.0 \\
\cline { 1 - 1 } Total & 21 & 100.0 & 20 & 100 \\
\hline
\end{tabular}

As for the girls, the results were more agreeable as none of them actually found the scene "very boring" and only 3 found it boring. One girl marked 1 for neutral indicating a bit of indifference toward how much fun she had watching it and as seen on Table R.5F, the vast majority, $80 \%$ of the female students, indicated they found it either "entertaining" or "really entertaining". In this case, contrary to what happened to the male students, the mean of 4.25 showed previously in the Descriptives Table R.4 actually agrees with the Frequency data and 
could be used as a parameter to as how female students felt in relation to this dimension while watching the scene.

As a result, when the information was broken down the conclusion was that even among the boys, the majority actually had fun with the scene, even though a deceiving mean of 3.19 came out of the analysis, which might have led the research to report wrongly on this data. Boys were not indifferent to the scene as the somewhat neutral mean of 3.19 may have suggested, they indeed varied considerably in terms of how much fun they had by watching it. This is a crucial difference for later on when comparing the results found in the SDS with the second part of the survey which contains less controlled data, as it will problem raise this kind of issue as to why they preferred this or that scene.

Bearing this in mind, in order to maintain a more clear, precise interpretation of the data collected, separate tables for the two scenes were devised including the hypothetical answers expected for the dimensions in the Semantic Differentials Scale (SDS). In the first one, Table R.6 below, the data is about how students felt while watching the scene which centered on Sandy, the male nanny. As mentioned before, it's crucial to analyze this information together with the Standard Deviation (SD) so as to understand how much consensus there was among participants. As also mentioned before, for the purpose of this research some parameters in terms of expectations were created, aiming at interpreting the results in a more controlled way.

The data collected and the hypothesis raised for each item were analyzed against the mean value of the scores students marked on the SDS and the degree of consensus established by the SD. Besides that a Frequencies Descriptive test was run in order to see how frequently each dimension was rated 1 through 5 and whether that was in conformity with the mean or not. The charts illustrate the information demonstrated on the table of percentage so as to give a clearer overview of how the data behaved both within groups (Male Students X Female Students) and between them (Male Students on their own and Female Students on their own).

Still on the Frequencies Descriptive Test, it is interesting to observe that the bars show how many students actually marked that given score for that dimension and the line going across it is the normal line which represents the mean variation. The combination of tools allowed by IBM SSPS meant a deeper and more precise analysis, allowing this research to report on how some expectations were actually met while others were far from fulfilling 
themselves. Again, no causal correlation was drawn from the simple analysis of the graphs and tables showed here. On the contrary, everything reported here observes the criteria advised by Zyngier, Hakemulder and Van Peer (2007), in the sense that it describes what how the data behaved as opposed to what it did so.

Table R.6

\begin{tabular}{|c|c|c|c|c|c|c|}
\hline DESCRIPTIVES & 20 femal & e stude & nts / 21 male & students) & Consensus & Mean + SD \\
\hline (Dependent variabl & & Mean & $\begin{array}{l}\text { Hypothesis } \\
\text { (IDEALLY) }\end{array}$ & Mean Analysis & Std. Dev. & Reality \\
\hline $\begin{array}{l}\text { Funny Nanny } \\
\text { (Humor) }\end{array}$ & $\begin{array}{l}\text { Female } \\
\text { Male }\end{array}$ & $\begin{array}{l}4.30 \\
4.14\end{array}$ & high & $\begin{array}{l}\text { Ideal } \\
\text { Ideal }\end{array}$ & $\begin{array}{l}.657 \\
.964\end{array}$ & High - both (Ideal). \\
\hline $\begin{array}{l}\text { Entertaining Nanny } \\
\text { (Humor) }\end{array}$ & $\begin{array}{l}\text { Female } \\
\text { Male }\end{array}$ & $\begin{array}{l}4.25 \\
3.19\end{array}$ & high & $\begin{array}{l}\text { Ideal } \\
\text { BELOW }\end{array}$ & $\begin{array}{l}1.118 \\
1.470\end{array}$ & High - both (Ideal). \\
\hline $\begin{array}{l}\text { Pleasant Nanny } \\
\text { (Plot as a whole) }\end{array}$ & $\begin{array}{l}\text { Female } \\
\text { Male }\end{array}$ & $\begin{array}{l}4.05 \\
3.38\end{array}$ & high & $\begin{array}{l}\text { Ideal } \\
\text { BELOW }\end{array}$ & $\begin{array}{l}.826 \\
1.203\end{array}$ & $\begin{array}{l}\text { High - girls (Ideal). } \\
\text { Neutral - boys (NOT ideal) }\end{array}$ \\
\hline $\begin{array}{l}\text { Interesting Nanny } \\
\text { (Plot as a whole) }\end{array}$ & $\begin{array}{l}\text { Female } \\
\text { Male }\end{array}$ & $\begin{array}{l}4.05 \\
3.14\end{array}$ & high & $\begin{array}{l}\text { Ideal } \\
\text { BELOW }\end{array}$ & $\begin{array}{l}.999 \\
1.195\end{array}$ & High - both (Ideal). \\
\hline $\begin{array}{l}\text { Appropriate Nanny } \\
\text { (Gender Bias) }\end{array}$ & $\begin{array}{l}\text { Female } \\
\text { Male }\end{array}$ & $\begin{array}{l}4.20 \\
4.00\end{array}$ & high & $\begin{array}{l}\text { Ideal } \\
\text { Ideal }\end{array}$ & $\begin{array}{l}.894 \\
.944\end{array}$ & High - both (Ideal). \\
\hline $\begin{array}{l}\text { Not Offensive } \\
\text { Nanny } \\
\text { (Gender } \\
\text { Bias) }\end{array}$ & $\begin{array}{l}\text { Female } \\
\text { Male }\end{array}$ & $\begin{array}{l}4.30 \\
4.00\end{array}$ & high & $\begin{array}{l}\text { Ideal } \\
\text { Ideal }\end{array}$ & $\begin{array}{l}1.081 \\
1.049\end{array}$ & High - both (Ideal). \\
\hline $\begin{array}{l}\text { Unusual Nanny } \\
\text { (Gender Bias) }\end{array}$ & $\begin{array}{l}\text { Female } \\
\text { Male }\end{array}$ & $\begin{array}{l}3.30 \\
3.05\end{array}$ & high & $\begin{array}{l}\text { BELOW } \\
\text { BELOW }\end{array}$ & $\begin{array}{l}1.455 \\
1.024\end{array}$ & $\begin{array}{l}\text { High - girls (Ideal). } \\
\text { Neutral - boys. (NOT ideal) }\end{array}$ \\
\hline $\begin{array}{l}\text { Surprising Nanny } \\
\text { (Gender Bias) }\end{array}$ & $\begin{array}{l}\text { Female } \\
\text { Male }\end{array}$ & $\begin{array}{l}3.25 \\
2.95\end{array}$ & high & $\begin{array}{l}\text { BELOW } \\
\text { BELOW }\end{array}$ & $\begin{array}{l}1.410 \\
1.117\end{array}$ & $\begin{array}{l}\text { High - girls (Ideal). } \\
\text { Neutral - boys. (NOT ideal) }\end{array}$ \\
\hline $\begin{array}{l}\text { OK Nanny } \\
\text { (Gender Bias) }\end{array}$ & $\begin{array}{l}\text { Female } \\
\text { Male }\end{array}$ & $\begin{array}{l}4.00 \\
4.29\end{array}$ & high & $\begin{array}{l}\text { Ideal. } \\
\text { Ideal }\end{array}$ & $\begin{array}{l}1.522 \\
.902\end{array}$ & High - both (Ideal). \\
\hline
\end{tabular}

Under the umbrella of humor, female and male students tended to act as expected, finding the scene funny as well as fun. However, as mentioned in the example given before, the mean for boys' scores was 3.19, giving the impression they had been indifferent to this aspect of the scene. By looking at the Standard Deviation, it becomes evident there is a certain lack of consensus among them and as demonstrated before by Chart 2 and Table R.5 they actually had fun watching the scene, with only a few students, $38 \%$, finding the scene boring or very boring and 1 indifferent student. 
Before moving on to discussing how much they like the scene, it was interesting to see how funny they thought the scene was. According to Table R.6, the scene was funny for both male students and female students, with a good degree of consensus. As Charts 4 and 5 show, both boys and girls tended to find the scene either "funny" or "really funny" with very few exceptions. Among girls there was no one who did not find it funny, even though a few were indifferent to it. Among the boys, only one thought the scene was "not funny".

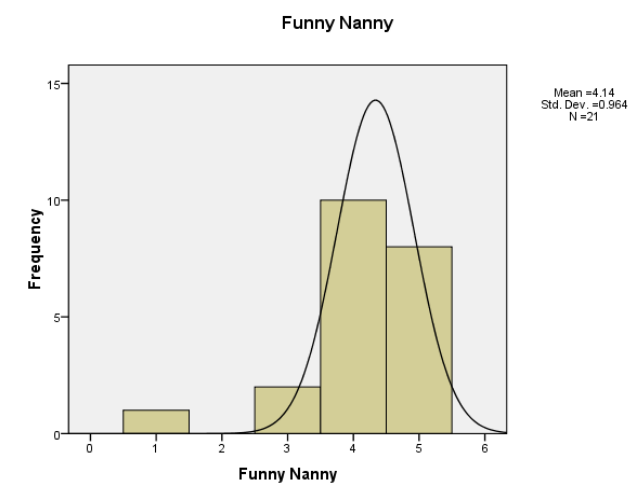

Chart 4 - Entertaining Nanny (BOYS)

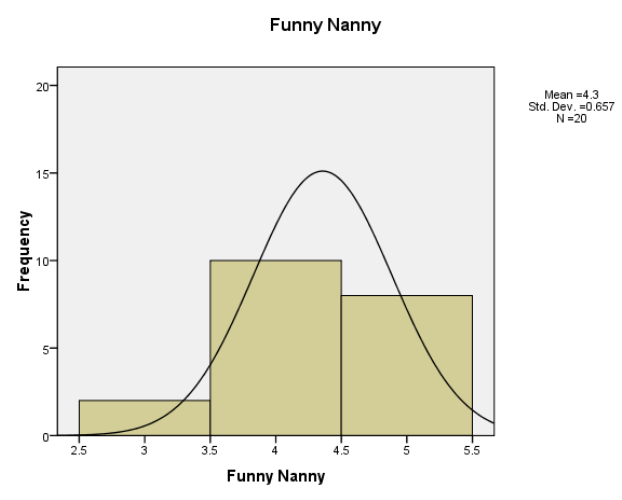

Chart 5 - Entertaining Nanny (GIRLS)

According to Table R.7 below, as many as $90 \%$ of the female students thought the scene was indeed "funny" or "really funny" while $85.7 \%$ of male students agreed. It's easy to conclude that in terms of humor this scene really fulfilled its purpose a humorous act.

Table R.7

\begin{tabular}{|l|c|c|c|c|}
\hline \multirow{2}{*}{ Funny Nanny } & \multicolumn{2}{|c|}{ MALE STUDENTS } & \multicolumn{2}{|c|}{ FEMALE STUDENTS } \\
\cline { 2 - 5 } & Frequency & Percent & Frequency & Percent \\
\hline REALLY not funny & 1 & 4.8 & 0 & 0 \\
\cline { 1 - 1 } Not funny & 0 & 0 & 0 & 0 \\
\cline { 1 - 1 } neutral & 2 & 9.5 & 2 & 10.0 \\
\cline { 1 - 1 } & 10 & 47.6 & 10 & 50.0 \\
\cline { 1 - 1 } REALLY funny & 8 & 38.1 & 8 & 40.0 \\
\cline { 1 - 1 } Total & 21 & 100.0 & 20 & 100.0 \\
\hline
\end{tabular}

As for how much they liked watching the scenes, at a first glimpse on Table R.7 above, female students followed the same pattern as before and conformed to the expectations, marking higher scores for how pleased they were and how interesting they found the scene, without much disagreement. However, once again the boys seemed to differ 
considerably in terms of consensus and their score marked "neutral", as if they had been neither annoyed nor pleased by watching the scene and had neither found it interesting nor uninteresting.

A further investigation was put forward and Charts 6 and 7 below showed that girls' opinions to as how much they enjoyed the scene and how interesting it was, in fact were much more homogeneous than those of the boys'.

Pleasant Nanny

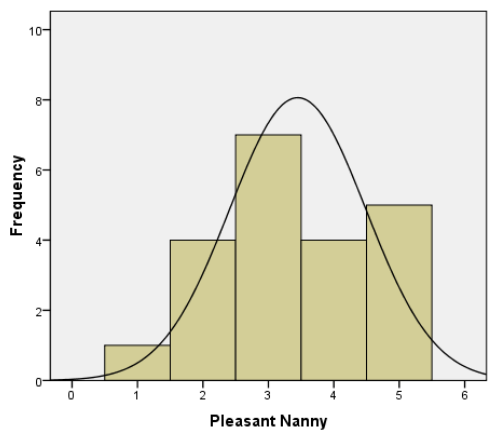

Chart 6 - Pleasant Nanny (MALE)
Pleasant Nanny
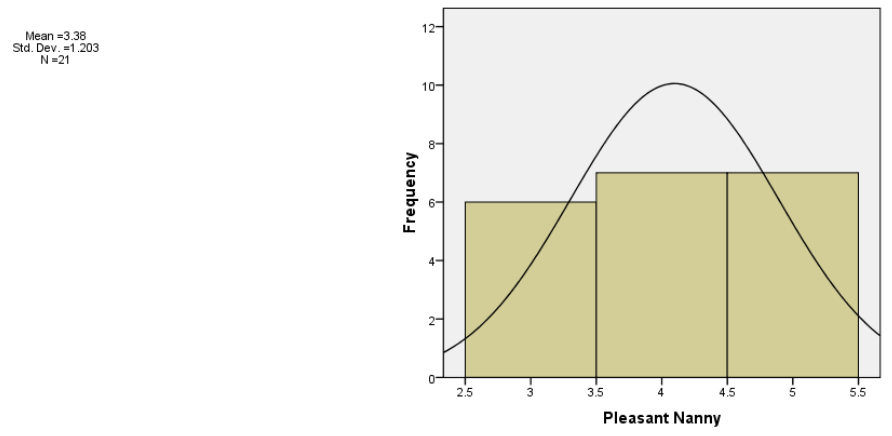

Chart 7 - Pleasant Nanny (FEMALE)

Naturally, according to Table R.8 below, this time $23.8 \%$ of male students actually rated the scene "annoying" or "really annoying" and as many as $33.3 \%$ of them were indifferent to the scene, which agrees with the interpretation given on Table R.7, leaving only $42.8 \%$ of boys who were pleased to having watched it. As for the girls, $30 \%$ were indifferent to having watched it, but as many as $70 \%$ were "pleased"/ "really pleased" they had done so.

Table R.8

\begin{tabular}{|l|c|c|c|c|}
\hline \multirow{2}{*}{ Pleasant Nanny } & \multicolumn{3}{|c|}{ MALE STUDENTS } & \multicolumn{3}{|l|}{ FEMALE STUDENTS } \\
\cline { 2 - 5 } & Frequency & Percent & Frequency & Percent \\
\hline REALLY annoying & 1 & 4.8 & 0 & 0 \\
\cline { 1 - 1 } ANNOYING & 4 & 19.0 & 0 & 0 \\
\cline { 1 - 1 } neutral & 7 & 33.3 & 6 & 30.0 \\
\cline { 1 - 1 } PLEASANT & 4 & 19.0 & 7 & 35.0 \\
\cline { 1 - 1 } REALLY pleasant & 5 & 23.8 & 7 & 35.0 \\
\cline { 1 - 1 } Total & 21 & 100.0 & 20 & 100.0 \\
\hline
\end{tabular}


As for how interesting students found the scene, they seem to have rated it quite differently again, according to Table R.7. Again, the mean for girls' opinions (4.05) is higher than the boys' (3.14) and with more consensus too. Charts 8 and 9 explore that and show female students as indeed having liked it better than male students.

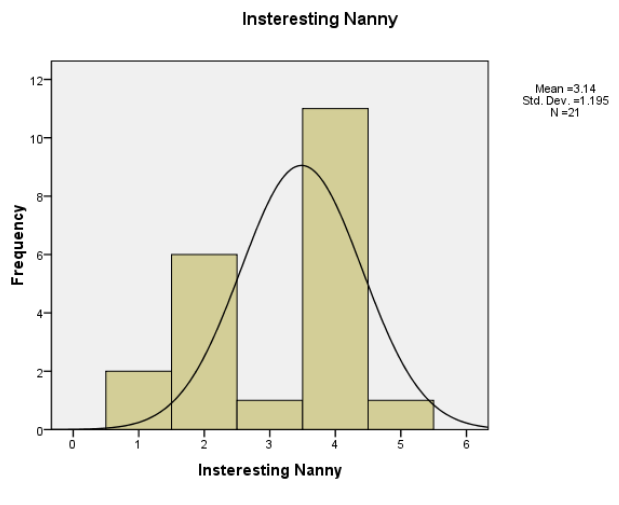

Chart 8 - Interesting Nanny (MALE)

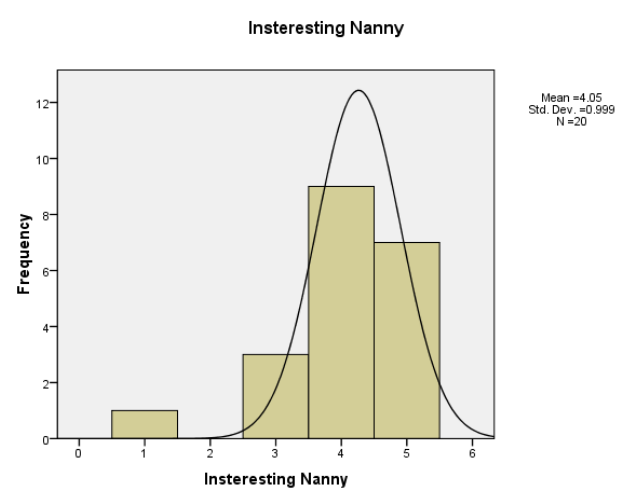

Chart 9 - Interesting Nanny (FEMALE)

Only two boys and one girl rated the scene "really uninteresting" but six boys (28.6\%) found it "uninteresting". One boy was actually indifferent to this dimension while 3 female students (15\%) felt the same. What is interesting to observe here is that while the mean value rendered male students indifferent to how interesting the scene was, $57.2 \%$ marked "interesting" or "really interesting" to it, which still makes out for the majority of them. Of course, as indicated by the tables as well as the charts, girls agreed much more and at a higher score, with $80 \%$ of the girls feeling the same (Table R.9)

Table R.9

\begin{tabular}{|l|l|l|l|l|}
\hline \multirow{2}{*}{ Interesting Nanny } & \multicolumn{3}{|l|}{ MALE STUDENTS } & FEMALE STUDENTS \\
\cline { 2 - 5 } & Frequency & Percent & Frequency & Percent \\
\hline REALLY uninteresting & 2 & 9.5 & 1 & 5.0 \\
\cline { 1 - 1 } UNINTERESTING & 6 & 28.6 & 0 & 0 \\
\cline { 1 - 1 } NEUTRAL & 1 & 4.8 & 3 & 15.0 \\
\cline { 1 - 1 } INTERESTING & 11 & 52.4 & 9 & 45.0 \\
\cline { 1 - 1 } REALLY interesting & 1 & 4.8 & 7 & 35.0 \\
\cline { 1 - 1 } Total & 21 & 100.0 & 20 & 100.0 \\
\hline
\end{tabular}


As for the adjectives chosen to represent how aware they were of the gender bias in the scene, it was remarkable to see they did not feel any discomfort with the scene and considered it both highly appropriate and not offensive, grading above four, in general, for these two dimensions, showing somewhat the same degree of consensus (Table R.7). What is curious about observing the Frequencies on Charts 10 and 11 below was the fact that even though the mean was quite high for boys and girls, they still showed indifference to this aspect to a great extent, with many of them marking the neutral point as their choice. It is also interesting to observe the charts and realize that no girl found the scene inappropriate at all, marking their grades from a minimum of 3 (neutral point) to the maximum of 5 ("really appropriate") while one boy thought the scene was "kind of inappropriate"

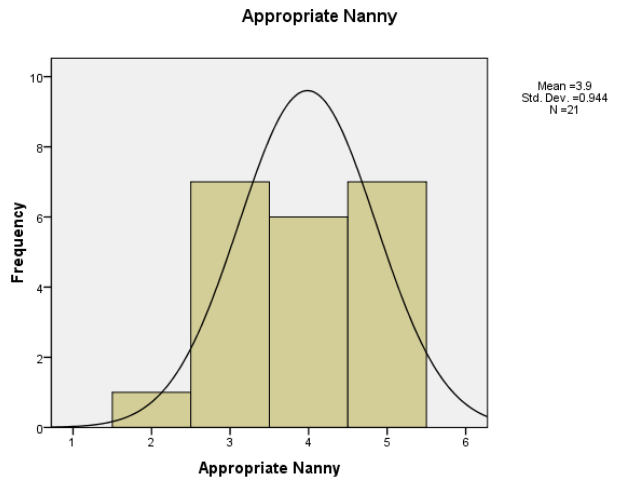

Chart 10 - Appropriate Nanny (MALE)

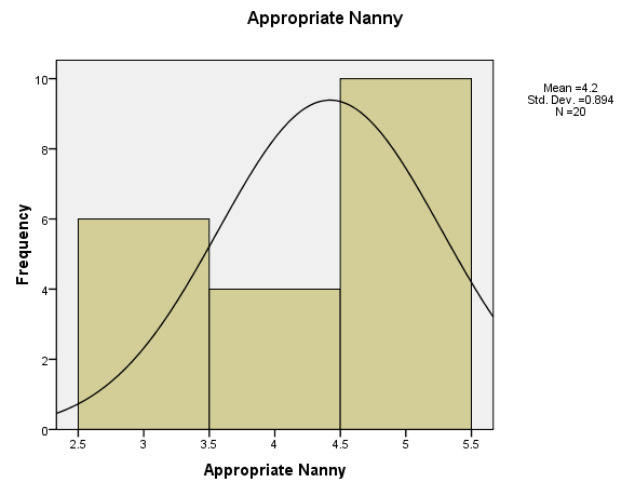

Chart 11 - Appropriate Nanny (FEMALE)

As Table R.10 confirms, as many as $70 \%$ of the girls approved of what they saw, while a not so impressive percentage of boys, $61.6 \%$, thought the same way. As expected from looking at the charts, quite a few students, around $30 \%$ of boys and girls, felt indifferent to this adjective.

Table R.10

\begin{tabular}{|l|c|c|c|c|}
\hline \multirow{2}{*}{ Appropriate Nanny } & \multicolumn{3}{|c|}{ MALE STUDENTS } & \multicolumn{2}{|l|}{ FEMALE STUDENTS } \\
\cline { 2 - 5 } & Frequency & Percent & Frequency & Percent \\
\hline REALLY inappropriate & 1 & 4.8 & 0 & 0 \\
\cline { 1 - 1 } INAPPROPRIATE & 0 & 0 & 0 & 0 \\
\cline { 1 - 1 } NEUTRAL & 7 & 33.3 & 6 & 30.0 \\
\cline { 1 - 1 } APPROPRIATE & 6 & 28.6 & 4 & 20.0 \\
\cline { 1 - 1 } REALLY appropriate & 7 & 33.3 & 10 & 50.0 \\
\cline { 1 - 1 } Total & 21 & 100.0 & 20 & 100.0 \\
\hline
\end{tabular}


As to how offensive they thought the scene was, the charts showed a little change. This time, male students seemed to agree more than the female ones. According to Table R.7, both groups behaved as expected by indicating the scene was not offensive to them. However, charts 12 and 13 below show that although most of the girls thought it was "really not offensive", there were still some girls in disagreement. As for the boys, again they showed a bigger number of individual per range of score, even though most of them actually rendered the scene "not offensive" or "really not offensive".

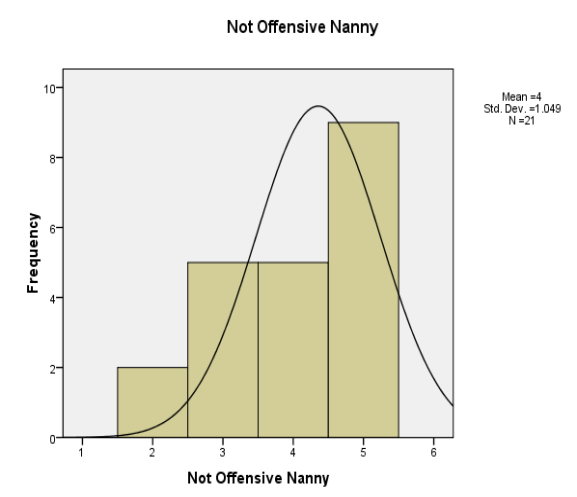

Chart 12 - Not Offensive Nanny (MALE)

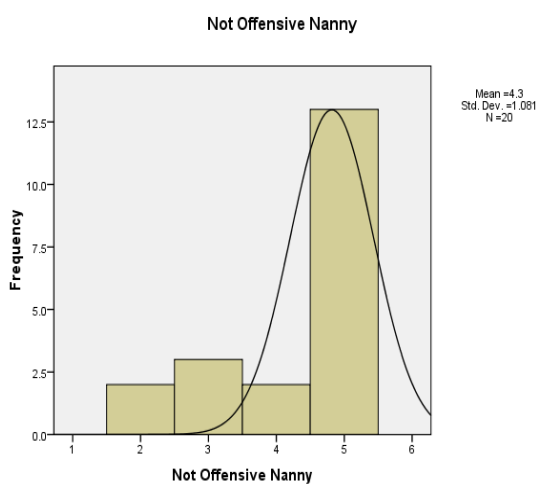

Chart 13 - Not Offensive Nanny (FEMALE)

By observing Table R.11, it is clear that $90 \%$ of both male and female students felt either indifferent, "not offended" or "really not offended" by the scene. What brings boys' mean a bit lower is the fact they were mostly indifferent to it (23.8\%), which means pretty much the same as not being offended. This result is interesting as it means both groups of male and female students were not offended by anything in the scene, including the role inversion.

Table R.11

\begin{tabular}{|c|c|c|c|c|}
\hline \multirow{2}{*}{ Not Offensive Nanny } & \multicolumn{2}{|c|}{ MALE STUDENTS } & \multicolumn{2}{|c|}{ FEMALE STUDENTS } \\
\hline & Frequency & Percent & Frequency & Percent \\
\hline REALLY offensive & 0 & 0 & 0 & 0 \\
\hline OFFENSIVE & 2 & 9.5 & 2 & 10.0 \\
\hline neutral & 5 & 23.8 & 3 & 15.0 \\
\hline NOT OFFENSIVE & 5 & 23.8 & 2 & 10.0 \\
\hline REALLY not offensive & 9 & 42.9 & 13 & 65.0 \\
\hline Total & 21 & 100.0 & 20 & 100.0 \\
\hline
\end{tabular}


As for how unusual it was to see a male nanny, it was also curious to realize that there was a certain degree of disagreement within each group, specially the female students'. If only table R.7 had been taken into consideration, the conclusion would have been that both groups were neutral regarding this dimension on the SDS. Arguably, it is also stated there that female students had a lower degree of consensus, which instigates the further investigation of these numbers. By looking at Chart 15 it is possible to conclude that different from the neutrality indicated by the mean, girls had a greater tendency to consider the scene depicting a male nanny rather uncommon while boys in fact did not really care about this aspect, as seen in Chart 14.
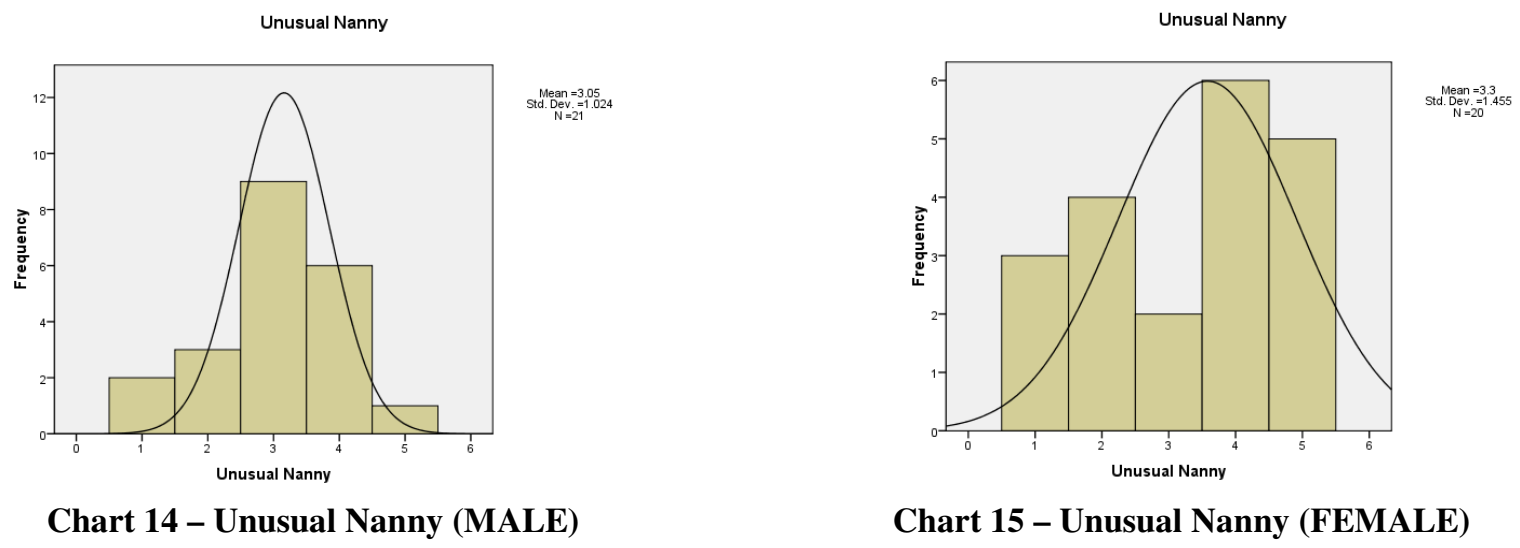

In fact, as demonstrated on Table R.12, $42.9 \%$ of the boys were oblivious to the fact a male nanny was something uncommon to see, while only $10 \%$ of the girls felt the same. Most girls (45\%) thought that was rather unusual, while $33.4 \%$ of the boys agreed with them. This came as a surprise because stereotypically male teenagers are expected to face this situation a little bit more like the girls. A point which was investigated in the second part of the survey had to do with questioning what exactly they found usual or unusual about the scene as $35 \%$ of the girls marked between "usual" and "really usual" and only $23.8 \%$ of the boys thought so too. 
Table R.12

\begin{tabular}{|l|l|l|l|l|}
\hline \multirow{2}{*}{ Unusual Nanny } & \multicolumn{3}{|l|}{ MALE STUDNTS } & \multicolumn{3}{|l|}{ FEMALE STUDENTS } \\
\cline { 4 - 5 } & Frequency & Percent & Frequency & Percent \\
\hline REALLY usual & 2 & 9.5 & 3 & 15.0 \\
\cline { 1 - 1 } & 3 & 14.3 & 4 & 20.0 \\
\cline { 1 - 1 } NEUTRAL & 9 & 42.9 & 2 & 10.0 \\
\cline { 1 - 1 } & 6 & 28.6 & 6 & 30.0 \\
\cline { 1 - 1 } REALLY unusual & 1 & 4.8 & 5 & 25.0 \\
\cline { 1 - 3 } Total & 21 & 100.0 & 20 & 100 \\
\hline
\end{tabular}

Accordingly, the dimension "surprising" followed the same pattern as the previous one, with the mean stuck at the neutral point (around 3) for both groups and again with girls seemingly disagreeing much more than the boys. When analyzing Charts 16 and 17 the disagreement among the female students becomes evident. In fact, they divided themselves pretty unequally along the grading possibilities, with most of them indeed choosing "surprising" as the dimension that defined how they felt but with many also choosing "predictable" or "really predictable". Among the boys, even though most of them agreed with the majority of the girls, they remained more negative in relation to this, considering the plot a bit more on the neutral/predictable spectrum.

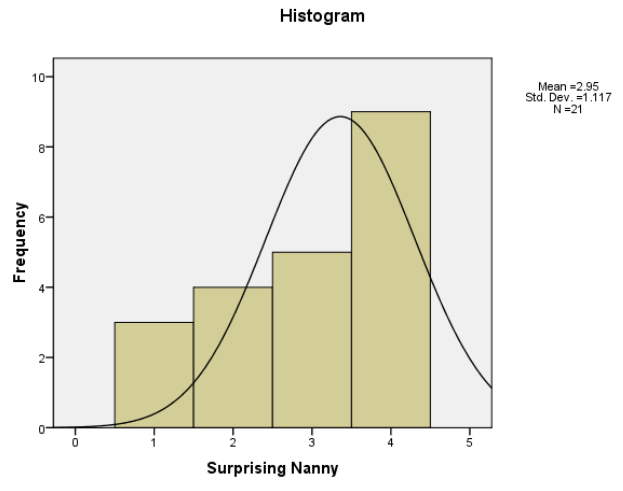

Chart 16 - Surprising Nanny (MALE)

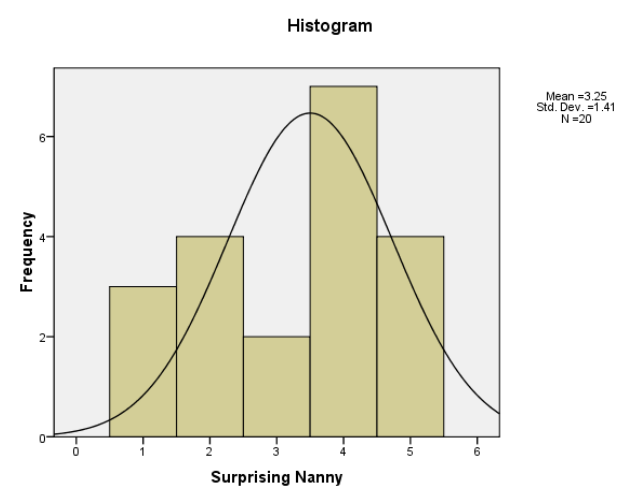

Chart 17 - Surprising Nanny (FEMALE)

This time, by looking at Table R.13, it is noticeable that $35 \%$ of male and female students were not surprised at all by what they saw. However, many male students remained indifferent to this dimension while most girls took a stand to either side of the SDS, with 55\% agreeing on how surprised they were an only $10 \%$ neutral in this respect. 
Table R.13

\begin{tabular}{|l|c|c|c|c|}
\hline \multirow{2}{*}{ Surprising Nanny } & \multicolumn{2}{|c|}{ MALE STUDENTS } & \multicolumn{2}{|c|}{ FEMALE STUDENTS } \\
\cline { 2 - 5 } & Frequency & Percent & Frequency & Percent \\
\hline REALLY predictable & 3 & 14.3 & 3 & 15.0 \\
\cline { 1 - 1 } PREDICTABLE & 4 & 19.0 & 4 & 20.0 \\
\cline { 1 - 1 } neutral & 5 & 23.8 & 2 & 10.0 \\
\cline { 1 - 1 } SURPRISING & 9 & 42.9 & 7 & 35.0 \\
\cline { 1 - 1 } REALLY surprising & 0 & 0 & 4 & 20.0 \\
\cline { 1 - 1 } Total & 21 & 100.0 & 20 & 100.0 \\
\hline
\end{tabular}

Even though the expectation towards "unusual" and "surprising" was high in the sense they would have noticed the role inversion and how unpredictably the scene unfolded (with Ross feeling uncomfortable and not Sandy), the only way to know for sure is by analyzing the second part of the survey and connecting this information gathered by the SDS with the open ended answers they did exposing a bit more what they really felt while watching the scenes. What can be drawn from this analysis so far is corroborated by how they felt about the last dimension "OK vs. uncomfortable", which seemed to reveal they really had no major issues accepting and dealing with male nanny plot, despite the variation in the female students' answers indicated on Table R.7 and confirmed by Chart 19. As for the make students, not only did they seem to have agreed more, but they also score higher for "OK" overall, as observed on Table R.7 and in Chart 18 as well.
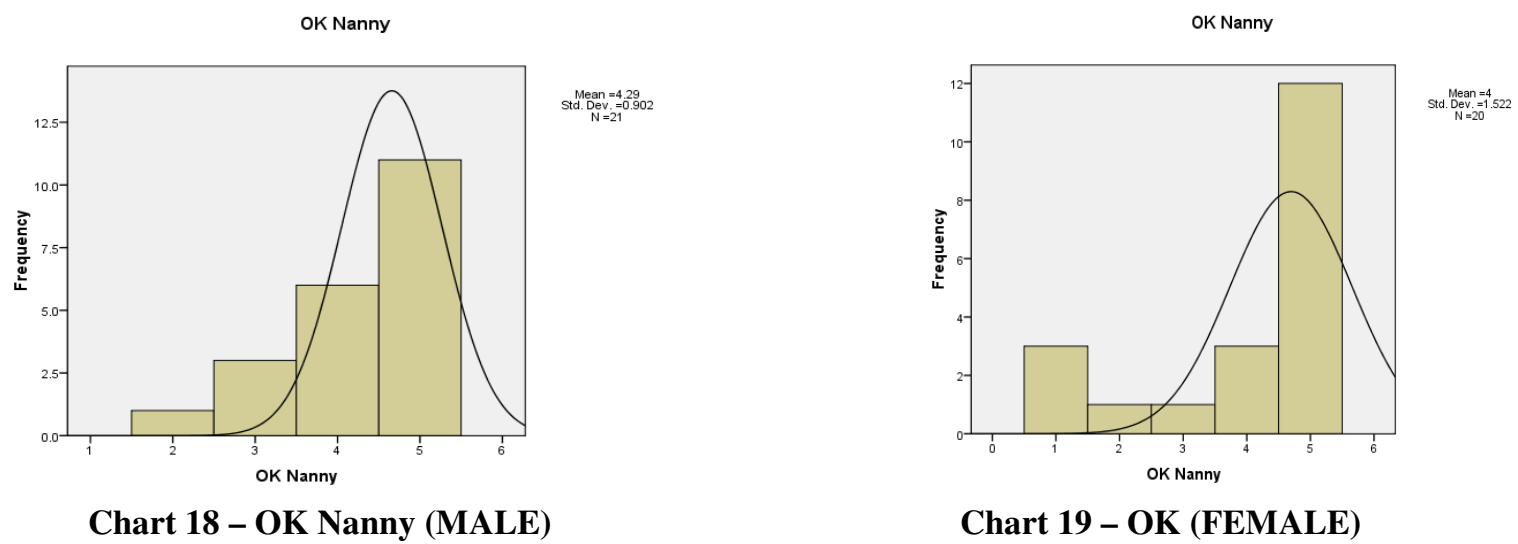

By looking at the charts above which deal with how uncomfortable students felt, the tendency follows the same pattern for both male and female students. However, from Chart 19 it is easy to conclude some girls were quite disagreeable when making their choices. Oddly 
enough, although the vast majority in both groups was OK with the scene, girls seem to have had more difficult a time coming to terms with the male nanny situation, which becomes even more evident when contrasted with the boys' choices in Chart 18 as none of them found the scene "really uncomfortable", as opposed to the three girls who thought so. This information will be addressed again when dealing with the second part of the survey.

As follows, the second set of data referring to the other scene, the one with Rachel and Ross staying together, was analyzed. Again, the Descriptives have shown how students graded the scene, how much consensus or disagreement there was among them, within their own groups and between the two of them and Table R.14 below also shows the hypothetical answers expected to be found in contrast with the reality of the answers collected, plus the results for the previous scene analyzed so another layer of comparison is added.

TABLE R.14

\begin{tabular}{|c|c|c|c|c|c|c|c|}
\hline \multicolumn{5}{|c|}{$\begin{array}{l}\text { DESCRIPTIVES (20 female students / } 21 \text { male } \\
\text { students) }\end{array}$} & \multirow{2}{*}{\begin{tabular}{|l|} 
Consensus \\
Std. Dev.
\end{tabular}} & \multirow{2}{*}{$\begin{array}{c}\text { Mean + SD } \\
\text { Reality }\end{array}$} & \multirow{2}{*}{$\begin{array}{l}\text { MALE NANNY } \\
\text { Reality }\end{array}$} \\
\hline (Dependent variable & & Mean & $\begin{array}{c}\text { Hypothesis } \\
\text { (ideally) }\end{array}$ & $\begin{array}{c}\text { Mean } \\
\text { Analysis }\end{array}$ & & & \\
\hline $\begin{array}{l}\text { Funny Rachel } \\
\text { (Humor) }\end{array}$ & $\begin{array}{l}\text { Female } \\
\text { Male }\end{array}$ & $\begin{array}{l}3.95 \\
3.95\end{array}$ & high & $\begin{array}{l}\text { BELOW } \\
\text { BELOW }\end{array}$ & $\begin{array}{l}1.099 \\
1.161\end{array}$ & High - both (Ideal). & High - both (Ideal). \\
\hline $\begin{array}{l}\text { Entertaining } \\
\text { Rachel } \\
\text { (Humor) }\end{array}$ & $\begin{array}{l}\text { Female } \\
\text { Male }\end{array}$ & $\begin{array}{l}4.00 \\
3.86\end{array}$ & high & $\begin{array}{c}\text { Ideal } \\
\text { BELOW }\end{array}$ & $\begin{array}{l}1.124 \\
1.236\end{array}$ & $\begin{array}{l}\text { High - both (Ideal). } \\
\text { (a bit lower - boys) }\end{array}$ & High - both (Ideal). \\
\hline $\begin{array}{l}\text { Pleasant Rachel } \\
\text { (Plot as a whole) }\end{array}$ & $\begin{array}{l}\text { Female } \\
\text { Male }\end{array}$ & $\begin{array}{l}3.95 \\
3.43\end{array}$ & high & $\begin{array}{l}\text { BELOW } \\
\text { BELOW }\end{array}$ & $\begin{array}{l}1.234 \\
1.028\end{array}$ & $\begin{array}{c}\text { High - girls (Ideal). } \\
\text { Neutral - boys } \\
\text { (NOT) }\end{array}$ & $\begin{array}{c}\text { High - girls (Ideal). } \\
\text { Neutral - boys (NOT). }\end{array}$ \\
\hline $\begin{array}{l}\text { Interesting Rachel } \\
\text { (Plot as a whole) }\end{array}$ & $\begin{array}{l}\text { Female } \\
\text { Male }\end{array}$ & $\begin{array}{l}3.95 \\
3.43\end{array}$ & high & $\begin{array}{l}\text { BELOW } \\
\text { BELOW }\end{array}$ & $\begin{array}{l}1.050 \\
1.076\end{array}$ & High - both (Ideal). & High - both (Ideal), \\
\hline $\begin{array}{l}\text { Appropriate } \\
\text { Rachel } \\
\text { (Gender Bias) }\end{array}$ & $\begin{array}{l}\text { Female } \\
\text { Male }\end{array}$ & $\begin{array}{l}3.85 \\
3.43\end{array}$ & low & $\begin{array}{l}\text { ABOVE } \\
\text { ABOVE }\end{array}$ & $\begin{array}{l}1.137 \\
1.207\end{array}$ & High - both (NOT) & High - both (Ideal). \\
\hline $\begin{array}{l}\text { Not Offensive } \\
\text { Rachel } \\
\text { (Gender Bias) }\end{array}$ & $\begin{array}{c}\text { Female } \\
\text { Male }\end{array}$ & $\begin{array}{l}4.10 \\
3.95\end{array}$ & low & $\begin{array}{l}\text { ABOVE } \\
\text { ABOVE }\end{array}$ & $\begin{array}{l}1.334 \\
1.117\end{array}$ & High - both (NOT) & High - both (Ideal). \\
\hline $\begin{array}{l}\text { Unusual Rachel } \\
\text { (Gender Bias) }\end{array}$ & $\begin{array}{l}\text { Female } \\
\text { Male }\end{array}$ & $\begin{array}{l}3.55 \\
3.43\end{array}$ & low & $\begin{array}{l}\text { ABOVE } \\
\text { ABOVE }\end{array}$ & $\begin{array}{l}1.146 \\
1.121\end{array}$ & $\begin{array}{l}\text { High - girls (NOT). } \\
\text { Low - boys (Ideal) }\end{array}$ & $\begin{array}{c}\text { High - girls (Ideal) } \\
\text { Neutral - boys (NOT) }\end{array}$ \\
\hline $\begin{array}{l}\text { Surprising Rachel } \\
\text { (Gender Bias) }\end{array}$ & $\begin{array}{l}\text { Female } \\
\text { Male }\end{array}$ & $\begin{array}{l}3.35 \\
3.19\end{array}$ & low & $\begin{array}{l}\text { ABOVE } \\
\text { ABOVE }\end{array}$ & $\begin{array}{l}1.266 \\
1.365\end{array}$ & $\begin{array}{c}\text { 50/50 - girls (NOT) } \\
\text { Lower - boys } \\
\text { (Ideal) }\end{array}$ & $\begin{array}{c}\text { High - girls. (Ideal) } \\
\text { Neutral - boys (NOT) }\end{array}$ \\
\hline $\begin{array}{l}\text { OK Rachel } \\
\text { (Gender Bias) }\end{array}$ & $\begin{array}{l}\text { Female } \\
\text { Male }\end{array}$ & $\begin{array}{l}4.60 \\
4.05\end{array}$ & low & $\begin{array}{l}\text { ABOVE } \\
\text { ABOVE }\end{array}$ & $\begin{array}{l}.995 \\
1.117\end{array}$ & $\begin{array}{l}\text { High - girls (NOT). } \\
\text { High - boys (NOT). }\end{array}$ & High - both (Ideal) \\
\hline
\end{tabular}


By looking at Table R.14, in terms of humor the scene in which Ross and Rachel stay together seems to have missed the mark. According to it, for both male and female students it was not really as funny as anticipated and not even as funny as the previous scene, information which shall only be confirmed after analyzing the second part of the survey, answering which scene they preferred to watch and why. As charts 20 and 21 below show, most of the male students actually thought it was "funny" or "really funny" but many felt indifferent to it, choosing the neutral point, which in this specific dimension of comic feature could be naturally interpreted as "unfunny". Among female students, "really not funny" was never mentioned but "not funny" and "neutral" were just as popular. Which leads us to conclude that, in fact, both girls and boys found the scene funny, but with much less impact than the other scene in terms of humorous traits.

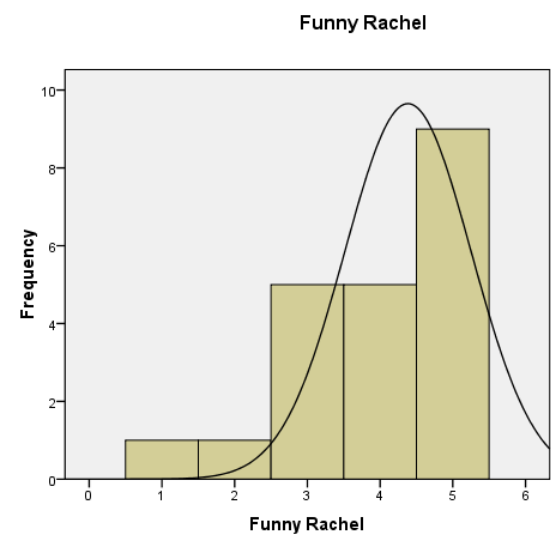

Chart 20 - Funny Rachel (MALE)

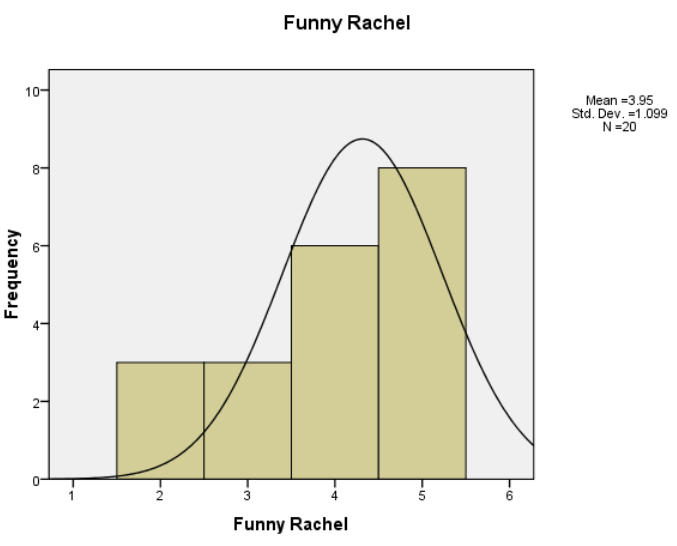

Chart 21 - Funny Rachel (FEMALE)

According to Table R.15, 33.4\% of male students classified the scene as neutral/unfunny while $30 \%$ of the girls did so too. In fact, the mean of 3.95 indicated on Table R.14 reflects this high level of indifference but does not fully explain the reality as the percentage table shows that $67 \%$ of boys and $70 \%$ of girls actually found the scene funny, with $42.9 \%$ of the male students even classifying it as "really funny". 
Table R.15

\begin{tabular}{|c|c|c|c|c|}
\hline \multirow{2}{*}{ Funny Rachel } & \multicolumn{2}{|c|}{ MALE STUDENTS } & \multicolumn{2}{|c|}{ FEMALE STUDENTS } \\
\hline & Frequency & Percent & Frequency & Percent \\
\hline REALLY not funny & 1 & 4.8 & 0 & 0 \\
\hline NOT FUNNY & 1 & 4.8 & 3 & 15.0 \\
\hline NEUTRAL & 5 & 23.8 & 3 & 15.0 \\
\hline FUNNY & 5 & 23.8 & 6 & 30.0 \\
\hline REALLY funny & 9 & 42.9 & 8 & 40.0 \\
\hline Total & 1 & 4.8 & 20 & 100 \\
\hline
\end{tabular}

Entertaining Rachel

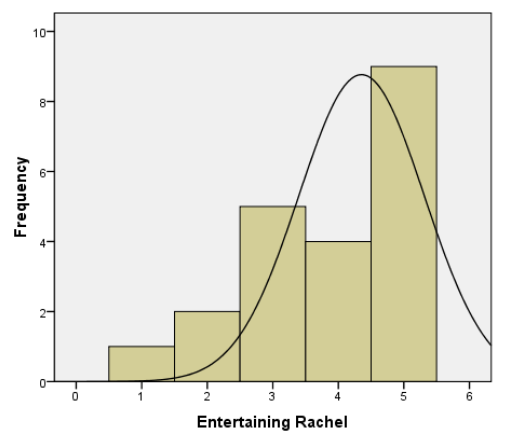

Chart 22 - Entertaining Rachel (MALE)

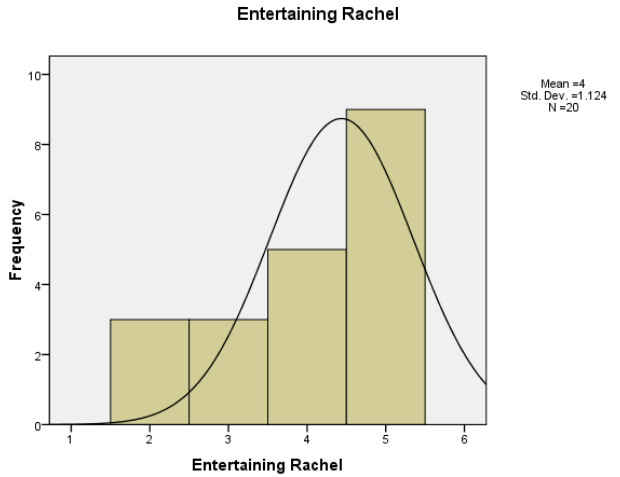

Chart 23 - Entertaining Rachel (FEMALE

As to how much fun they had watching it, girls followed the same pattern as before and concentrated their grades to the right in the scale as observed in Chart 23 above. However, boys confirmed what Table R.14 indicated and Chart 22 above shows how much they disagreed as their choice vary much more than those of the girls'. This time, looking at the percentage Table R.16 below, $61.9 \%$ of male students marked "entertaining" or "really entertaining" while again $70 \%$ of the girls indicated they were entertained or really entertained by the scene. Another interesting fact on Table R.16 is that not a single girl thought the scene to be "really boring" but one boy actually thought so which is expected to translate in the second part of the survey when they can freely express their preferences. Together, $16.3 \%$ of the boys felt negatively about this dimension "entertaining vs. boring". On the other hand, there were three girls who thought it was "boring" as opposed to the two boys, totaling $15 \%$ of negative remarks in their group, which is pretty much the same average. What seems to have made a difference here was the fact boys were not very moved by the scene, with $23.8 \%$ finding it "neutral" as far as entertainment is concerned. 
Table R.16

\begin{tabular}{|l|c|c|c|c|}
\hline \multirow{2}{*}{ Entertaining Rachel } & \multicolumn{3}{|c|}{ MALE STUDENTS } & \multicolumn{2}{|c|}{ FEMALE STUDENTS } \\
\cline { 3 - 5 } & Frequency & Percent & Frequency & Percent \\
\hline REALLY boring & 1 & 4.8 & 0 & 0 \\
\cline { 1 - 1 } BORING & 2 & 9.5 & 3 & 15.0 \\
\cline { 1 - 1 } NEUTRAL & 5 & 23.8 & 3 & 15.0 \\
\cline { 1 - 1 } ENTERTAINING & 4 & 19.0 & 5 & 25.0 \\
\cline { 1 - 1 } REALLY entertaining & 9 & 42.9 & 9 & 45.0 \\
\cline { 1 - 1 } Total & 21 & 100.0 & 20 & 100.0 \\
\hline
\end{tabular}

Regarding how pleasant to watch and interesting students found the scene, the mean values hinted again the expectations had not been met with exact the same ratings given by male students (3.43) and female students (3.95). However, the SD also on Table R.14 indicates there was a higher degree of consensus as opposed to the disagreement male students demonstrated in the previous dimensions. Even though, in fact, the difference was pretty low if compared with the degree of consensus among girls, it was still lower in relation to their own previous choices.

According to the data, boys remained indifferent as to how pleasant they found the scene, as seen un chart 21, and how much interest they paid to it, as seen in Chart 26. The big difference here is that in the former, while in the first chart the normal peaks at the neutrality point with 11 students who actually thought so and only a few others scattered along the rating scale, in the second one, "neutral" and "interesting" received the same number of indications. This shows how most male students did not exactly like watching the scene but found it interesting somehow. As for the girls, Chart 25 clearly show they found the scene "really pleasant" to watch and also thought it was "really interesting".

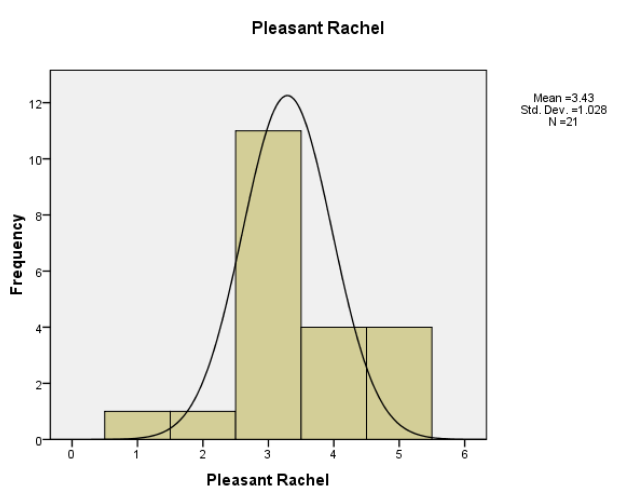

Chart 24 - Pleasant Rachel (BOYS)

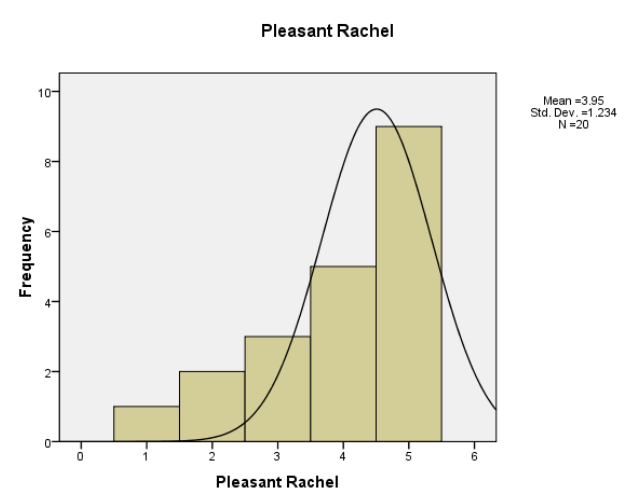

Chart 25 - Pleasant Rachel (GIRLS) 


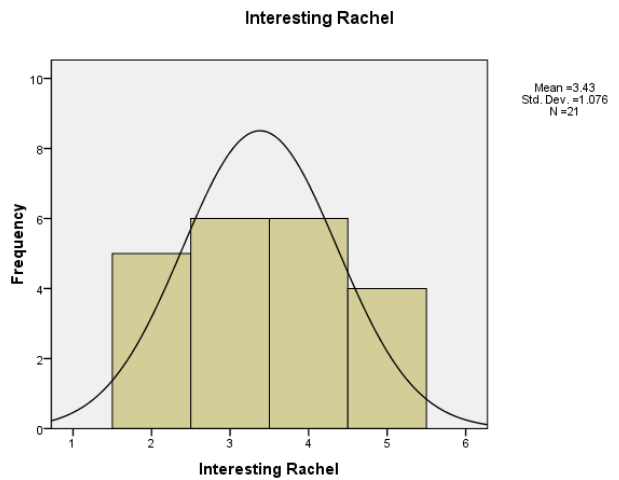

Chart 26 - Interesting Rachel (BOYS)

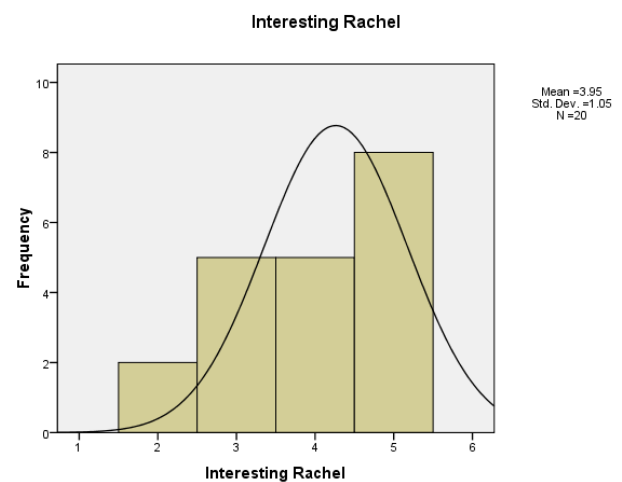

Chart 27 - Interesting Rachel (GIRLS)

As Table R.17 shows, $52.4 \%$ of the boys were neither annoyed nor pleased watching the scene as opposed to $15 \%$ of the girls only. However, $9.6 \%$ were either annoyed or really annoyed, which was interesting because it is actually low if compared with the $15 \%$ of girls who thought the same. The real difference here was that girl really enjoyed the scene much more than the boys, with $70 \%$ giving positive remarks while only $38 \%$ of the boys thought the same.

Table R.17

\begin{tabular}{|l|c|c|c|c|}
\hline \multirow{2}{*}{ Pleasant Rachel } & \multicolumn{2}{c}{ MALE STUDENTS } & \multicolumn{3}{|c|}{ FEMALE STUDENTS } \\
\cline { 2 - 5 } & Frequency & Percent & Frequency & Percent \\
\hline REALLY annoying & 1 & 4.8 & 1 & 5.0 \\
\cline { 1 - 1 } ANNOYING & 1 & 4.8 & 2 & 10.0 \\
\cline { 1 - 1 } neutral & 11 & 52.4 & 3 & 15.0 \\
\cline { 1 - 1 } PLEASANT & 4 & 19.0 & 5 & 25.0 \\
\cline { 1 - 1 } REALLY pleasant & 4 & 19.0 & 9 & 45.0 \\
\cline { 1 - 1 } Total & 21 & 100.0 & 20 & 100.0 \\
\hline
\end{tabular}

Referring back to table R.14, the analysis above meant the mean value for how much students liked the scene (3.43) was true for how pleased male students were but far from true for female students. In fact, although many boys were quite pleased (38\%) the vast majority (52.4\%) felt indifferent while the vast majority of girls (60\%) thought it was either "pleasing" or "really pleasing" to watch the scene, which did not quite reflect on their mean value (3.95). 
As for how interesting it was, Table R.18 shows that no one, either in the male group or the female group found the scene "really uninteresting" but boys did seem to pay less interest in it than the girls as $23.8 \%$ indicated by marking "uninteresting" on the SDS as opposed to the $10 \%$ of the girls who did the same. Again, indifference level was relatively high for boys as they were clearly really divided among "neutral" (28.6\%), "interesting" (28.6\%) and "really interesting" (19\%). In contrast, even though some girls were also neutral regarding how interesting the scene actually was for them, they were far more inclined to mark positive dimensions as $65 \%$ ticked "interesting" or "really interesting" on the SDS.

\section{TABLE R.18}

\begin{tabular}{|l|c|c|c|c|}
\hline \multirow{2}{*}{ Interesting Rachel } & \multicolumn{3}{|c|}{ MALE STUENTS } & FEMALE STUDENTS \\
\cline { 2 - 5 } & Frequency & Percent & Frequency & Percent \\
\cline { 1 - 1 } REALLY uninteresting & 0 & 0 & 0 & 0 \\
\cline { 1 - 1 } & 5 & 23.8 & 2 & 10.0 \\
\cline { 1 - 1 } NEUTRAL & 6 & 28.6 & 5 & 25.0 \\
\cline { 1 - 1 } INTERESTING & 6 & 28.6 & 5 & 25.0 \\
\cline { 1 - 1 } REALLY interesting & 4 & 19.0 & 8 & 40.0 \\
\cline { 1 - 1 } Total & 21 & 100.0 & 20 & 100.0 \\
\hline
\end{tabular}

In terms of how interesting both groups found the scene, again the mean value for female students, 3.95 again, also fell short for girls as $65 \%$ of them remained positive declaring they were interested in what they were watching. The boys, however, seemed to have a wider variety of responses and therefore the mean value of 3.43 ended up accounting for the bigger part of male students who marked "neutral" on the SDS (28.6\%) Still, by discarding the boys who were indifferent to this dimension, most male students tended to show some interest $(47.6 \%)$ as opposed to the uninterested ones $(23.8 \%)$. Thus, the mean value for boys was also off as it did not reflect exactly how interested boys were.

Under the umbrella of gender bias, there was the concept of "appropriate $\mathrm{x}$ inappropriate" and "offensive x not offensive", among others. The idea here was to have students mark inappropriate and offensive had they been aware of the disrespect of Ross' behavior - bribing Rachel's former boss in order to achieve his goal of holding her back in the USA with him. However, this seems to have been gone unnoticed by students in general, specially the girls, as seen in the charts and tables below and fully addressed when discussing the results of the second part of the survey. 
According to Table R.14 male and female students were indifferent to how appropriate the scene had been, with boys showing quite some disagreement about it, according to the SD. As for how offended they were by it, this time female students' mean value was higher (above 4) indicating they were not offended by it. However, the SD this time indicated less consensus among them than among the boys, whose mean value leaned slightly towards the higher end of the scale but still remained around the neutrality point,

In order to understand this information better, Chart 28 and 19 below show how not only did boys and girls differ in their perceptions of how appropriate they thought the scene was but also amongst themselves, specially boys. The vast majority of the boys remained neutral and so did many of the girls. However, it is interesting to notice that girls were mainly divided between those who did not care about this characteristic and those who completely approved of it as seen in chart 26 on the further right, and boys varied their answers a bit more.

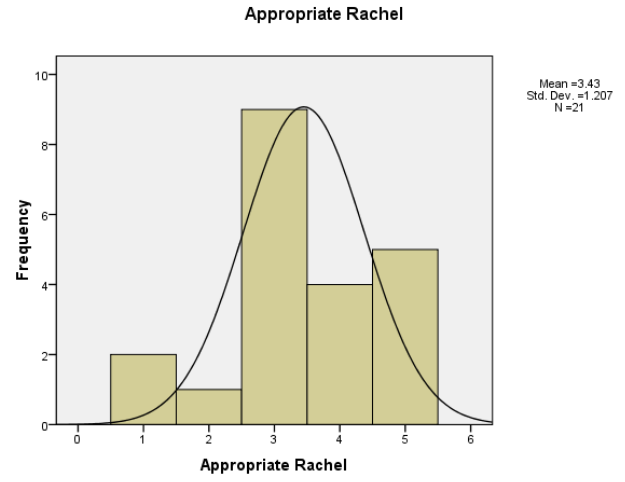

Chart 28 - Appropriate Rachel (BOYS)

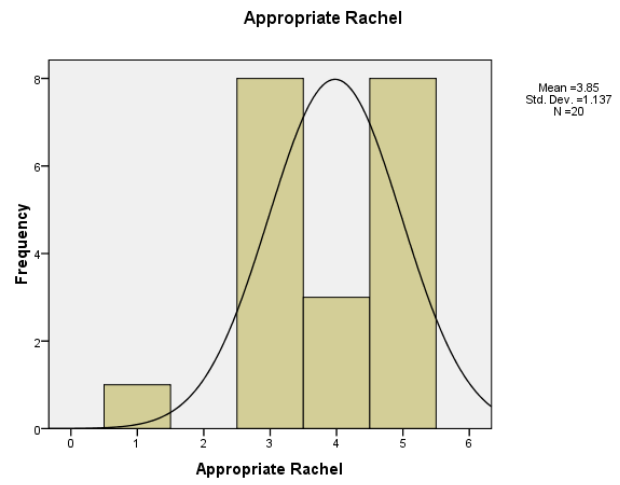

Chart 29 - Appropriate Rachel (GIRLS)

According to Table R.19 below, only $14.3 \%$ of the boys found the scene inappropriate and an even lower number of $5 \%$ of the girls (one single female student) thought the same. Most students, either male or female, were indifferent to this aspect of the scene (42.9\% of boys and $40 \%$ of girls) and among the ones left, $55 \%$ of the girls and $42.8 \%$ of the boys thought the scene to be either "appropriate" or "really appropriate". This leads to the belief that, in fact, the stereotype in itself does not disturb students. If anything, it does not make any difference and they will enjoy the scenes nonetheless. 
Table R.19

\begin{tabular}{|l|c|c|c|c|}
\hline \multirow{2}{*}{ Appropriate Rachel } & \multicolumn{5}{|c|}{ MALE STUDENTS } & FEMALE STUDENTS \\
\cline { 2 - 5 } & Frequency & Percent & Frequency & Percent \\
\hline REALLY inappropriate & 2 & 9.5 & 1 & 5.0 \\
\cline { 1 - 1 } INAPPROPRIATE & 1 & 4.8 & 0 & 0 \\
\cline { 1 - 1 } neutral & 9 & 42.9 & 8 & 40.0 \\
\cline { 1 - 1 } APPROPRIATE & 4 & 19.0 & 3 & 15.0 \\
\cline { 1 - 1 } REALLY appropriate & 5 & 23.8 & 8 & 40.0 \\
\cline { 1 - 1 } Total & 21 & 100.0 & 20 & 100.0 \\
\hline
\end{tabular}

The other dimension with the same focus as "appropriate" was "not offensive" and there seem to have been less consensus among female students this time. By observing the Charts 30 and 31 below, it is clear that the answers varied enormously, even though in the case of the girls they remained more on the higher end of the scoring system, with more girls who found the scenes either "not offensive" or "really not offensive". Boys, on the other hand, agreed among themselves in two big groups: indifferent (neutral) and "not offensive". Still, very few students, namely 2 girls only, found the scene to be "really offensive".

The mean value for both groups, although relatively accurate at around 4, hides the truth about these students who did not perceive the scene as "not offensive" or "really not offensive". This was definitely in mind when investigating the second part of the survey and will be referred back when it is time. Table R.20 also corroborates with the charts, explaining where exactly students stand in relation to this dimension. Only two boys found the scene to be offensive, accounting for $9.5 \%$ of male students. $70 \%$ of the girls were definitely not offended by anything in the scene and $57.1 \%$ of the boys felt the same. The percentage of boys who felt indifferent to the topic was $33.3 \%$ and for girls, $20 \%$, sort of following the same trend as to how appropriate the scene was. 


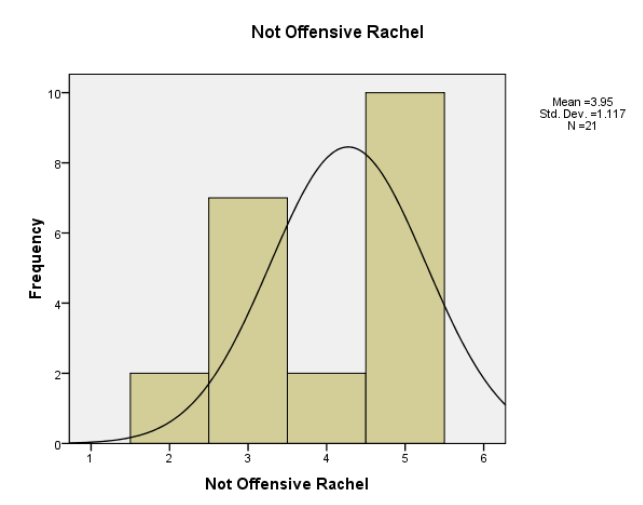

Chart 30 - Not Offensive Rachel (BOYS)

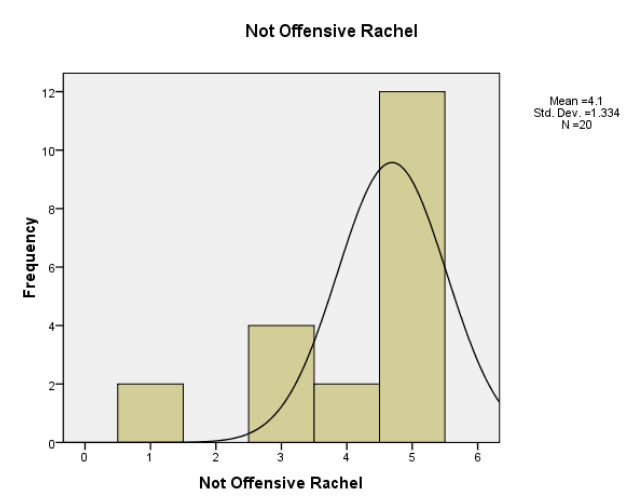

Chart 31 - Not Offensive Rachel (GIRLS)

Table R.20

\begin{tabular}{|l|c|c|c|c|}
\hline \multirow{2}{*}{ Not Offensive Rachel } & \multicolumn{3}{|c|}{ MALE STUDENTS } & \multicolumn{2}{|c|}{ FEMALE STUDENTS } \\
\cline { 2 - 5 } & Frequency & Percent & Frequency & Percent \\
\hline REALLY offensive & 0 & 0 & 2 & 10.0 \\
\cline { 1 - 1 } OFFENSIVE & 2 & 9.5 & 0 & 0 \\
\cline { 1 - 1 } neutral & 7 & 33.3 & 4 & 20.0 \\
\cline { 1 - 1 } NOT OFFENSIVE & 2 & 9.5 & 2 & 10.0 \\
\cline { 1 - 1 } REALLY not offensive & 10 & 47.6 & 12 & 60.0 \\
\cline { 1 - 1 } Total & 21 & 100.0 & 20 & 100 \\
\hline
\end{tabular}

In terms of how uncommon it is to see the situation depicted in the scene, students tended to agree that it was not exactly uncommon to see how Rachel and Ross's romantic plot unfolded, although they did not actually highlight how usual, predictable this kind of situation actually is. Charts 32 and 33 show a great difference between boys and girl in respect to how unusual they thought the scene was. To start with, male students seem to be really divided between "usual? (6 students) and "unusual" ( 7 students) while most of the girls ( 8 students) saw the scene as unusual. This was definitely not what would be ideally expected in case they were aware of how stereotypically gender biased the scene was. In fact, this should have been even more noticeable to girls since it is Rachel who was boycotted and her life that was put on hold after she decided to stay in the USA. Oddly enough it was the boys who were able to indicate how often such a thing happens (by marking "usual"). Once again, this is not a conclusion so as to why they did so and there is no attempt to draw any conclusions based on causal effects. This is just an observational fact about the data that female students overall thought the story was not as ordinary as the boys did. 


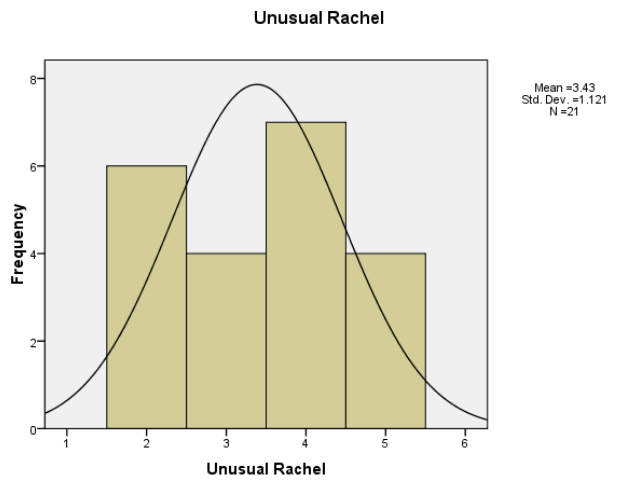

Chart 32 - Unusual Rachel (BOYS)

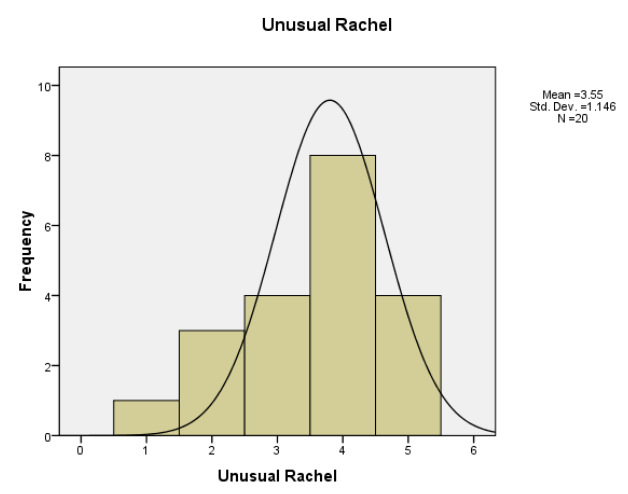

Chart 33 - Unusual Rachel (GIRLS)

As agreed on Table R.21, 19\% of male students seemed to be around the neutral point when they marked their opinions on the dimensions "unusual" and so were $20 \%$ of the girls, which may have brought the mean value down to 3.55 for girls and 3.43 for boys (Table R.14). It is clear that girls tended to find the scene a lot more unusual than the boys, who considered it mostly from indifferent to "usual" (47.6\%) against the $40 \%$ of the girls who agreed on that. $60 \%$ of the female students found the scene "unusual" or "really unusual", as opposed to $42.3 \%$ of the boys.

Table R.21

\begin{tabular}{|c|c|c|c|c|}
\hline \multirow{2}{*}{ Unusual Rachel } & \multicolumn{2}{|c|}{ MALE STUDENTS } & \multicolumn{2}{|c|}{ FEMALE STUDENTS } \\
\hline & Frequency & Percent & Frequency & Percent \\
\hline REALLY usual & 0 & 0 & 1 & 5.0 \\
\hline USUAL & 6 & 28.6 & 3 & 15.0 \\
\hline NEUTRAL & 4 & 19.0 & 4 & 20.0 \\
\hline UNUSUAL & 7 & 33.3 & 8 & 40.0 \\
\hline REALLY unusual & 4 & 19.0 & 4 & 20.0 \\
\hline Total & 21 & 100.0 & 20 & 100 \\
\hline
\end{tabular}

As for the issue of unpredictability again it was interesting to see how the SD was a bit high for both groups and how especially male students showed lower consensus towards it than girls did. As Charts 34 and 35 demonstrate, the choices varied proportionally all across the board, from "really predictable" all the way to "really surprising", with one sort of overshadowing the other. That was probably why the mean value was a bit misleading, as if they had been indifferent to this aspect of the scene, reaching 3.35 for girls and 3.19 for boys. 


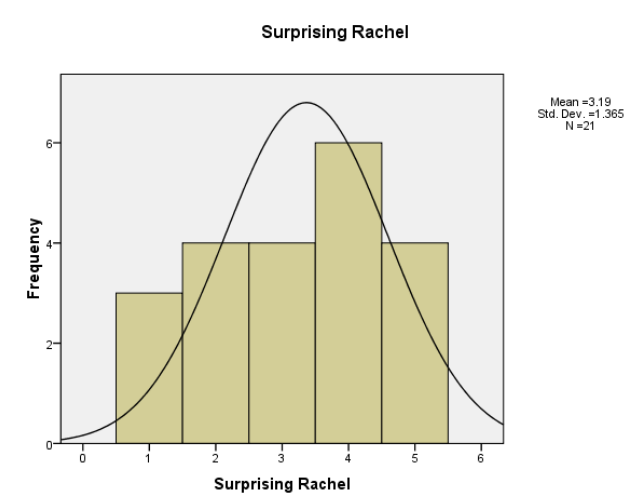

Chart 34 - Surprising Rachel (BOYS)

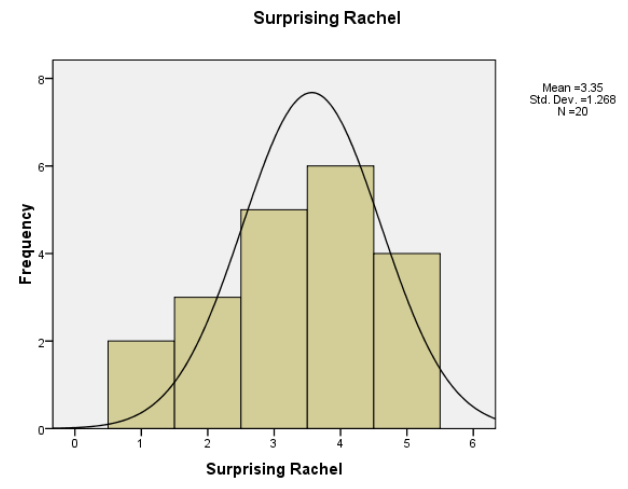

Chart 35 - Surprising Rachel (GIRLS)

It is interesting to observe Table R.22 in order to understand what really happened on the Semantic Differentials Scale regarding the unpredictability, or better still, the predictability of the plot. As many as $25 \%$ of the female students marked the SDS on the 'predictable' side whereas $50 \%$ marked the opposite, 'surprising'. As for the male students, it was considerably higher on the predictability level $(33.3 \%)$ and a little bit lower on the surprising level (47.6\%).

Table R.22

\begin{tabular}{|l|c|c|c|c|}
\hline \multirow{2}{*}{ Surprising Rachel } & \multicolumn{3}{|c|}{ MALE STUDENTS } & FEMALE STUDENTS \\
\cline { 2 - 5 } & Frequency & Percent & Frequency & Percent \\
\hline REALLY predictable & 3 & 14.3 & 2 & 10.0 \\
\cline { 1 - 1 } PREDICTABLE & 4 & 19.0 & 3 & 15.0 \\
\cline { 1 - 1 } neutral & 4 & 19.0 & 5 & 25.0 \\
\cline { 1 - 1 } SURPRISING & 6 & 28.6 & 6 & 30.0 \\
\cline { 1 - 1 } REALLY surprising & 4 & 19.0 & 4 & 20.0 \\
\cline { 1 - 1 } Total & 21 & 100.0 & 20 & 100 \\
\hline
\end{tabular}

Finally, students seem to have felt OK regarding discomfort, according to Charts 34 and 35. male students seemed to indicate a little bit more discomfort (3 students) and indifference (also 3 students) than the girls, among whom only one felt discomfort and also only one felt indifferent. On Table R.14 the SD shows that there must have been a bit less consensus among the boys and the charts corroborate that. Boys' responses varied much more than girls', as only two marked neutral or "really uncomfortable" and all the rest marked "OK" or "really OK". Among the boys there are more students who marked "uncomfortable" as well as "neutral". 


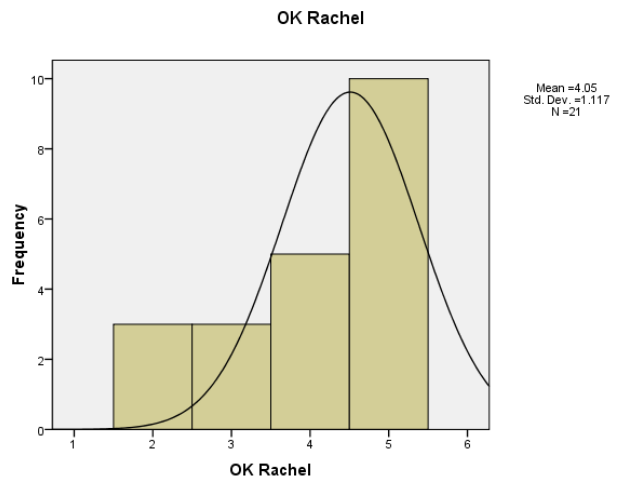

Chart 34 - OK Rachel (BOYS)

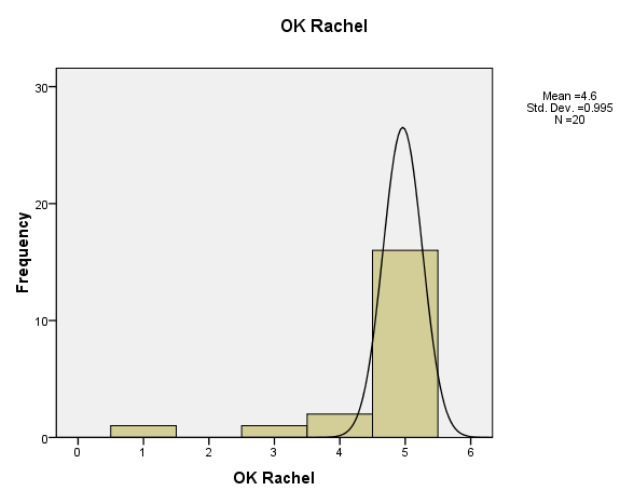

Chart 35 - OK Rachel (GIRLS)

As Table R.23 shows, $14.3 \%$ of male students felt uncomfortable which is three times the number of girls who felt the same. A few boys felt indifferent (14.3\%) and many felt OK $(23.8 \%)$ or actually "really OK" $(47.6 \%)$. However, as the table shows it does not compare to the $90 \%$ of the female students who $90 \%$ was either "OK" or "really OK" with what happened in the storyline. It seems that again it was far from the ideal expected, according to which students, specially female students, should have showed at least a bit of discomfort with Ross's boycott or Rachel having given up her dream to stay with him, as an overwhelming majority of female students saw no problem at all with the scene.

Table R.23

\begin{tabular}{|l|c|c|c|c|}
\hline \multirow{2}{*}{ OK Rachel } & \multicolumn{3}{|c|}{ MALE STUDENTS } & \multicolumn{3}{|c|}{ FEMALE STUDENTS } \\
\cline { 2 - 5 } & Frequency & Percent & Frequency & Percent \\
\hline REALLY uncomfortable & 0 & 0 & 1 & 5.0 \\
\cline { 1 - 1 } UNCOMFORTABLE & 3 & 14.3 & 0 & 0 \\
\cline { 1 - 1 } neutral & 3 & 14.3 & 1 & 5.0 \\
\cline { 1 - 1 } OK & 5 & 23.8 & 2 & 10.0 \\
REALLY OK & 10 & 47.6 & 16 & 80.0 \\
\cline { 1 - 1 } Total & 21 & 100.0 & 20 & 100 \\
\hline
\end{tabular}

As follows, the scenario after analyzing the SDS answers was more in line with what had been ideally expected for the "Male Nanny" scene, with both male and female students perceiving the scene as funny, entertaining, interesting, appropriate, not offensive and overall OK. In reality, girls kept conforming to the ideal expectations in regard to how pleasant, unusual and surprising the scene was, whereas boys did not agree on that. For them, the scene was not pleasant, unusual or surprising as much as they were indifferent to any of this dimension.

As for the other scene, the one in which with Ross and Rachel stay together, while girls found the scene funny, entertaining, pleasant and interesting, boys diverged as to how 
entertained and pleased they were. They thought the scenes were funny and interesting but a bit boring and indifferent in terms of how pleased or annoyed they were by it. In the matter of gender bias, the ideal expectations of what their answers should have indicated in case they were aware of it seems to have really fallen short as both boys and girls ignored the gender bias rendering the scene not only appropriate but also not offensive and in general OK. Furthermore, female students still thought the scene was unusual/surprising whereas male students disagreed; indicating they thought it was neither unusual nor surprising.

As a matter of fact all the data collected before can only make sense when compared to the second part of the research in which students were asked to choose the scene they had liked the most and justify their answers so as to verify if they really found the scenes funny and how much they noticed the influence of gender bias in order to create humor They were told they should use their own words and were in fact helped in terms of vocabulary so that language impairment would not be an obstacle for them to fully express their thoughts. For this stage of the research, not all the students were able to participate - only 37 out of 41 which did not compromise the analysis since the second part of the experiment was about the scenes but did not have to be matched individually to each SDS.

In this phase of the experiment there were 20 female students and 17 male, most of whom between 15 and 18, except for three boys who were 13 (2) and 14 years old. As their answers did not stray from those of the rest of the group, they were accepted with no restrictions.

In order to analyze students' data, a categorization of content was organized based on what students presented in their survey. The areas to be observed were based on the hypothesis raised by the research question introduced in this paper concerning students' sense of humor and their perception of gender bias in sitcoms and if they could be used as a tool to foster learning in the ESL/EFL classroom. After a careful scan of each questionnaire, subcategories were listed under the umbrella categories which guide this research and went as follows:

\section{7) Gender bias:}

1.1) Stereotype - supported/ignored/questioned.

1.2) Inversion of roles - marked/unmarked and relevant/irrelevant 
1.3) Male emotions - normal/ridiculed

1.4) Awareness - critical thinking/prejudice/unpredictability

\section{8) Humor}

2.1) funny/funny ha-ha/fun

\section{9) Memory}

3.1) detailed/shallow

10) When scenes were compared to one another the categorization remained the same.

4.1) funnier, read as funny/less cliché, read as the other was stereotypical/etc.

In general, the great majority of students among all ages, 32 out of 37, preferred the scene with the male nanny, regardless of which order it had been shown in relation to the scene in which Ross and Rachel stay together as a couple, no matter if they were male or female, upper-intermediate or advanced level, as highlighted on tables R.24.A and R.24.B below.

Table R.24.A

\begin{tabular}{|c|c|c|c|c|c|c|c|c|c|}
\hline \multicolumn{3}{|c|}{$\begin{array}{c}\text { MALE } \\
\text { STUDENTS }\end{array}$} & \multirow{2}{*}{\begin{tabular}{|c|} 
PREFERENCE \\
Scene
\end{tabular}} & \multirow{2}{*}{\begin{tabular}{|l} 
HUMOUR \\
funny/fun
\end{tabular}} & \multicolumn{4}{|c|}{ GENDER BIAS } & \multirow{2}{*}{$\frac{\mid \text { MEMORY }}{\text { Account }}$} \\
\hline \# & Age & Level & & & Stereotype & Role & $\begin{array}{c}\text { Male } \\
\text { Emotions }\end{array}$ & Awareness & \\
\hline 1 & 13 & Upper & Nanny(1) & irony & $\mathrm{x}$ & $\begin{array}{l}\text { Unmarked } \\
\text { Irrelevant }\end{array}$ & $\mathrm{OK}$ & $\mathrm{x}$ & Detailed \\
\hline 2 & 13 & Advanced & Nanny(2) & irony & $\mathrm{x}$ & $\begin{array}{c}\text { Marked } \\
\text { Irrelevant }\end{array}$ & $\mathrm{OK}$ & Unusual & Detailed \\
\hline 3 & 14 & Upper & Rachel(1) & $\mathrm{x}$ & ignored & $\begin{array}{l}\text { Unmarked } \\
\text { Irrelevant }\end{array}$ & $\mathrm{x}$ & Unusual & Superficial \\
\hline 4 & 14 & Upper & Nanny(2) & Funny & $\mathrm{x}$ & $\mathrm{x}$ & $\mathrm{x}$ & $\mathrm{x}$ & $\begin{array}{c}\text { Unrelated } \\
\text { D }\end{array}$ \\
\hline 5 & 15 & Upper & Nanny(1) & $\begin{array}{c}\text { Funny ha- } \\
\text { ha }\end{array}$ & $\mathrm{x}$ & $\begin{array}{c}\text { Marked } \\
\text { Irrelevant }\end{array}$ & $\mathrm{x}$ & Unusual & Superficial \\
\hline 6 & 15 & Upper & Nanny(1) & Funny & $\mathrm{x}$ & $\begin{array}{c}\text { Marked } \\
\text { Irrelevant }\end{array}$ & $\mathrm{X}$ & Critical & Detailed \\
\hline 7 & 15 & Upper & Nanny(1) & $\mathrm{x}$ & $\mathrm{x}$ & $\begin{array}{l}\text { Unmarked } \\
\text { Irrelevant }\end{array}$ & $\mathrm{OK}$ & $\mathrm{x}$ & Detailed \\
\hline 8 & 15 & Upper & Nanny(1) & Funny & $\mathrm{x}$ & $\begin{array}{l}\text { Unmarked } \\
\text { Irrelevant }\end{array}$ & $\mathrm{OK}$ & $\mathrm{x}$ & Detailed \\
\hline
\end{tabular}

(Table R.24 A - to be continued on the next page) 
Table R.24 A (continuation)

\begin{tabular}{|c|c|c|c|c|c|c|c|c|c|}
\hline \# & Age & Level & Scene & funny/fun & Stereotype & Role & $\begin{array}{c}\text { Male } \\
\text { Emotions }\end{array}$ & Awareness & Account \\
\hline 9 & 15 & Upper & Nanny(2) & Funny & $\mathrm{x}$ & $\begin{array}{l}\text { Unmarked } \\
\text { Irrelevant }\end{array}$ & $\mathrm{x}$ & $\mathrm{x}$ & Detailed \\
\hline 10 & 15 & Upper & Nanny(2) & $\begin{array}{c}\text { Funny ha- } \\
\text { ha }\end{array}$ & $\mathrm{x}$ & $\begin{array}{l}\text { Marked } \\
\text { Irrelevant }\end{array}$ & Ridiculed & $\mathrm{x}$ & Superficial \\
\hline 11 & 15 & Advanced & Nanny(2) & Funny & $\mathrm{x}$ & $\mathrm{x}$ & $\mathrm{x}$ & $\mathrm{x}$ & Detailed \\
\hline 12 & 15 & Advanced & Nanny(1) & Funny & $\mathrm{x}$ & $\begin{array}{l}\text { Marked } \\
\text { Irrelevant }\end{array}$ & $\mathrm{OK}$ & $\mathrm{x}$ & Superficial \\
\hline 13 & 16 & Upper & Nanny(1) & Funny & $\mathrm{x}$ & $\mathrm{x}$ & $\mathrm{x}$ & $\mathrm{x}$ & Superficial \\
\hline 14 & 16 & Upper & Nanny(2) & $\mathrm{x}$ & $\mathrm{x}$ & $\begin{array}{c}\text { Marked } \\
\text { Relevant }\end{array}$ & $\mathrm{OK}$ & Critical & Detailed \\
\hline 15 & 16 & Advanced & Nanny(2) & Funny & $\mathrm{x}$ & $\begin{array}{l}\text { Marked } \\
\text { Relevant }\end{array}$ & $\mathrm{OK}$ & Unusual & Detailed \\
\hline 16 & 16 & Advanced & Nanny(2) & $\mathrm{x}$ & $\mathrm{x}$ & $\begin{array}{l}\text { Unmarked } \\
\text { Irrelevant }\end{array}$ & $\mathrm{OK}$ & $\mathrm{x}$ & Superficial \\
\hline 17 & 18 & Advanced & Nanny(2) & Funny & $\mathrm{x}$ & $\mathrm{x}$ & $\mathrm{x}$ & Unusual & $\begin{array}{c}\text { Unrelated } \\
\text { D }\end{array}$ \\
\hline
\end{tabular}

Table R.24.B

\begin{tabular}{|c|c|c|c|c|c|c|c|c|c|}
\hline \multicolumn{3}{|c|}{$\begin{array}{c}\text { FEMALE } \\
\text { STUDENTS }\end{array}$} & \multirow{2}{*}{$\begin{array}{c}\text { PREFERENCE } \\
\text { Scene }\end{array}$} & \multirow{2}{*}{\begin{tabular}{|l|} 
HUMOUR \\
funny/fun \\
\end{tabular}} & \multicolumn{4}{|c|}{ GENDER BIAS } & \multirow{2}{*}{\begin{tabular}{|l|} 
MEMORY \\
Account
\end{tabular}} \\
\hline$\#$ & Age & Level & & & Stereotype & Role & $\begin{array}{c}\text { Male } \\
\text { Emotions }\end{array}$ & Awareness & \\
\hline 1 & 15 & Upper & Nanny(1) & $\begin{array}{l}\text { Funny ha- } \\
\text { ha }\end{array}$ & $\mathrm{x}$ & $\begin{array}{l}\text { Marked/ } \\
\text { Relevant }\end{array}$ & Ridiculed & Prejudist & Detailed \\
\hline 2 & 15 & Upper & Nanny(1) & Funny & $\mathrm{x}$ & $\begin{array}{l}\text { Marked/ } \\
\text { Relevant }\end{array}$ & Ridiculed & $\mathrm{x}$ & Detailed \\
\hline 3 & 15 & Upper & Rachel(2) & Funny & ignored & $\mathrm{X}$ & $\mathrm{x}$ & Unusual & Superficial \\
\hline 4 & 15 & Advanced & Nanny(1) & $\begin{array}{l}\text { Funny ha- } \\
\text { ha }\end{array}$ & $\mathrm{x}$ & $\begin{array}{l}\text { Marked/ } \\
\text { Relevant }\end{array}$ & $\mathrm{x}$ & Prejudist & Detailed \\
\hline 5 & 15 & Advanced & Nanny(1) & $\begin{array}{l}\text { Funny ha- } \\
\text { ha }\end{array}$ & $\mathrm{x}$ & $\begin{array}{l}\text { Marked/ } \\
\text { Relevant }\end{array}$ & $\mathrm{x}$ & Unusual & Superficial \\
\hline 6 & 15 & Advanced & Nanny(2) & $\begin{array}{l}\text { Funny ha- } \\
\text { ha }\end{array}$ & $\mathrm{x}$ & $\begin{array}{l}\text { Marked/ } \\
\text { Relevant }\end{array}$ & Ridiculed & Prejudist & Superficial \\
\hline 7 & 15 & Advanced & Nanny(2) & $\begin{array}{l}\text { Funny ha- } \\
\text { ha }\end{array}$ & $\mathrm{x}$ & $\begin{array}{l}\text { Marked/ } \\
\text { Relevant }\end{array}$ & Ridiculed & $\mathrm{x}$ & Detailed \\
\hline 8 & 15 & Advanced & Nanny(2) & Fun & $\mathrm{x}$ & $\begin{array}{l}\text { Unmarked/ } \\
\text { Irrelevant }\end{array}$ & $\mathrm{x}$ & $\mathrm{x}$ & Superficial \\
\hline 9 & 15 & Advanced & $\operatorname{Rachel}(2)$ & Funny & supported & $\mathrm{X}$ & $\mathrm{x}$ & $\mathrm{X}$ & Superficial \\
\hline 10 & 16 & Upper & Nanny(1) & $\mathrm{X}$ & questioned & $\begin{array}{l}\text { Unmarked/ } \\
\text { Irrelevant }\end{array}$ & $\mathrm{x}$ & $\begin{array}{l}\text { Critical } \\
\text { thinking }\end{array}$ & Detailed \\
\hline
\end{tabular}

(Table R.24 B - to be continued on the next page) 
Table R.24 B (continuation)

\begin{tabular}{|c|c|c|c|c|c|c|c|c|c|}
\hline$\#$ & Age & Level & Scene & funny/fun & Stereotype & Role & $\begin{array}{c}\text { Male } \\
\text { Emotions }\end{array}$ & Awareness & Account \\
\hline 11 & 16 & Upper & Nanny(2) & $\mathrm{x}$ & $\mathrm{x}$ & $\begin{array}{l}\text { Marked/ } \\
\text { Relevant }\end{array}$ & $\mathrm{x}$ & Unusual & Superficial \\
\hline 12 & 16 & Upper & Rachel(2) & Funny & supported & $\mathrm{X}$ & $\mathrm{x}$ & $\mathrm{x}$ & Detailed \\
\hline 13 & 16 & Advanced & Nanny (1) & Funny & supported & $\begin{array}{l}\text { Marked/ } \\
\text { Relevant }\end{array}$ & $\mathrm{x}$ & $\mathrm{x}$ & Detailed \\
\hline 14 & 16 & Advanced & Nanny(2) & Funny & $\mathrm{x}$ & $\begin{array}{l}\text { Unmarked/ } \\
\text { Irrelevant }\end{array}$ & Ridiculed & $\mathrm{x}$ & Detailed \\
\hline 15 & 16 & Advanced & Nanny(2) & $\begin{array}{l}\text { Funny ha- } \\
\text { ha }\end{array}$ & $\mathrm{x}$ & $\begin{array}{l}\text { Unmarked/ } \\
\text { Irrelevant }\end{array}$ & $\mathrm{x}$ & $\mathrm{x}$ & Superficial \\
\hline 16 & 16 & Advanced & Nanny(1) & Funny & $\mathrm{x}$ & $\begin{array}{l}\text { Marked/ } \\
\text { Relevant }\end{array}$ & Ridiculed & $\mathrm{x}$ & Detailed \\
\hline 17 & 16 & Advanced & Nanny(1) & Funny & $\mathrm{x}$ & $\begin{array}{l}\text { Unmarked/ } \\
\text { Irrelevant }\end{array}$ & $\mathrm{x}$ & $\mathrm{x}$ & Superficial \\
\hline 18 & 17 & Advanced & Rachel(1) & $\mathrm{x}$ & supported & $\mathrm{x}$ & $\mathrm{x}$ & $\mathrm{x}$ & Superficial \\
\hline 19 & 17 & Advanced & Nanny(2) & $\begin{array}{l}\text { Funny ha- } \\
\text { ha }\end{array}$ & $\mathrm{x}$ & $\begin{array}{l}\text { Marked/ } \\
\text { Relevant }\end{array}$ & Ridiculed & $\mathrm{x}$ & Detailed \\
\hline 20 & 17 & Advanced & Nanny(2) & $\begin{array}{l}\text { Funny ha- } \\
\text { ha }\end{array}$ & $\mathrm{x}$ & $\begin{array}{l}\text { Unmarked/ } \\
\text { Irrelevant }\end{array}$ & $\mathrm{x}$ & $\mathrm{x}$ & Superficial \\
\hline \multicolumn{10}{|c|}{ Nanny $(*)=*$ position in which the film was show, (1) first (2) in relation to the other. } \\
\hline
\end{tabular}

The scene with the male nanny was reported to have been quite funny, or at least funnier than the other one. That did not come as a surprise because it had been foreseen by the analysis of the SDS as for how funny they had found the scenes. Tables R.7 and R.14 clearly indicate that the Male Nanny scene had mean values above four for both male and female students, while the scene in which Ross and Rachel stay together the mean values lingered a bit below that, slightly leaning towards the neutral point, however high it still was (3.95 for both boys and girls).

As for a more detailed account of the findings, a disclaimer is important reminding to bear in mind that the categorization was devised based on students answers and therefore some of them came from the same student and some from several different ones which will affect the total number of students per category, as on all Tables from R.25 to R.30 below.

Among those who actually chose the scene in which Ross and Rachel stay together, four of them were girls and there was only one boy, which was stereotypically expected because although it was a rather sexist plot, it was still what the general public buys as 
"romantic", especially for sitcom fans that would also see it as long-awaited. The girls were all supportive of this stereotype of a romantic relationship - in which the couple stays together no matter at what cost to the woman - and the only boy who chose it was indifferent to the stereotype, focusing on other things in the episode so as to render it funny/memorable. There was one girl who actually pointed out the stereotype on the scene but she was so annoyed by it that she actually chose the other scene as her favorite exactly because of it. Examples from students can be found on table R.25 below.

Table R.25

\begin{tabular}{|c|c|c|c|l|l|}
\hline $\begin{array}{c}\text { GENDER } \\
\text { BIAS }\end{array}$ & \multicolumn{2}{|c|}{ Stereotype } & \multicolumn{1}{c|}{ EXAMPLES } \\
\hline Students & Sup. & Ig. & Quest. & (not all examples have been included) \\
\hline MALE & $\mathrm{x}$ & 1 & $\mathrm{x}$ & No explicit comments were made. \\
\hline FEMALE & 4 & 1 & 1 & $\begin{array}{l}\text { Supportive: "[funny] when Ross tries to convince Rachel's old boss to hire } \\
\text { her again" "romantic storyline" "get their "happily ever after" } \\
\text { "finally...happy ending" } \\
\text { Ignored: "unusual and dynamic" (stereotypical scene) }\end{array}$ \\
\hline
\end{tabular}

Still among the girls who preferred Ross and Rachel's scene, 50\% remembered details of the scene and one of them seemed to find it unusual without explaining very much why she thought so. This evaluation was rather peculiar because the least thing expected about this scene was the mentioning of any unpredictability trait. One of the premises for choosing the scene was exactly the fact it showed a rather cliché, gender biased take on how relationships should develop when it is time to take different paths. As her account was very superficial, it was not possible to investigate any further what had happened on the scene that might have influenced her judgment.

Specifically among those who noticed the stereotype in the scene, most of them supported it (three girls) and the other boy and girl completely ignored it. Naturally, the girl mentioned before who questioned the stereotype was not among those who chose the scene as their favorite In terms of Critical Thinking, she raised a question concerning the way Ross gets what he wants - by boycotting Rachel - and showed awareness of gender bias, as the examples on table R.26 show. 
Table R.26

\begin{tabular}{|c|c|c|c|c|}
\hline $\begin{array}{c}\text { GENDER } \\
\text { BIAS }\end{array}$ & \multicolumn{3}{|c|}{ Awareness } & EXAMPLES \\
\hline Students & Crit. & Prej. & Un. & (not all examples have been included) \\
\hline MALE & 2 & 0 & 5 & $\begin{array}{l}\text { Critical: "It also made me think "why shouldn't guy be a nanny?"; "Ross and } \\
\text { Joey couldn't find an example (at least a good one) of a profession a woman } \\
\text { shouldn't have. I believe they feared being sexist."; "Interesting how some } \\
\text { men can be very insecure about their masculinity"; "In the end he stays very } \\
\text { emotive because his father reprehended him". } \\
\text { Prejudist: No explicit comments were made. } \\
\text { Unusual: "unexpected"; "surprising"; "more original"; "the end was quite } \\
\text { unexpected as Ross cried like a baby"; "not as predictable as the other"; } \\
\text { "incredibly surprising because Ross ends up doing exactly what he } \\
\text { complains about"; "not as predictable" }\end{array}$ \\
\hline \multirow[t]{2}{*}{ FEMALE } & \multirow[t]{2}{*}{1} & \multirow[t]{2}{*}{4} & \multirow[t]{2}{*}{3} & $\begin{array}{l}\text { Critical: "I don't like how Ross begs her to leave her dreams behind to stay } \\
\text { w/ him" } \\
\begin{array}{l}\text { Prejudist: "funny because he was kind of gay"; "Ross' remarks related to the } \\
\text { nanny made me laugh"; "[funny] to do very sensitive with things only girls } \\
\text { would be" ;"funny when he cried like a girl" }\end{array}\end{array}$ \\
\hline & & & & Unusual: "I was more surprising"; "the other one was too cliché"; \\
\hline
\end{tabular}

Among the ones who showed critical thinking, two of them were boys and only one was a girl. The boys questioned the reasons why sensitivity is so weird in a guy and why a guy can't be a nanny. One of them actually mentioned he felt the characters in the scene were hesitant about making a gender biased comment in the scene because they may have "feared being sexist", explicitly highlighting the sexism. The girl was much more critical of the stereotypical ending given to Rachel and Ross mentioning she found it unfair and exposing the sexism in the scene, as table R.26 shows.

Unpredictability seems to have played a major role in students' choice, especially among the boys. Among those who expressed gender bias awareness in regard to how unusual the male nanny character and behavior was, five out of eight were boys who were pleasantly surprised by the originality of the situation (see Table R,26). Another good point was that one male student talked about the surprise at the end of the episode in regard to Ross, indicating he grasped the irony behind the story and who the joke was on as the plot questioned the stereotype of gender roles. It was amazing to see that among the boys, although they 
recognized the gender role inversion as uncommon, they did see it in a good light, as opposed to what happened among the girls.

It was really disappointing to realize that among the students who showed gender bias awareness, girls came across as much more judgmental in matters of gender than the boys. As seen on the examples on table R.26, $100 \%$ of the students who made explicitly prejudist comments in this category were girls who openly called the male nanny gay and pointed at his supposed femininity as a source of laughter, ridiculing the fact he was showing his emotions, as demonstrated by the next category on table R.27. Although the absolute number of female students who made such comments was not high, boys, on the other hand, seemed to have accepted Sandy's sensitivity much better, even criticizing contrary behavior.

Table R.27

\begin{tabular}{|c|c|c|c|}
\hline $\begin{array}{l}\text { GENDER } \\
\text { BIAS }\end{array}$ & \multicolumn{2}{|c|}{$\begin{array}{l}\text { Male } \\
\text { Emotions }\end{array}$} & EXAMPLES \\
\hline Students & Ridiculed & OK & (not all examples have been included) \\
\hline & & & $\begin{array}{l}\text { Ridiculed: "I laughed a lot when Ross started crying when he was talking to } \\
\text { the male nanny" }\end{array}$ \\
\hline MALE & 1 & 8 & $\begin{array}{l}\text { OK: "he ends up doing exactly what he complains of: crying with Sandy the } \\
\text { nanny"; "being male and sensitive" (as opposed to "but") ; "emotional guy } \\
\text { who just conquers everyone with his stories"; "the irony of Ross crying on } \\
\text { Sandy's shoulder" "so talented and sensitive" }\end{array}$ \\
\hline FEMALE & 7 & 0 & $\begin{array}{l}\text { Ridiculed: "the more his qualities and sensitivity were shown, the funnier the } \\
\text { episode got"; "[funny] because the nanny they hired was a really sensitive man } \\
\text { that used to cry a lot"; "when the male nanny cried it was really funny" } \\
\text { OK: No explicit comments were made. }\end{array}$ \\
\hline
\end{tabular}

As a consequence, male students' considerations about the male nanny were rather refreshing. In their discourse, many mentioned the fact the nanny was a not a woman, but not all of them thought that was relevant. An interesting fact regarding how they marked Sandy as a man in their discourse was that among those who highlighted it, the vast majority did not mention having been affected by it in a negative way, as examples on Table R.28 shows. What most boys did was indicate Sandy was a male nanny as they referred to him but they did not put any weight on it so as to how much it had influenced their choice for that scene or laughter. 
Besides that, it is important to observe that this time some girls were also more open minded in respect to Sandy, which was rather stimulating if compared with the previous categories (Tables R.26 and R.27) in which a few girls acted just like Ross in the episode, in a prejudist and disrespectful way, with many ridiculing Sandy, the male nanny, simply because he was "too sensitive" a man. According to those examples, male students really did regard Sandy's sensitivity as something normal and even positive and many of their female counterpartners had thought the opposite. This, though still noticeable, somehow translated a bit less substantially into their discourse, as seen on table R.28.

By investigating students discourse, it was still quite startling to realize that it was the female half of the participants that struggles more to get over the fact Sandy was not a "regular" nanny. $100 \%$ of the girls who marked the male nanny in their discourse perceived it as a relevant factor either for humorous purposes or memory trigger. They explicitly mentioned they laughed because of it, which agrees with the previous reading of how they ridiculed male emotions and sometimes even showed explicit prejudice, as mentioned previously and confirmed by examples on tables R.24 - R.28.

Table R.28

\begin{tabular}{|c|c|c|c|c|}
\hline $\begin{array}{l}\text { GENDER } \\
\text { BIAS }\end{array}$ & \multicolumn{3}{|c|}{ Role Inversion } & EXAMPLES \\
\hline Students & $\begin{array}{c}\text { Marked } \\
\text { Relev. }\end{array}$ & $\begin{array}{c}\text { Marked } \\
\text { Irrelev. }\end{array}$ & $\begin{array}{l}\text { Unmark. } \\
\text { Irrelev. }\end{array}$ & (not all examples have been included) \\
\hline MALE & 2 & 5 & 6 & $\begin{array}{l}\text { Marked/Relevant: "doing things that were not considered a "man } \\
\text { thing"; "it made the scene more watchable" (whatever this means) } \\
\text { Marked/Irrelevant: "a random emotional guy"; "why shouldn't a } \\
\text { guy be a nanny after all?"; "very funny scenes with Joey and the } \\
\text { male nanny; "Ross was talking to the male nanny"; "male } \\
\text { nanny...the scene was very laid-back". } \\
\text { Unmarked/Irrelevant: "the nanny was talking to Rachel"; "Ross's } \\
\text { problem with the nanny"; "Sandy was qualified" }\end{array}$ \\
\hline FEMALE & 10 & 0 & 7 & $\begin{array}{l}\text { Marked/Relevant: "the nanny was actually a man and a sensitive } \\
\text { one"; } \\
\text { "unusual seeing a male nanny"; "when the male nanny cried it was } \\
\text { really funny"; "the male nanny made the plot very funny" } \\
\text { Marked/Irrelevant: No explicit comments were made } \\
\text { Unmarked/Irrelevant:“[funny]Joey playing with Sandy's puppets"; } \\
\text { "the nanny" "Sandy" }\end{array}$ \\
\hline
\end{tabular}


Along these lines, female students tended to show their judgment on her word choices just as well. They used very negative words associated with the male nanny, as the examples on table R.27 show and really made a connection between how funny/entertaining it was for them and the fact the guy was so "feminine".

Conversely, most boys who marked the gender role inversion in their discourse with expressions such as "male nanny" or "a nanny who was a guy" did not make explicit reference to it when justifying their laughs. They sometimes even dismissed the fact the guy was perceived as "too sensitive" and openly referred to male emotions as being normal, registering the reasons for them to find the scene funny did not lie in that aspect of the scene, but in other facets of the plot such as the irony of having Ross ridiculed (see table R.29).

Table R.29

\begin{tabular}{|c|c|c|c|c|c|}
\hline \multirow{2}{*}{$\begin{array}{l}\text { HUMOR } \\
\text { Students }\end{array}$} & \multicolumn{4}{|c|}{ How funny was it? } & \multirow{2}{*}{\begin{tabular}{|l} 
EXAMPLES \\
(not all examples have been included)
\end{tabular}} \\
\hline & Funny & Ironic & $\begin{array}{c}\text { Funny ha- } \\
\text { ha }\end{array}$ & Fun & \\
\hline MALE & 9 & 2 & 2 & 0 & $\begin{array}{l}\text { Funny: "it was really funny"; "because it was funny"; "so } \\
\text { funny"; } \\
\text { Ironic: "Ross ends up doing exactly what he complains of: } \\
\text { crying with Sandy."; 'the irony of Ross crying on Sandy's } \\
\text { shoulder" } \\
\text { Funny ha-ha: "I laughed a lot", "it made me laugh" } \\
\text { Fun: No explicit comments were made }\end{array}$ \\
\hline FEMALE & 8 & 0 & 8 & 1 & $\begin{array}{l}\text { Funny: "When the male nanny cried it was really funny" } \\
\text { Ironic: No explicit comments were made. } \\
\text { Funny ha-ha: "I laughed when the nanny played the flute" } \\
\text { Fun: "It was really entertaining"; "enjoyable" }\end{array}$ \\
\hline
\end{tabular}

Another thought-provoking aspect when observing this second part of the analysis was the correlation between how funny students thought the scene with the male nanny was and their perception of the play on gender roles and common stereotypical expectations toward masculine behavior. This time it was even more intriguing the comparison between the two groups as boys' and girls' points of view were not quite as stereotypical as one might have predicted. In relation to the other scene, it was also interesting to see how male and female students related to the stereotype projected there. 
In terms of humor, most boys and girls found the scene with the male nanny funny indeed. Half the girls (10) found it funny and 8 of them actually mentioned laughing at it. Only one girl thought it was entertaining rather than funny, as indicated on table R.29 above. As the data on the previous table (R.24) shows, only 3 did not mention if they found it funny at all.

Among the boys, 9 out of 17 justified their preference for the scene by saying it was funny and oddly enough the two youngest boys, both 13 years old, mentioned the irony behind Ross's breakdown in the Male Nanny scene while all the other students, male or female, ignored this aspect of the scene. As noted by the SDS analysis which concluded boys were not as entertained by the scenes as girls, even when they did enjoy themselves, only two boys mentioned laughing out loud and only one mentioned he had found it quite enjoyable, which may not be representative of "funny" per se. Four male students did not mention any of these categories as they focused on other aspects of the scenes to justify their predilection.

Finally, in terms of how much they remembered the scenes, girls seemed to use fewer details than boys and only $50 \%$ t of them actually remembered enough to make explicit comments and connections, as opposed to $60 \%$ of the boys.

Table R.30

\begin{tabular}{|c|c|c|c|} 
MEMORY & \multicolumn{3}{|l|}{ How was their account? } \\
\hline Students & Superficial & Detailed & Unrelated Detail \\
\hline MALE & 9 & 6 & 2 \\
\hline FEMALE & 10 & 10 & 0 \\
\hline
\end{tabular}

All in all, the scenes seem to have had quite an impact on students as most of them actually remembered details they had seen.

Under a pessimistic guise, what is so striking about the answers reported in this section is that they seem to indicate that boys and girls were more critical of what resonates with their own group. Male students seem to have sympathized with Sandy and his high level of sensitivity, while female students were rather unforgiving, for instance. Another example was Rachel's stereotypical behavior which went almost unnoticed by male and female students, with very few actually criticizing it. 
This may have happened for many reasons which cannot and will not be attempted to be answered by this specific research. One can only speculate under a much broader perspective in terms of gender issues. Preconceived ideas of gender roles and representations are so deeply rooted in ourselves that the teenagers who participated the experiment could act nothing but biased while watching the scenes, hence girls with no sympathy toward the male nanny and boys not even recognizing the problem with the stereotypical expectation toward the woman in the relationship portrayed in the least chosen scene.

On the other hand, in a rather optimistic view, there is the realization that some boys and girls did leave the experiment questioning some concepts and preconceived ideas, which means it did foster critical thinking and that there is definitely room for exploring this in the ESL/EFL class. Besides that, even though girls were a bit harsher in their comments, it became clear that this kind of activity may give teachers something substantial to work from when confronted with delicate issues and their students' positions regarding them, but this will be specifically dealt with in the conclusion section. 


\section{CONCLUSION}

The aim of this research was not to understand the reasons behind students' choice while expressing their feelings in regard to the observation of gender bias or lack thereof in the scenes they were exposed to. The objective of this analysis was to pragmatically observe what these feelings were and understand how students perceive aspects of the underlying gender biased ideology present in the humorous acts, like sitcoms, that are being put to use in ESL/EFL classrooms and evaluate the need for ESL/EFL teachers to mindfully make use of them in an attempt to develop critical thinking toward this matter within and beyond the thresholds of the classroom.

In this light, after analyzing the data from the SDS, where students marked their feelings towards the scenes in relation to aspects of humor, gender bias and entertainment, and after collecting their preferences regarding the two very different plots they had been presented with, it became clear that in fact students in general are not really aware of the stereotypes and the hidden ideological agenda concerning gender issues. Very few students were able to critically perceive the gender biased aspect of the plots and many of them actually condoned the stereotypical gender roles and representativeness, which may be, among other things, a mere symptom of how ideologically bound they are regarding this aspect of our social life. On the other hand, it was obvious that many students already flirt with such exercise of analyzing and thinking beyond what they see, drawing from intertextuality and their own previous knowledge to judge and form an opinion about what they have been exposed to.

As this analysis shows, there are still a lot of misconceptions as to what is meant to be funny about gender representation and what should be questioned. The scene students chose as their favorite, for example, depicted a search for a nanny performed by the most famous couple in the sitcom F.R.I.E.N.D.S., Ross and Rachel, and how they had been ever so lucky to find a skillful, qualified, talented and sensitive male nanny. The only drawback working against him was exactly the fact he was a heterosexual man. As much as some students did point out the peculiarity of the scene and did not seem to be bothered by the male nanny's characteristics, many of them seem to have found the mere fact of having a man who 
is sensitive quite amusing.

Yet on a more positive note, some students seemed not to be interested at all in the nanny's gender and really enjoyed seeing Ross struggle with his own incoherence when trying to find flaws to dismiss the nanny. Two very young male students even pointed out explicitly the irony of the situation, which leads to the belief that the problematization of the sexism in the scene might as well be explored in order to reveal what the real issue is when it comes to gender roles. Others also criticized the other scene with the stereotypically romantic plot, claiming it was "too predictable" and "too cliché", as indeed it was.

Another point to be observed was how assumptions made by ESL/EFL teachers regarding students' perception can be completely off at times. Oddly enough, for instance, the survey showed that the acceptance of male emotions as something legitimate is still far from being naturalized, specially by teenage girls, who seemed to have had more difficulty coming to terms with the male nanny behavior without labeling him less of a man (e.g. "gay" or "like a girl"). Not only was the stereotypical expectation that boys would feel uncomfortable completely wrong, but it was also challenged by the fact girls really did feel so about how the male sex was being represented, This makes out for a good exercise in reflection for the ESL/EFL teacher, in order to question their own preconceived ideas and stereotypical assumptions, and allow room for students to express themselves so the ESL/EFL classroom can provide a truly welcoming environment for meaningful discussions and thus meaningful learning.

As for how much students remembered the scene, it was demonstrated that students do remember what they are exposed to and even when they do not remember facts, they tend to remember the feelings the activity aroused in them. It goes without saying that in order to make the work on critical thinking meaningful it is cardinal to have students not only reflect upon issues while being confronted with them but also past this moment, when they take within them the unfolding of their own findings and observations. Therefore, remembering the scenes, the plots and how they felt was an important aspect in understanding how suitable such resources are for the ESL/EFL teacher to work beyond language and it has certainly been acknowledge that, in fact, they can really work in such way.

The research results also corroborate the idea that humor does work as a platform for discussing more difficult topics and broader issues since it definitely played a role in helping students remember what they had seen. As mentioned above, discussing critical issues such as the one proposed in this study can only happen if students are involved and in tune with what 
they have been exposed to. The fact they described the scenes as funny and entertaining and gave details mainly concerning what made them laugh indicates that with humorous acts it becomes easier to have students relaxed yet connected to what they have seen, creating a rather appropriate environment to carry on deeper discussions.

In summary, the scenes proposed in the experiment did have an impact on students as most of them, male and female, did remember what they had seen and actually found them funny and entertaining enough to have caught their attention to the plots. Even though boys and girls tended not to quite grasp all the implications gender bias had on the development of the storylines, some students did highlight some problems and most were ready to actually face some more challenging questioning. Moreover, ESL/EFL teachers must also be confronted with their own misconceptions regarding gender issues and gender bias as expectations towards male students' and female students' also had to be revised and rethought after analyzing the results.

As a consequence, when wishing to explore critical thinking in the ESL/EFL classroom, ESL/EFL teachers urge to do so not by teaching what students should think but by questioning and confronting students with their own assertions, which can be drawn from the same media used to explore language while they are doing their regular activities if taken into consideration how students will actually remember and embrace the topic raised by the plot in question. As not all students think alike, and especially not all male students or female students among themselves, the exchange brought by their sharing their views will surely shed a light on the understanding and the perception of gender issues by students and teachers. Bearing this in mind, the ESL/EFL teacher must be prepared to work from students' perceptions so as to create the right environment and clear agenda in order to foster critical thinking and, thus, meaningful experiences within the limits of the classroom and beyond.

In conclusion, what became clear with this analysis is that ESL/EFL teachers must be critical while they themselves are choosing what to present students with, choosing carefully and mindfully what they are bringing to class. As for gender bias issues of representation and gender role, ESL/EFL teachers should really reflect upon the unfolding of a certain topic and what kind of questions it will help discuss or deepen, specifically in terms of gender ideology. ESL/EFL teachers willing to foster critical thinking among their teenage students should understand the possibilities in media resources used in class and try to remember that students' awareness of such controversial issues is the exception and not the rule, but latent is the potential they have to develop the skill of critically observing the world around them. 


\section{BIBLIOGRAPHY}

AL-HINDAWE, J (1996) Considerations When Constructing a Semantic Differential Scale. School of Communication, Arts and Critical Enquiry. Publisher: Bundoora, Victoria: Linguistics Program, La Trobe University, ISSN 1036-0808, In: La Trobe working papers in linguistics, Volume 9. Available at: http://goo.gl/Fc9Iob Downloaded in January 2014.

ARVIDSSON, S (2009) A Gender Based Adjectival Study of Women's and Men's Magazines. Essay. Department of Humanities and Social Sciences. Gävle, Sweden: Gävle University College. Available at: http://goo.gl/T3grMR Downloaded in January 2014.

BELL, C M and McCARTHY, P M. and McNAMARA, D S (2006) Variety in Language Use Across Gender: Biological versus Sociological Theories. Memphis/TN. Available at: http://goo.gl/uZ0cj1 Downloaded in January 201.

FINEGAN, E (2008) The Language Varieties of Women and Men. In: Language Its Structure and Use. Chapter 11 Language Variation Among Social Groups: Dialects - pp377379. Available at:

http://goo.gl/At8Sxx Downloaded in January 2014.

GEE, J P (1999). An introduction to discourse analysis theory and method (2nd ed.). New York: Routledge.

GILLILAND, H \& MAURITSEN, H (1971) Humor in The Classroom. In: The Reading Teacher. Vol. 24 (8) p.753-756, 761;

LAKOFF, R (1973) Language and Woman's Place. In: Language and Society, Vol. 2, No. 1. pp. 45-80. Cambridge: Cambridge University Press.

LEMKE, J. Textual Politics: Discourse and Social Dynamic. London, England: Longman, 1995.

MILLS, S (2005) Feminist Stylistics. London: Routledge. 
PERCEC, D (2008) Exploring Gender Differences in verbal and nonverbal interactions: the feminist critique of language approach. In: Professional Communication and Translation Studies. Timi $\square$ oara, Romania: West University of Timisoara. Available at: http://goo.gl/S4OTCl Downloaded in January 2014.

SUNDERLAND, J (2006) Language and Gender - An Advanced Resource Book. New York: Routledge.

TANNEN, D (1990) You Just Don't Understand: Women and Men in Conversation. New York: Ballantine Books.

WANZER, M (2002) The Good, the Bad and the Not-So-Funny Things That Teachers Say and Do. In: CHESEBRO, J. L. \& McCROSKEY, J. C. (2002) Communication for Teachers. Section 2: Our teaching behavior Chapter 10 Use of Humor in the Classroom pp116-126. Canisius College. Boston: Allyn and Bacon. Available at: http://goo.gl/FhzlNk Downloaded in January 2014.

ZYNGIER, HAKELMULDER and VAN PEER (2007) Muses and Measures: Empirical Research Methods for the Humanities. Cambridge: Cambridge Scholars Publishing.

\section{Websites:}

The f word - http://goo.gl/gzsMW4

Feminist media - http://goo.gl/Wyk3Pv

Feminist fiction - http://goo.gl/WZd01w

Maybe genius - http://goo.gl/6kSGBL

Feministing.com - http://goo.gl/R4q1Yh

T.SHE Unpacking Television from a Feminist Perspective http://goo.gl/2ryKKZ

Dr she bloggo - http://goo.gl/A0LmpF

Theorizing masculinity http://goo.gl/RZm7DR 